BOOKS FOR THE GOUNTRY.
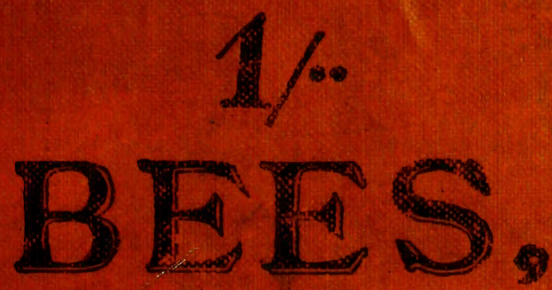

TXXXIXI.

\title{
RABITS, MANAGEMEN工
}

AND TKEATIET!

\section{BT THE, \\ REV. I. G. hioOs,}

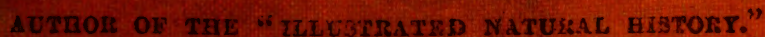

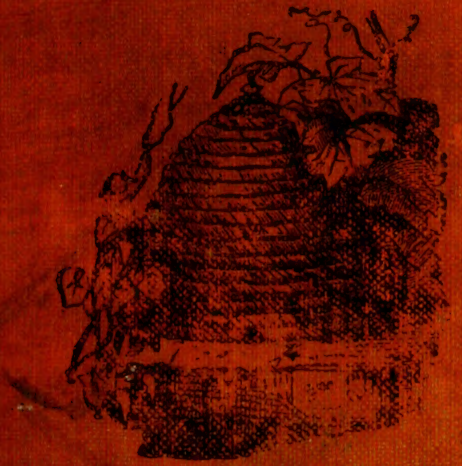

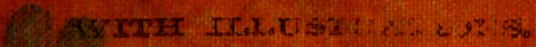

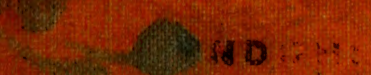

GHORCE ROWEL

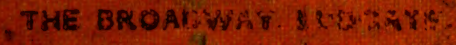

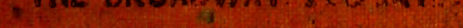

565. 


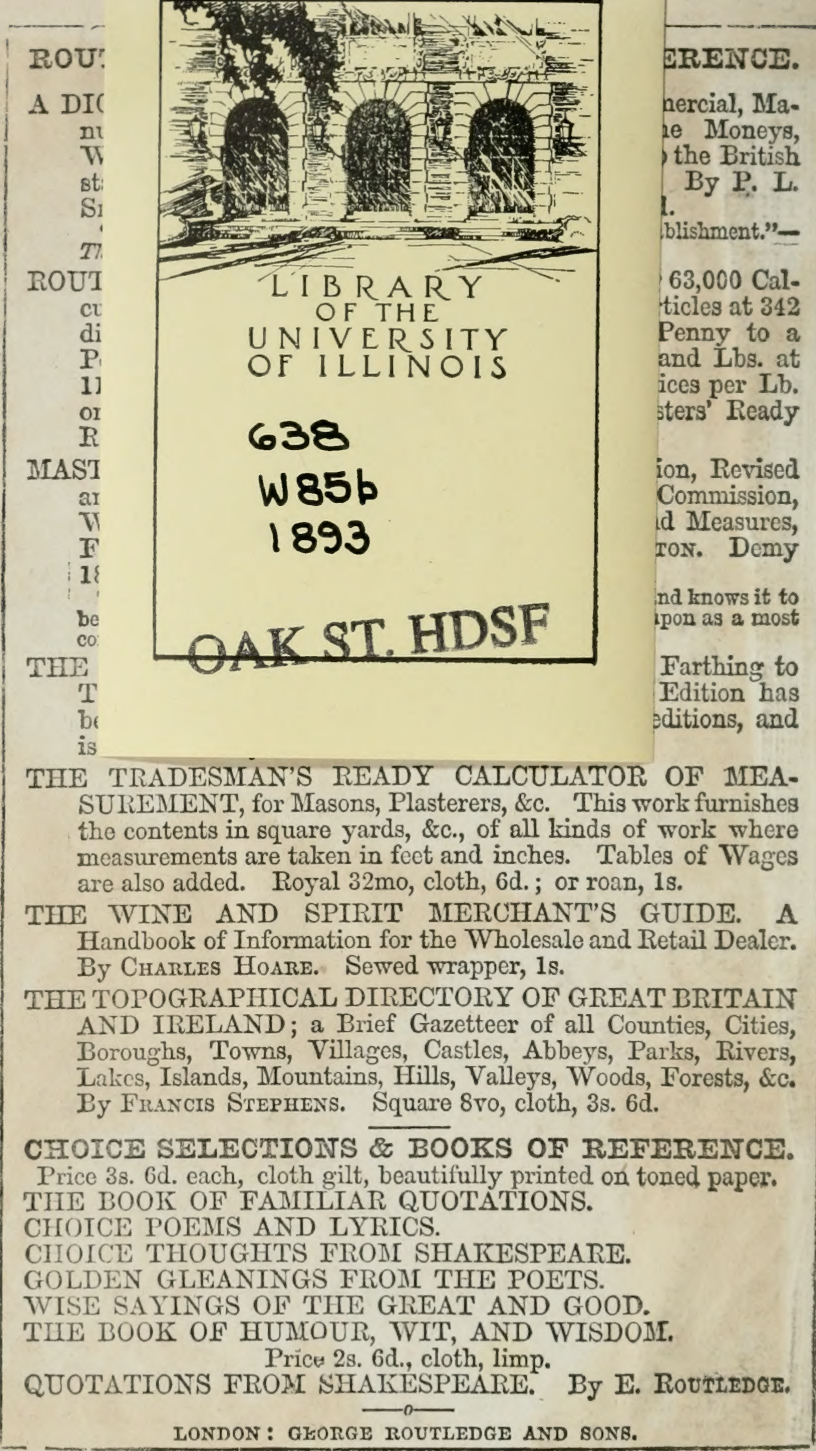


In post 8 vo. toned paper, green cloth, price $3 \mathrm{~s}$. $6 \mathrm{~d}$. each; bevelled boards, gilt edges, $5 \mathrm{~s}$; half calf, $6 \mathrm{~s}$. $6 \mathrm{~d}$. ; full calf or morocco,

9s. ; tree calf, gilt edges, $10 \mathrm{~s} .6 \mathrm{~d}$.

THE ARABIAN NIGHTS.

THE ADVENTURES OF DON QUIXOTE.

THE ADVENTURES OF GIL BLAS.

D'ISRAELI'S CURIOSITIES OF LITERATURE.

A THOUSAND AND ONE GEMS OF BRITISH POETRY.

Edited by Dr. MACKAY.

THE BLACKFRIARS SHAKESPEARE. Edited by C. KNIGHT. CRUDEN'S CONCORDANCE TO THE OLD AND NEW TESTAMENT.

BOSWELL'S LIFE OF DR. JOHNSON.

ROUTLEDGE'S NEW DICTIONARY.

W. H. PRESCOTT'S HISTORIES.

IIISTORY OF THE REIGN OF FERDINAND AND ISABELLA. 2 vols. (4s.)

HISTORY OF THE CONQUEST OF MEXICO. 2 vols. (4s.) HISTORY OF THE CONQUEST OF PERU. 2 vols. (4s.) HISTORY OF PHILIP THE SECOND OF SPAIN. 3 vols. (6s.) HISTORY OF THE REIGN OF CHARLES V. OF SPAIN. 2 vols. (4s.)

BIOGRAPHICAL AND CRITICAL ESSAYS. (2s.)

ROUTLEDGE'S MINIATURE IIBRART. Cloth, gilt edges, price 6d. each.

THE LANGUAGE OF FLOWERS.

ETIQUETTE FOR GENTLEMEN.

ETIQUETTE FOR LADIES.

THE BALL-ROOM MANUAL.

ETIQUETTE OF COURTSHIP AND MATRIMONY.

TOASTS AND SENTIMENTS.

HANDBOOK OF CARVING.

DRESS.

ROUTIEDGE'S EDUCATIONAT IIANUATS. 64 pages each, boards, price $6 \mathrm{~d}$. each.

COMMON THINGS; or Notes IMMMALIA. By the Rev. J. on Familiar Objects.

THE FIVE BOOKS of MOSES. GENERAL GEOGRAPHY OF FIRST BOOK OF EUCLID GERMAN SCHOLAR'S HANDBOOK. G. WooD. THE WORLD. ARITHMETICAL AND GEO. GRAPHICAL TABLES.

Price 1s. each, boards.

A HANDBOOK OF ENGLISH PROSE and DRAMATIC LITERATURE. By W. G. LARKINS.

A HANDBOOK OF ENGLISH POETIC LITERATURE. By W. G. LaRKins. THE COMIO RECITER. 


\section{ROUTLEDGE'S DICTIONARIES.}

THE NEW ENGLISH DICTIONARY.-In crown 8vo, cloth, price 3s. 6 d.

ROUTLEDGES' PRONOUNCING DICTIONARY. Founded on Walker, Worcester, Craig, and others; and enriched with many Thousand Modern words connected with Literature, Science, and Art. Edited by Dr. NuTtaLL. In one handy volume, printed in a new clear type, neatly bound.

In royal 8vo, 2 vols., cloth, price £2. $2 \mathrm{~s}$.

CRAIG'S UNIVERSAL, TECHNOLOGICAL, ETYMOLOGICAL, and PRONOUNCING DICTIONARY of the ENGLISH LANGUAGE, embracing all the terms used in Art, Science, Literature. New Edition, revised by Dr. NutraLL, with Appendix of New Words.

In royal $8 \mathrm{vo}$, cloth (1,300 pages), price $12 \mathrm{~s}$.

WEBSTER'S DICTIONARY of the ENGLISH LANGUAGE, exhibiting the Origin, Orthography, Pronunciation, and Definition of Words; to which are added, a Synopsis of Words differently pronounced by different Orthoepists, Walker's Key to the Classical Pronunciations of Greek, Latin and Scripture Proper Names, and a Vocabulary of Modern Geographical Names, with their Pronunciation. Tenth Edition, revised and corrected.

In medium 8vo (980 pages), cloth, price 12s.

WEBSTER and WORCESTER'S NEW UNIVERSAT, CRITICAT and PRONOUNCING DICTIONARY of the ENGLISH LANGUAGE, with Waller's Key to the Pronunciation of Classical and Scripture Proper Names, a Pronouncing Vocabulary of Modern Geographical Names, and an English Grammar.

In royal $8 \mathrm{vo}$, price $7 \mathrm{~s} .6 \mathrm{~d}$.

KNOWLES' PRONOUNCING DICTIONARY of the ENGLISH LANGUAGE, incorporating the labours of Sheridan and Walker, with 50,000 additional words, and a Key to the Pronunciation of Classical and Scripture Proper Names. Ninth Edition, revised.

In fcap. 8 vo, boards (256 pages), price 1s. ; or roan, 1s. $6 \mathrm{~d}$.

WATKER'S PRONOUNCING DICTIONARY, with the Accentuation, Orthography, and Pronunciation of the English Language distinctly shown, according to the best authorities; to which is added, An Introduction to the English Grammar, the Pronunciation of the most important European Languages, a Chronological Table, and a variety of useful information. 122nd Thousand.

In demy $18 \mathrm{mo}$, boards (288 pages), price $1 \mathrm{~s}$.

JOHNSON'S DIC'TIONARY of the ENGLISH LANGUAGE. A New Edition, adapted to the present state of English Literature. By P. Austrin Nuxtal,, IL.D.

In demy $18 \mathrm{mo}$, cloth, price $1 \mathrm{~s} .6 \mathrm{~d}$.

THE SCHOOL EDITION Of JOHNSON'S DICTIONARY. A New Edition, adapted to the present state of English Literature, and comprehending the principal terms of Military Science, Geology, \&c., with a useful collection of Philological, Literary, and Historical Articles, intended for general reference.

In demy $18 \mathrm{mo}$, cloth (224 pages), price $1 \mathrm{~s}$.

JOINNSON'S DICTIONARY of the ENGLISH LANGUAGE, enlarged and modernized by P. Austin Nuttali, LL.D.

In $64 \mathrm{mo}$, cloth (632 pages), price 1s. ; roan, gilt edges, 1s. $6 \mathrm{~d}$. ; morocco, $2 \mathrm{~s}$.

ROUTLEDGE'S DIAMOND DICTIONARY of the ENGLISH LANGUAGE, adapted to the present state of English Literature; in which every word is defined with precision and brevity, and the Accentuation and Orthography clearly shown.

In roy. $32 \mathrm{mo}$, cl. ( 250 pp.), price 9 d.; roan, plain edges, $10 \mathrm{~d}$.; roan, gilt edges, $1 \mathrm{s.}$ JOHNSON'S DICTIONARY of the ENGLISH LANGUAGE, with Walker's Pronunciation of all the difficult or doubtful words, and marks to show where to double the consonant in the participle.

In $32 \mathrm{mo}$, cloth (200 pages), $8 \mathrm{~d}$.; roan, plain, $9 \mathrm{~d}$. ; roan, gilt edges, $1 \mathrm{s.}$

JOHNSON'S POCKET DICTIONARY of the ENGLISH LANGUAGE, improved by the addition of many thousand words.

In royal $18 \mathrm{mo}$, boards ( 200 pages), $1 \mathrm{~s}$.

WEDSTER'S PRONOUNCING DIOTIONARY Of the ENGLISH LANGUAGE. $-0$

LONDON: GEORGE ROUTLEDGE AND SONS. 
The person charging this material is responsible for its return to the library from which it was withdrawn on or before the Latest Date stamped below.

Theft, mutilation, and underlining of books are reasons for disciplinary action and may result in dismissal from the University.

To renew call Telephone Center, 333-8400 UNIVERSITY OF ILLINOIS LIBRARY AT URBANA-CHAMPAIGN

211987 
Price 1s. each, Boards, with Illustrations.

Pigkons and Rabits. By E. B. Dreameb. Thi Poultry Yard. By Miss E. Watts. Bris. By the Rev. J. G. Wood.

Thi Kitchre Gardik. By E. S. Drhamkr. The Flowbe Gabdri, By F. S. Delambr.

GEORGE ROUTLEDGE AND SONS, TIIE BBOADWAY, LUDGATB. 


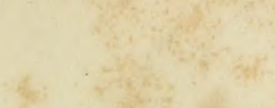

34 $x^{2}+2 x^{2}+4$

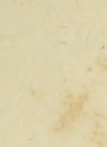

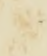

$x^{2}+2+2 y$ $x^{2}+9$

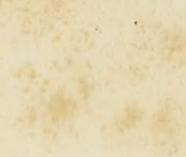

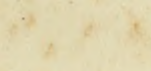

ax

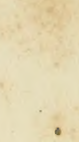

$\rightarrow \frac{2}{8}$

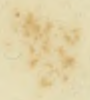

a

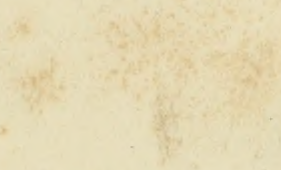

(n)

$$
x^{2}+2 \times+5
$$

$x+5$

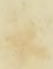




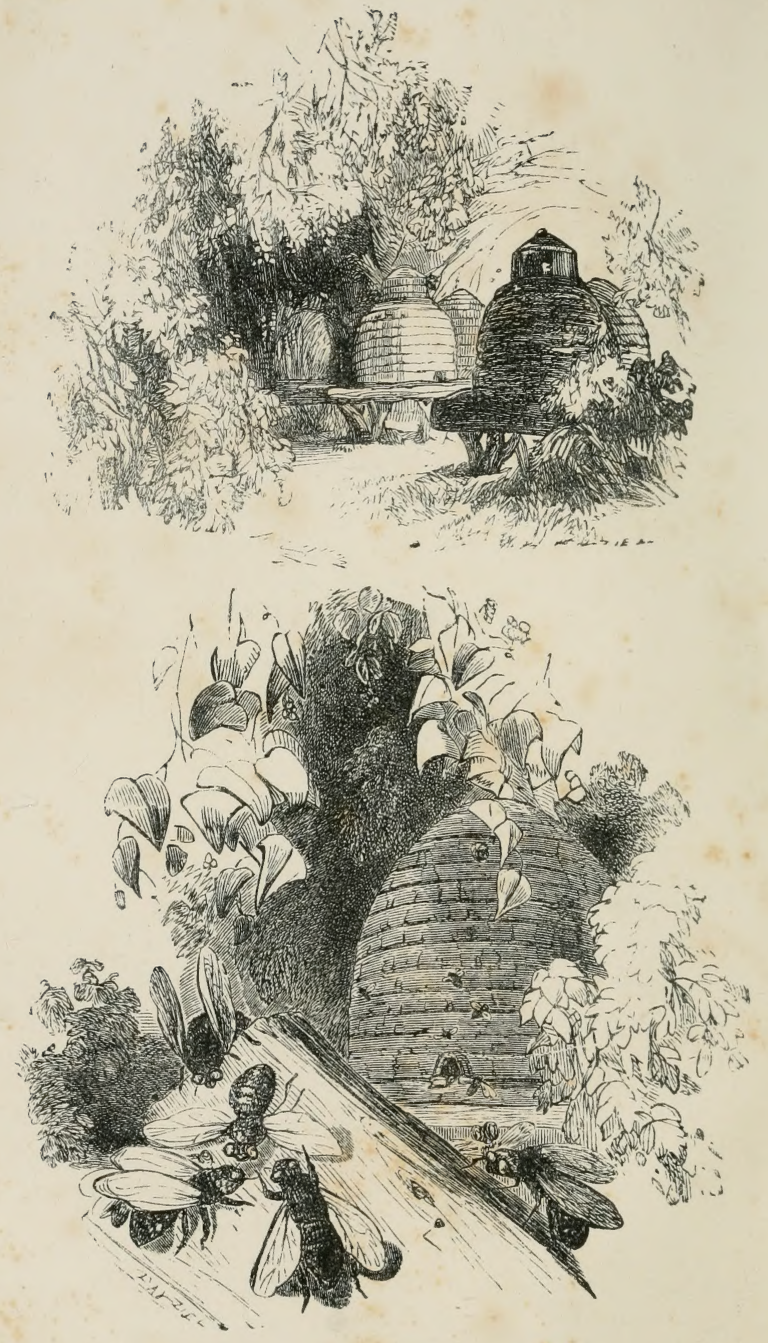

The Aprary. 


\section{B E E S ;}

THEIR

\section{HABITS, MANAGEMENT, AND TREATMENT.}

BY THE

\section{REV. J. G. WOOD,}

aUthor OF THE "Illustrated Natural history," ETC. ETC.

A 组cw Covition, with JEllustrations.

\section{LONDON :}

GEORGE ROUTLEDGE \& SONS,

THE BROADWAY, LUDGATE;

NEW YORK: 416, BROOME STREET. 



\section{B E E S.}

A sin the profound mysteries and inexhaustible profusion of life by which we are surrounded, and which only deepen and increase to our eyes, as science leads us further onwards(not to baffle our inquiries, but to strengthen, by disciplining, the minds of the inquirers) - amid all the various manifestations of the boundless power of God, there is not, probably, one individual subject fuller of interest alike to the practical, the popular, the scientific, or the poetical mind, than the natural history of the Honey-Bee. To men of business engaged in rural pursuits, there is the great question of profit to be considered; to those who look merely on the surface of things for amusement, there is the spectacle presented of an insect community, constituted under a regular government, and exhibiting various social phenomena, which are not the less attractive that they are but partially understood; the man of science sees involved in the life of bees some of the most perplexing but attractive problems that can possibly engage his attention within the wide circle of created being; whilst to all in whom the poetical or idealizing faculty exists, there is the additional interest derived in part from the habits of the bees themselves, and partly from the attention paid to them by the great human masters of " the art divine,' who, from the days of Virgil, down to those of Shakspeare and Milton, have loved them, ay, and understood them too in essentials, and have, in loving them, given the bees a new claim to the love and attention of all other men. The picture of a bee-kingdom, which Shakspeare has drawn in the following lines, has the precision of a 
naturalist, united to the fancy of a poet, and the wisdom of a philosopher :-

"So work the honey-bees,

Creatures that by a rule in nature teach

The art of order to a peopled kingdom.

They have a king, and officers of sorts,

Where some, like magistrates, correct at home.

Others, like merchants, venture trade abroad.

Others, like soldiers, arméd in their stings,

Make boot upon the summer's velvet buds;

Which pillage they with merry march bring home

To the tent royal of their emperor:

Who, busied in his majesties, surveys

The singing masons building roofs of gold;

The civil citizen kneading up thé honey;

The poor mechanic porters crowding in

Their heavy burthens at his narrow gate;

The sad-eyed justice, with his surly hum

Delivering o'er to executors' pale

The lazy, yawning drone."

For those who have imbibed a taste for examining the wonders of nature-who find their leisure hours better employed in searching into the mysteries of creation than in wasting them in frivolous, expensive, or it may be injurious amusements-for those whose minds are attuned to the poetry of nature's book-whose eyes are enabled to see-

"Sermons in stones, and good in everything,"

even in the nettle, the centipede, the scorpion, the toad (most maligned of animated beings), or even the dreaded cobra, or rattlesnake-there is no more interesting; more fascinating, or more really instructive branch of science than that which treats of the history and habits of insects. More particularly are they adapted for those whose active minds would fain take them to other lands, in order to increase their stock of knowledge, whilst adver'se circumstances chain their unwilling bodies at home. He who desires to see the lion, the elephant, or the giraffe, in the full enjoyment of their natural tastes, engaged in their natural pursuits, and following their natural instincts, must, like Gordon Cumming, the redoubtable lion-hunter, leave his native land, and spend years separated from his fellow men, in the depths of the African forest, or on the wastes of a burning desert. Does 
the enthusiastic ornithologist desire to study the habits of the humming bird, or the mocking bird? He must proceed to the new world, brave the terrors of the Atlantic, expose himself to the dangers of venomous reptiles, miasmatic swamps, or it may be to the chance of getting his interior ventilated by civilized revolver, or the anatomy of his brain displaced by savage tomahawk. Or does the energetic naturalist wish to see for himself the habits of the gigantic whale?-he must be costert to live for months in a peculiarly uncomfortable ship, to reside among icebergs at all events; if unsuccessful, to return as wise as he went, and if successful to his heart's desire, to find himself in every body's way during the chase, the capture, and the flensing, and from the moment that the huge carcass is made fast to the ship, to the time when he disembarks, to exist in an atmosphere of blubber, and, to borrow the phraseology of the Ancient Mariner-

"Blubber here, and blubber there, And blubber everywhere."

Let every one in whom the sense of smell is not utterly extinct, beware how he set foot in a whaler. Is he an icthyologist giving himself up to the study of fish in their native element? How many days in the year will he find adapted to his purpose; when the wind does not ruffle the surface, that must be bright and clear, in order that his eyes may penetrate into the vasty depths, and perceive the glittering creatures engaged in their instinctive tasks, or when the rain does not make the water irremediably muddy, or the snow and frost obscure the surface altogether?

For him whose tastes incline to the study of animated nature, no pursuit is better adapted than that of entomology, by which I mean practical entomology. Without attempting for one moment to decry the labours of the systematic entomologist, whose discriminating eye enables him to discover trifling points of difference marking out species, and by whose aid we are enabled to affix a certain name and position to that insect, which to the inhabitant of another country would be unrecognisable in our description, yet he who would see the full beauty of insect life, must live among insects, and with them. Here lies the superiority of this 
peculiar branch of natural history. Lions, tigers, elephants, giraffes, in dens, as we see them at the zoological grardens, give us very little idiea of what their demeanour would be in their native forests. Who could (unless he were a German) write a natural history of the hippopotamus from examination of the mild, affectionate, oily monster who waddles after his keeper, and would not hear of going to sleep unless his human companion slept by his side? Or who will say that the much enduring lions, or the slouching, lazy Polar bears, give much idea of the manners of those animals in their native haunts, where the lion stalks fearlessly, and with that majesty of deportment which want of fear always gives, or spring's like a thunderbolt on his prey, dashing the enormous giraffe to the ground; or where, amid everlasting ice and snow, the Polar bear glides through the water in chase of the seal, or from the ice cliff defies the armed men who approach? Animals to be studied properly must be studied in their natural states, and if the observer cannot go to them, he must bring them to him. This he cannot do with the larger animals, but he can with the insects. The space which would not suffice for a lion to turn in, will form a forest for a beetle, and any one who has a room to give up to insects, and a hand to execute, can draw round him colonies of almost every order of insect, exhibiting their instincts and habits, as perfectly as if they had been left in the fields. He must have a hand to execute, because, when he comes to the practical part of the business, he will find, that in order to make the artificial forest, brook, or earth, as like the original as possible in all its properties, some amount of handiwork is required, and if, like Davy's experimental philosopher, he cannot saw a plank with a gimlet, or bore a hole with a saw, woe be to his purse. With, however, some ingenuity in resource and workmanship, the study of insects may be pursued with scarcely any detriment to the pocket, and any one possessing a room, or what is still more valuable, a room and a yard, or the roof of a house, may make a magic circle within which he may gather an incredible amount of insects, some by bringing them from their native haunts, and others, by laying such irresistible inducements for them, that they come of their own accord. He may rear most valuable moths and buttertlie 
from the egg, and secure a large brood for the next year . he may keep a colony of those queer mole-crickets which; show such sport if poked at with a straw; he may transplant an entire nest of ant, wasp, or hornet, without the possibility of getting stung'; or at all events, he may, at a trifling expense, set up a few hives of another of the same order, of the common hive bee. These will, in fact, cost nothing; as, if the management be only passable, the produce of the hives will pay their cost in the first year, and all after that will be sheer gain. If, however, after long trial, the hives fail, let him not be discouraged, but try again, leaving no method untried to discover the cause of the former failures. There are few places where bees cannot find a subsistence. Even in the heart of large cities, men keep colonies of bees, who, although their honey is not always of the finest flavour, yet thrive very tolerably in their domiciles on the house-top or the garret window-sill. All who are acquainted with the usages of college society, would agree that a more unpropitious locality for a bee-hive could scarcely be found than in a college window, for bees have a peculiar objection to tobacco smoke, which seldom ceases to exist within the college walls, not to mention the pranks that would be played by the more juvenile members upon the unfortunate bees through the medium of a long pipe. Moreover, bees dislike loud and sudden noises. This taste of theirs is not likely to be gratified by the learners of the cornet-à-piston, post-horn, and other brazen instruments, which are usually played without intermission for several hours daily (like the court of the Flying Island, and with the same disregard for time), and subjected to occasional flourishes at any hour of the day or night. Then bees do not like strangers, of whom they must see plenty, if they reside in a college. Yet a colony of bees was kept, and successfully kept, in one of the colleges at Oxford. Their master is now a well-known apiarian, whose works on bee management have met with a well deserved reputation. For several years after he left colleg'e, the bee-stands and entrance-boards might be seen in the window, serving to remind the passer-by, that one man at least existed in the college, whose mind did not deem the study of insect life too triffing for the intellect of a human being. So let not the reader be deterred from the purchase 
of hives by the apparent unsuitableness of the locality. I am persuaded that if a strong stock were placed in the ball of St. Paul's Cathedral, they would get their living: For it is known that bees can fly three miles' distance in search of food, and bare would be the place indeed, where, within a circle of eighteen miles' circumference, a hive could not find food enough for its preservation. Even if they cannot do so, and supposing that they are kept more for the purpose of experiment and observation than for profit, they can be fed with sugar and beer, and will contrive to get both honey and was out of it. Nor let those fear whose very natural dread of stings has hitherto repelled them from the apparently dangerous pursuit of bee-keeping. It is perfectly possible so to arrange the hive, that while the observer can at his pleasure examine any part of the edifice, no bee can possibly reach him, unless the bee's sting is capable of penetrating through a barrier of wood and glass. The trouble, too, of keeping these most wonderful little insects is not nearly so great as is generally imagined. Only give them a fair start, and the less they are meddled with, the better for the bees. Put a good strong stock into the hive to begin with, and there will be little necessity to do anything with them except to take off well-glasses full of the finest wax and honey, and to substitute empty glasses; no very laborious task. Bees, like most other corporate bodies, have a great horror of interference from without, and always like to work their own reforms without the assistance of commissions from other quarters, and think that their own sovereign is quite capable of governing them without seeking the help of other powers. So the bee-master cannot meddle too little with the bees, and he must be a most particularly somnolent individual who would find the labour of attending to a few hives too much for him.

We are told that a bee-student of ancient times, Aristomachus, of Soli, in Cilicia, devoted nearly his whole time and thoughts to bees for sixty years; and that another, Philiscus the Thracian, spent his days regularly in the woods in order to investigate them in their natural condition.

These were evidently bee-enthusiasts. Among the more moderate $l$ ut earnest students of ancient times, may be briefly named, Aristotle, upon whose observations Virgil bas 
mainly based his fourth Georgic, Pliny, and Columella, who is esteemed the most accurate among these early observers. In modern times, the study appears to have assumed an altogether more definite and scientific shape in the hands of such men as Swammerdam, the unrivalled dissector of insect structures, Maraldi, the supposed inventor of glass hives, our own profoundly philosophic Ray, Reaurnur, Schirach, John Hunter, who first discovered the true origin of wax, and, above all, Huber, who is especially the high-priest of this particular altar in the great temple of science.

The various points necessary to be known by the wouldbe apiarian are briefly these:- First, whether or not it is worth while to keep bees at all. This is a question whick can best be answered by the kind of locality at his disposal, although, as I have before stated, the locality must be very poor indeed that will not feed one hive. Secondly, if he has decided upon keeping bees, where, when, and at what price, to procure them; how to establish them when procured; how to watch over and manage them when established; how to extract the greatest possible amount of honey from them without injuring the hive; how to dispose of his wax and honey when he has obtained them; what kind of hives to use for different purposes; how to increase the number of hives if required, and how to forward or prevent swarming. These points will be found explained in this little work, briefly and sparingly; briefly, because the limits of the book are too small to admit of long dissertations where a few sentences will suffice; and sparingly, because many of these points are much better learned by practice than by mere theoretical teaching: All that this little work pretends to perform is to put the reader in the way to work, and to serve, as far as a written book can do, as a guide if he should feel perplexed. In the present state of advancement in this particular department of natural history it is very probable that a future apiarian may be enabled to discover far better methods of management than those given here. The systems, however, that are recommended in this work have been found to work very successfully, and will very well serve until better are discovered. Nor can it be expected that any one who really takes an interest in the management will keep strictly to the rules 
laid down here, or in any other work whatever; fur he will be certain to find, as his experience increases, that he can make sundry variations from the principles on which he started, with great benefit to the prosperity of his insect colonies. The system that would answer admirably for an apiarium situated upon a hill surrounded with heather, would not be nearly so successful if the hives were placed in a sandy valley surrounded with thick woods, and plentifully watered by running streams. The rules, therefore, which are found here, may be taken only as a foundation for a building: which the architect may vary as he pleases, provided that the foundation is laid securely. If a man is not able to make these variations for himself, but perseveres dog'gedly in the fashion of his fathers, because it is the way he is used to, he need not put himself to the trouble of bee-keeping: at all, for he is not fit for it. Examples of this may be seen in almost every village in England where the inhabitants are wise enough to add hives to their agricultural stock. It is an everyday sight to see two cottage gardens merely divided from each other by a hedge, each carrying on beekeeping with very different success. In one the hives are numerous, and the busy thronging of the bees at the entrances proclaims their strength. On inquiry it is elicited that the hives have yielded many pounds of honey and wax, and are expected to yield much more, and yet be perfectly able to live through the winter without feeding; while in the other garden, the bees loiter about the entrances, goo off to their work, and return from it almost singly, and the deep hum of the drone is never heard. This is just because the one owner takes proper care of his bees, and the other neglects them. Many injure their bees either from neglect, because they are afraid of meddling with them, or by irritating them with needless interference. It is hoped that both these difficulties may be avoided by those who seek to g'ain a moderate knowledge of bee habits from these pages, for in most cases the bees die, swarms fail, and the honey is lost through the ignorance of the owner, and not through his wilful neglect. While, therefore, each man should learn to depend upon himself in the management of these insect kingdoms, he should not despise the instructions which be may gain from the experience of other's, and which, although 
It may not be implicitly followed, yet may serve as a guide in different straits. So, while each aspiring bee-master may fully intend to follow in the footsteps of the enterprising and accurate experimentalists mentioned above, he ought to take advantage of their experience, which will save him many an hour which might have been spent in endeavouring to elucidate a fact which has already been proved. The points already ascertained are as so many steps gained in the ascent to knowledge ; and it is our business not to endeavour to re-erect those steps, but, by taking our stand upon them, to strive by their aid to establish new ones.

We know not whether the inquiring spirit of Aristomachus or Philiscus exists among us at present, but certainly the name of those who aspire to teach the economy of beemanagement is legion. In Cotton's "My Bee-Book," there is a list of other people's bee-books, to the number of about one hundred and twenty-five distinct publications. One conclusion may, no doubt, be safely drawn from this facteither to the mind or to the pocket, the subject is found profitable. We trust to be able to show that it may be both to the readers of "Books for the Country." And as the knowledge of the natural habits of the bee is the only trustworthy foundation of the artificial ones we must, to sorne extent, impose upon them in servitude, let us begin with the former. We shall say little of the more technical points of the study of entomology; $*$ but merely state that the honey-bee is one of the genus Apis, and forms, with the other kinds of bees, of which there are several hundred in England alone, the order Hymenoptera.t We shall now request our readers to imagine themselves doing what they will find it very pleasant to do in reality, watching the chief operations of a hive through glass walls, with the aid of the most experienced eyes.

A swarm, led off by an old queen, has been just housed, in a warm and comfortable tenement, but it is empty-un-

- Derived from two Greek words, signifying to cut into, in illusion co the shape of insects, which are, as it were, cut into three distinct portions, the head, the thorax, or chest, and the abdomen, or belly. The word insect is derived from the Latin, and has the same mean. ing.

+ Derived from two Greek words, signifying membranous winged. 
provisioned. Everything has to be newly made : a giant task, but nobody understands better than bees the "philosophy of labour," and, as Gay singrs-

\section{"In the little bulk, a mighty soul appears."}

So while some go off to the fields to perform the labous allotted to them there, let us see what the other's are doing. in the hive. Some are clustering about the top; and now they fix themselves to the roof by the fore-leg:s, while the hinder-leg's hang down. Upon these other bees suspend themselves, and leave their legs similarly to the disposal of the new-comer, and thus a ladder is rapidly formed, reaching at last to the very bottom of the hive. To facilitate operations, and perhaps strengthen as well as elaborate their scaffolding, they also hang' themselves in festoons, each end attached to the roof; and before the actual commencement of labours, there is a series of such festoons formed, so that the bee-workmen may ascend and descend in every direction. The entire weight of this living staircase is borne by the individual bees at the top, and cheerfully borne too. Sydserff (reprinted in Cotton) says they will suffer their leg's to be disjointed before they will let go their hold. Such is the patriotism of the hive.

And now the bee-architect steps forth. Great bee! it is his glorious task to shape out the design of the first combs, and to lay, as it were, the first stone of the structure; tasks always performed by a single bee. The wax is secreted in the bodies of the bees, and appears under eight little flaps or pockets, on the under side of the abdomen. If a bee is examined carefully, these little receptacles are g'enerally found full of wax, and when the supply is complete, the edges of the wax-plate appear from under the pockets. When in this state, the wax-plate is five-sided, very thin, semi-transparent, and exceedingly brittle, and requires preparation by the bee before it is in a fit state to build combs with. If a bee is plunged into water, the scales of wax may easily be detached with the point of a needle; they will then rise to the surface of the water, and can be examined with ease, or they may be mounted as specimens to show the state of wax in its first secretion. Pollen has nothing to do with wax. Bees have been subjected to innumerable experiments when they 
have been deprived of pollen for several weeks, and have yet made combs, when fed only upon honey and water. In one case, they actually built combs when fed upon sugar and water only. The wax appears to be secreted principally when the bee is at rest. If combs are wanted in a hurry, a large number of bees, after filling their honey-bag's with honey, cluster together at the top of the hive, and remain there perfectly still for nearly twenty-four hours, by which means the wax is rapidly formed. In many cases swarms begin to build immediately after they have been settled in their new residence, and in this case the elaboration of was proves that it must have been formed during the previous state of inactivity. But he must have materials; and as his own stores are insufficient for such an undertaking, the obedient and industrious explorers of the country bring it to him in rapid and uninterrupted succession. Each mounts the ladder, extracts with its hind feet a plate of wax from under one of its eight scales (or pockets), where it was secreted, raises it to the rnouth, turns it round under the cutting' edge of the jaws (thus obtaining the effect of a lathe), and so the whole is divided into fragments. A frothy liquor is then formed on it from the tongue, and the mixture assumes the aspect of a plastic but tenacious substance, white and opaque. The whole mass being then repeatedly worked together by the teeth and tongue, is drawn out in the form of a narrow ribbon of white wax. After being again mashed together, and drawn out a second time in the opposite direction, it is then fit for building cells; and in that state is handed to the bee-architect, who at once commences the construction of the comb, while the labourer goes on with the preparation of the remainder of the scales, and then hurries off to collect fresh supplies. This labourer belongs to the wax-workers' class.

The architect commences his work: first, he constructs a block in the centre of and upon the roof, cf the shape here shown (a segment of a circle), and which measures nearly half an inch in length, about one-sixth of an inch in height, and only a twenty-fourth part of an inch in thickness.

All this while, another set of bee-artisans, the sculpturers, are waiting impatiently to begin. No sooner do they see room enough to introduce their somewhat smaller 
Fig. 1.

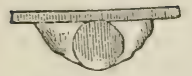

Front.
Fig. 2.

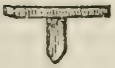

Side.
Fig. 3.

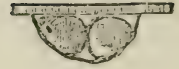

Back view.

'Tho front, side, and back views of the block on which the first excesva. tions for the cells are made.

Fig. 4.

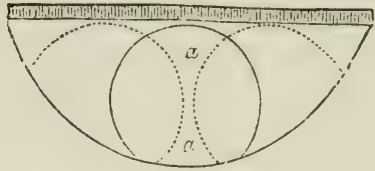

Front view magnified.

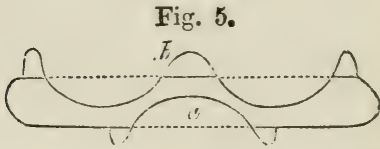

Transverse section through the same.

bodies between the wax-workers than they commence operations on the comparatively rude block thus prepared for them. One bee commences the architectural ornaments of the hive, by excavating a shallow, circular, basin-like hole in one side of the block of wax, adding. to the sides material which it has scraped out of the hollow. This is the first intimation of a cell. At the same time two other sculpturer-bees are hard at work upon the other side of the block, excavating similar hollows, which are so contrived that the point where they meet exactly coincides with the centre of the first cell upon the opposite side. By building upon this foundation, and by adding to the edges, a double series of cells are built closely adjoining to one another, and with their entrances opening opposite ways. The circular hollow upon Fig. 1, represents the 
first excavation, while the two hollows upon Fig. 3, show the two cells commenced upon the opposite side of the block. Fig. 2 merely shows the usual thickness of the first block. Now a wonderful change in the form of the cells takes place. Whether it be that instinct implanted in these insects forces them to act in a certain way, or whether it is that they have sufficient skill to direct themselves, we cannot tell. Up to this time the shape of the cells has been cylindrical, and if the block were cut through transversely, it would present the appearance given (much magnified) in Fig. 5, the centre of one cell exactly coinciding. with the junction of two cells upon the opposite side. In this shape, however, they remain no longer. The bees are aware that would cause an unnecessary expenditure of wax, decrease the available space of the hive, and probably interfere with that perfect ventilation, or at least purity of air, which they obtain by methods that surpass our skill to find out, much less rival. "From some eudiometrical experiments it has been ascertained that the air of a well-stocked hive is as pure as that by which it is surrounded."* So the bees, working to a perfect plan laid down for them by their architect, obtain a perfect result. By gradually cutting away all superfluous wax in the semicircles first formed, the walls become straight, and eventually the cells of two tiers present the aspect here shown:-

Fig. 6.

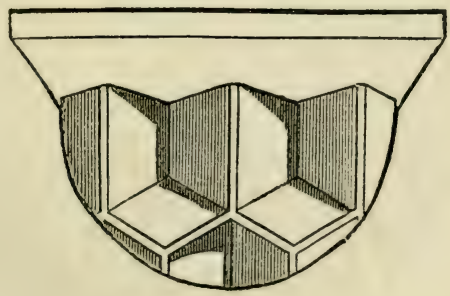

- Dr. Bevan's Honey-Bee. The best bee-book, on the whole, pub. lished in England. 
It will be seen that the back cells must necessarily be of the same shape to fit exactly into these, and the same with those below. Every wall is the wall of two cells, each roof also a floor, and each floor also a roof. The first tiers consequently are pentagonal, or five-sided, the roof to which they are attached being straight, whilst all the other tiers below are hexagonal, or six-sided, their top being the two planes that form the bottom of the upper tier. Each cell is thus surrounded by six others. These excavations and scoopings form, of course, only the floors of the cells, and from the edg'es of the floors the walls are built. It has been discovered that each cell is perfect in itself, and has six sides of its own, so that the side of one cell does not form a party-wall, as it were, to the cell next to it, but the wall of its neighbour will be spread upon the outside of its own wall. The cells have been separated in order to prove this curious fact; and as every wall of each cell is varnished over with a thin layer of propolis, there is, of course, a double layer of propolis between the cells, by means of which a very careful hand can sufficiently separate the walls to prove that each wall is double. The double walls, however, being. exceedingly thin, and their external edges covered with one ridge of propolis, it is impossible, from their external appearance, to imagine that there is more than one thickness of wax between the cells. Had it not been for the varnish of propolis, the walls would, of course, soon merge into one by the heat of the bive; but that varnish, although inconceivably thin, is quite sufficient to keep them distinct enough for the eye to ascertain that they are double. The cells lie nearly lorizontal, their mouths being a little elevated, and opening upon the street, or passage, which the bee-architect leaves on each side of every comb. Such is the general construction of the cells.

All animals appear to work in a circular direction, or, at all events, in a segment of a circle. This, probably, is occasioned by the creature using some part of its body as a pivot, and thereby necessarily working circularly. If we look at the labours of other insects besides the hive-bee, we find this to be the case. The leaf-cutter bee shaves off a semicircular piece from the edge of a leaf, and fixes it against the sides of her cylindrical cell. Not to mention the 
cells of the wasp, which are subject to the same laws as those of the hive-bee, we find the plates of wooden fibre which surround and protect the nest, to be invariably of a slight bowl-like form, as if the wasp had fixed itself on its feet as a pivot, and with its jaws spread the fibrous mass into small sheets. The cnconns of various insects, when passing into the pupa state, are all examples of the circular instinct. The same instinct is apparent even in the higher animals. When a bird commences her nest, she arranges a tuft of hay or grass in a fork, seats herself in the centre of it, and spins rapidly round, so as to form a circular depression; after which she works the materials round the edge of this depression. The same thing is seen in the nest of the harvest-mouse. Were not the bees so economical of wax, the whole number of cells would probably be cylindrical; but their care of their wax induces them to scrape away as much as can be spared at the junction of the cells. Now if a cylinder is surrounded by other cylinders of equal diameter, six will exactly reach round it; and if the points of junction of the central cylinder were scooped away, the cylinder would immediately become hexagonal or six-sided. So it is with the first set of cells; but the bees having already a hexagonal model on which to work, do not trouble themselves to build cylinders, and then cut away the angles, but work hexagonal cells at once, only the first set being made on the cylindrical principle.

Whilst this first block is thus being deposited in a straight line across the roof of the hive, and hollowed out into cells as fast as it is deposited, the work also continues downwards towards the floor of the hive, other blocks, or combs, are commenced parallel with it, divided only from it and from each other by the streets just mentioned, which are about half an inch broad. And so the work will proceed until the hive is filled with comb. Looking down upon the lines of combs in a completed hive, they would present the shape shown in Fig. 7, presuming the irregularity in the centre did not exist. And why does that irregularity exist? The answer to this question forms one of the many proofs of the weakness of the theory which attempts to divide by strictly defined impassable barriers the faculties of bees, under the name of instinct, from the reason which 


\section{Fig. :}

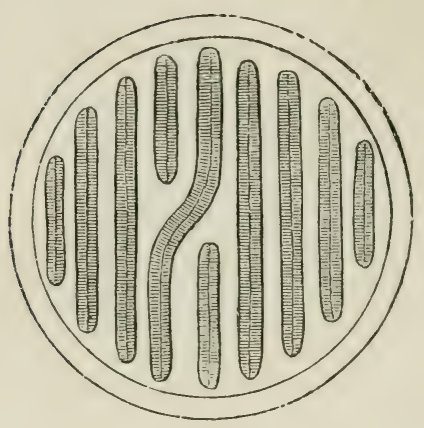

guides ourselves. Between bee-reason and man's reason a space "wide as the poles asunder" may exist; but taking" Dr. Bevan's definition, that reason is the power of making. deductions from previous experience or observation, and thereby adapting means to ends, whilst instinct is the power to perform certain actions in a uniform manner, without reference to either observation or experience, then it is certain that in every department of bee-economy we find numerous examples of the former. The irregularity shown above is a case in point. A stick was in the way of the fourth comb from the left, so the bees deviated to the right into the place of the sixth comb, then resumed their straightforward course. Next, working from the opposite end of the fourth or interrupted comb, they advanced to the interruption and stopped, and so the space there was duly filled up. Then they filled up the unused part of the space that belonged to the fifth comb, which had been so irre gularly intruded upon, by a similar short line, and the general arrang'ement of the hive was scarcely less perfect than ordinary. The reader will observe how carefully the bees have contrived to preserve the proper distance between the combs, in order to permit the free passage of the worker or nurse-bees to their labour in various parts of the hive; sufficient space is always left to enable two bees to pass 
each other as they are pursuing their avocations in the hive. Here again (Fig. 8) is another case of interruption. The

Fig. 8.

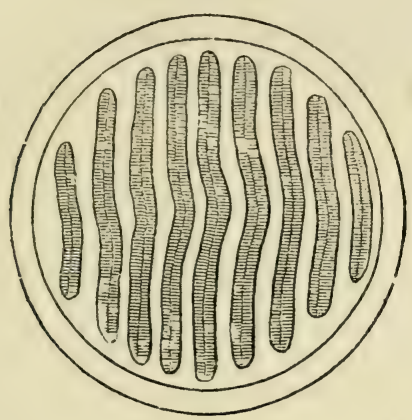

bees apparently found themselves compelled to give such a winding course to the first comb, that they could not do better than exactly imitate its shape for all the others; and how beautiful is the result! Ingenious persons, no doubt, undertake to explain these and a thousand other anomalies in accordance with the theory of instinct; but it is strange that they do not perceive that the effect of their reasoning. is to show that instinct can do all that reason does, and therefore one or the other, as a distinct quality, must be uunecessary. The above cases refer to the first erection of the bees' home. Let us give an illustration of their power of dealing with accidents in the hive. Dr. Bevan tells us, "A very striking illustration of the reasoning" power of bees vccurred to my friend Mr. Walond. Inspecting his beeboxes at the end of October, 1817, he perceived that a centre comb, burdened with honey, had separated firom its attachments, and was leaning against another comb, so as to prevent the passage of the bees between them. This accident excited great activity in the colony, but its nature could not be ascertained at the time." At the end of a week, the weather being cold and the bees clustered to- 
gether, Mr. W. observed through the window of the bos that they had constructed two horizontal pillars betwxt the combs alluded to, and had removed su much of the honey and wax from the top of each as to allow the jassage of a bee: in about ten days more there was an uninterrupted thoroughfare-the detached comb at its upper part had been secured by a strong barrier, and fastened to the window with the spare wax. This being accomplished, the bees removed the horizontal pillars first constructed, as being of no further use.

The power of adapting the construction of their habitation to suit accidental circumstances is not confined to bees alone. A most excellent observer, Mr. Smee, exhibits in his "Instinct and Reason," a very singular instance of this power in a species of wasp. In that work is figured the nest of a wasp, which had been fixed to the branch of a tree. The inhabitants had already completed six tiers of cells (the combs of wasps, it must be remembered, are horizontal instead of vertical), when, from some reason, the branch g'ave way, and threw the entire nest out of the horizontal line In this predicament the wasps abandoned the lines on which the first six tiers were built, and commenced a fresh series of combs, the openings of which opened towards the ground as the former set had done before the accident. The consequence is that the nest being composed of nine tiers of cells, the last three are built at right angles with the first six, forming as curious and instructive an example of the adapting powers of insect instinct as can be imagined.

But the bees wait not for the completion of their grand palace to use it; as soon as a few cells are ready, in come the honey bearers. Each makes his way to a finished chamber, goes as deep into it as he can, opens a hole with his feet in the cream-like crust which the bees have formed for the defence of the honey, and so discharges the honey into the cell through his open mouth. His burden gone, off he flies; others take his place; drop by drop the cell is filled, and then closed so perfectly that the honey will remain good in them for many years. But all the honey thus brought home is not stored. The bringers have been feeding themselves while collecting, but the poor hardworking artisans in the hive have nothing to eat, unless 
they cease their labours and stop the great work of the hive; that they will not do; so the others attend to them with the greatest care and affection. They go to them, they open their mouths (the temporary honey store-house), the hungry, tired workers of the hive put in their proboscides exactly as they would do into a flower, and so eat. It is said, also, that certain robber bees maintain themselves in a gentlemanly and Paul Clifford-like manner, by waylaying industrious common-place bees who have been meritoriously employing themselves in working for the good of their hive, and then compelling the poor innocent creatures to deliver up the contents, not of their saddle but their honeyhag's, generously permitting their victims to set out uninjured in search of more lioney to replace that which they have appropriated to their own uses. The proboscis is too interesting a piece of vital mechanism to be passed by with only an indirect mention. So let us first show it greatly magnified, as in the accompanying engraving' (Fig. 9), and then examine it a little in detail.

(Fig. 9.)

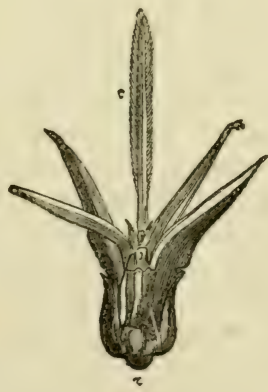

Bees form part of that section of insects called mandibulate insects, $i$. $e$., insects which eat with jaws, in contradistinction to the haustellates, or insects which suck up liquid food through a trunk. Beetles, hornets, and other insects, 
are also mandibulates, but the bees have a further distinc. tion, in that they lap up food with a proboscis, and afterwards transfer that food to their mouth, as the elephant does. This kind of insect is called "lambent," or lapping" insects, from a Latin word "lambere," to lick or lap. It is by means of their mandibles, or jaws, that they are enabled to excavate the wax, smooth the interior of the hive, and perform similar labours; and by means of their proboscides, they moisten, knead, and spread the wax, as well as collect honey. Although the parts of which the proboscis is composed are so minute as to be scarcely visible to the unassisted eye, yet they are quite as complex as those of the mighty elephant's trunk.

The proboscis consists of no less than five distinct branches; namely, a central trunk, or tongue, and four horny scales, tapering to a point, convex outwards, and concave towards the trunk. The two outer ones so sheath the inner, as to appear but one single tube. By a joint in the middle they bend or extend all at once, carrying: with them the unarticulated or unjointed proboscis, which is cylindrical, and about the size of a human hair, and appears through a magnifier to be composed of successive rings. It has probably as many short muscles as the tongue of a fish, which are capable of moving it in all directions, and towards its termination is furnished with hairs, or villi, some of which at the point are very long, and seem to act like capillary tubes. Mr. Wildman assures us that he has seen the trunk growing big'ger and less by turns, swelling. the instant the bee sucked, and this alternate lessening and enlarg'ement propagated from the extremity to the root What a delicate apparatus of invisible muscles must perform this office! The trunk is capable of being contracted and folded up at pleasure, for if it were constantly extended, it would be exposed to injury. When at rest, therefore, it is doubled up by means of its joint, and lies in a very small compass; the first portion being brought within the lip, and the second part folded under the head and neck; protection is given to it by a double sheath, consisting of four strong scales, the two inner scales sheathing the tongue, and the two outer and larger ones encompassing the whole. When at work, the trunk is lengthened beyond 
its sheaths, probes the very bottem of the flowers, through all impediments of foliage or fructification, and drains them of those treasured sweets which without such an apparatus would be completely inaccessible. The proboscis of the bee is not used like that of flies, as it is not tubular like theirs, but serves as a brush or besom to sweep, or as a tong'ue to lap. Having collected the nectar of Howers in small drops, it deposits its collection upon the tongue, which is protruded for the purpose of receiving it, and having received it, withdrawn again.*

The reader must guard against the common fallacy of supposing' the proboscis to be same thing as the tong'ie, The proboscis is a collection of several organs, which are to be found variously modified in every insect; but the tongue is an extremely minute organ, and is so small and insignificant that a careful examination with a lens is required to detect it. The proboscis collects the honey, and deposits it in the mouth, from whence by the action of the tongue it is passed to the honey-bag.

In some cases, the means used by the bees in order to g'et at the honey are singularly ingenious. The humblebee, as is well-known to observers, when engaged upon the blossoms of the bean, which are too narrow to admit its body, and too long for its trunk to reach to the bottom of the flower where the honey is found, bites a hole just over the part where the honey is found, and through the orifice inserts its proboscis, and extracts the hidden sweets. But it is not so well known that the honey-bee resorts to the same stratagem. It has been repeatedly seen biting through the flower of the common fuschia, and extracting the honey precisely in the same manner as the humble-bee. It may be as well to remark in this place, that the sweet liquid when extracted from the flower, is not what we call honey, lut appears to gain its consistency and peculiar odour in the crop of the bee.

Whilst honey is thus being collected for the present nourishment of the workers in the hive, and for future supjly in case of need (observe, the sealed stores are never touched except in periods of real distress among the com-

- Dr. Evans, in Beran's Honey-Bee. 
munity), another important department of the commissariat of the hive is attended to in a no less exemplary manner. There will be young ones in the hive by and by; how are they to be fed? "Why, with bee-bread, to be sure," answers some old nurse-bee of the hive; and so, having, we may suppose, received their instructions, the bees set out to collect pollen as well as honey, from wherever they can find it. If you watch the bees as they return to the hive, you will scarcely see one of them without a little ball or pellet of farina on each of its hinder-leg's, at the part marked $a$ in the accompanying' engraving' (Fig. 10).

\section{Fig. 10.}

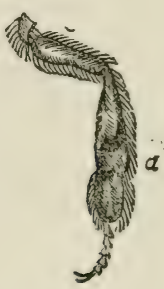

The hinder ler of the Worker-bee; $a$, the part on which the pollen is carried.

Of the six leg's of the bee, the four hinder leg's are used for collecting pollen. On each of them one joint is so thickly covered with thick and highly elastic hairs, that by using these joints as brushes, the bee is enabled to brush the pollen from the stamens. From these leg's the pollen is transferred to the fore pair of leg's, which, by help of the jaws, knead it into a compact mass. This mass is then placed on the hinder legs, where it is defended from falling by a triangular groove edged and covered with thick hairs, which form, together with this groove, a kind of basket, which may be often seen so heavily laden, that it appears almost impossible for the little creature to sustain itself in the air, 
when weighed down with two such comparatively enormous balls of farina.

These balls are invariably of the same colours as the anther-dust of the flower in which these luxurious little rog'ues have been rolling'; there can be no doubt, therefore, that it is of this substance, after it has been used for the reproduction of vegretable life, that the bees take possession, to assist in the rearing of their infantine insect-life : another instance of the economy that exists amidst all the profuse wealth of the natural world. Well, the little pollen-bearers come back to the hives; there they are met by the expectant nurses, who take part of the pollen from them and devour it, but not for themselves, it is only laid by for the future use of the larvæ. It is placed in that singular receptacle the honey bag, where it becomes sufficiently mixed with liquid honey for the young and tender grubs to devour it. It is possible that the bee may be able to regulate the food that passes from the honey-bag into the stomach, as well as that which it regurgitates into the mouth, but it is more probable that, after remaining for a certain time in the honey-bag, it involuntarily passes into the true stomach. As to the rest, watch that bee yonder; after the nurse has done with her she is looking for a cell, making a noise all the while with her wings to call her brethren around her. On reaching the cell, with at least one attendant, she balances herself firmly on the edge with her middle and hind legs, whilst with the fore leg's (her arms and hands) she seizes the farina, drops it into the cell, and leaves the attendant bee to knead it into the bottom and varnish it over, whilst she flies back to "fresh fields and pastures new."

The "bee-bread" is unquestionably composed of the pollen of flowers, probably kneaded up with a little honey, but so little that it is not perceptible to the taste. There have been many discussions as to the exact substances of which this bee-bread is composed. From examinations made by myself, it appears that the bee-bread, when taken at different depths from the same cell, is composed of the pollen taken from different plants, but that which the bee takes home on its thighs, has been invariably found to consist of the pollen of one flower only; so that it would appear that 
each bee, when it starts on its collecting tour, devotes itself to one particular species of blossom. The use of this curious instinct in the fructification of flowers is evident. The bee, by visiting various blossoms, either shakes the pollen from the stamens upon the stigmata, or by bearing. about them the pollen from a male flower, and afterwards visiting a female flower of the same species, renders them fruitful. This great object will, of course, be better secured if the bee only visits one species of flower, as if it visited several, either the pollen might be such as would have no fertilizing effect, or it would produce an endless catalog'ue of varieties which, as is well known, never do occur spontaneously, and are only to be found in the garden of the florist, who often appears to base his happiness on producing a flower as unlike its original form as possible.

There is yet another substance formed by those wonderful little workmen, the bees, namely, propolis, which is of a resinous nature, and derives its name from its uses. This most useful material is obtained principally from the young buds of various plants, which are defended by a resinous varnish from the weather, while they are yet feeble and unable to withstand its inclemency. Among. the principal of the resinous buds we may notice those of the hollyhock, the horse-chestnut, the willow, the poplar, and the fir. It is taken from the bud in threads, moulded upon the thighs, and conveyed home just as the pollen is. The bees seldom make use of it in its original state, but mix it with wax in various proportions according to the work to be executed. It is somewhat singular that bees should employ this substance so extensively, for they are in general violently opposed to the smell of turpentine, and you can hardly insult a bee more than by offering him a little spirits of turpentine to smell. The actions of the poor bee strongly resemble those of a cat which has been forced to inhale the odour of a reasonably powerful bottle of smelling salts.

Propolis signifies before the city; the Greeks having. observed that it was used by the bees to strengthen the outworks of their city. It is with propolis the combs (or the blocks out of which they are constructed) are fastened to the roof of the hive. It is with propolis the bees defend 
themselves from catching cold or rheumatism through draughts, by stopping up every crevice into their hive, no matter how minute, so that one only opening shall exist, the proper legitimate entrance. M. Réaumur once thought proper to fasten the glass of a hive with pasted paper, in a careless manner, before putting in a swarm. Just as he had anticipated, the bees found out his unworkmanlike conduct, and contemptuously tearing away with their teeth the trumpery defence he had put, they made all firm and taut, as the sailors say, with good solid propolis. Once an unlucky shell-less slug crept into a hive. After having settled him with their stings, the bees varnished him carefully over with this same propolis, to prevent his becoming unpleasant in the dog-days. Another, confiding apparently in his impenetrable shell, an impudent, idle, yet honey-loving snail,* thinking to plunder their stores, appeared on the threshold of their dormitory - to learn, alas! most unexpectedly, a new use for this wonderful composition; the bees actually glued him down to the ground, at the edges of his armour, as firm and immoveable as a rock, before he had time even to explain that he was but looking in, and intended to g'o back again instantly.

Propolis has a remarkably rapid drying property. Although when first procured from the tree it is plastic, soft, and can be easily removed in threads like birdlime, yet, in a very. short time after it has been taken from the secreting surface of its native tree, it becomes hard and comparatively brittle. So rapid is this change, that the bees who are engaged in collecting propolis are forced to gather it about noon-day, when the sun is at its height, as the heat of the sun softens it for the time; they are furthermore obliged to work with great rapidity, and hurry homewards directly they have taken a cargo, as, even in the short space of time which their flight homeward consumes, the propolis often becomes so hard, that they can scarcely detach it from their hair-covered baskets.

* While decoying moths at night by means of a fragrant and in. toxicating mixture of beer, sugar, and rum, spread upon the trees, $I$ seldom found one of the trees without one or more large gray slugs already busily devouring the sweet deception, and several more descending from the branches, eager to join in the feast. 
Bees are so fond of this their vegetable mortar, that they will never commence the work of a live until every crevice has been carefully filled up. It is, therefore, a considerable saving of time to the bee-lieeper, to talse care that his hives are closely made, and particularly that they fit quite accurately to the surface of the footboard, as the bees will waste very much of their valuable time in stopping g'aps. Wooden hives, in particular, should be carefully examined, as either the footboard itself, or the bottom of the hive, is apt to shrink, if it has been made of ill-seasoned wood, or has not been clamped. The mansion thus in process of erection, the storehouses thus being rapidly filled, the great mysteries of life and reproduction begin to evolve their wondrous phenomena.

In our respect for the wisdom of some of our ancestors, we cannot but transcribe their theory of the propagation of bees. We have said "theory," but that is hardly the right word; for the following " experiment of the generation of bees," was, it appears, practised by "that great husbandman of Cornwail, old Mr. Carew, of Anthony." Thus run the directions:- "Take a calf, or rather a sturk (steer), of a year old, about the latter end of April, bury it eight or ten days till it begin to putrify and corrupt; then take it forth of the earth, and opening it, lay it under some hedge or wall where it may be most subject to the sun; by the heat whereof it will (a great part of it) turn into maggots, which (without any other care) will live upon the remainder of the corruption. After a while, when they begin to have vings, the whole putrified carcase should be carried to a place prepared where the hives stand ready, to which, being perfumed with honey and sweet herbs, the maggots, after they have received their wings, w:ll resort." This, it appears, was a practical man's method of proceeding to stock his hives. Need we, then, wonder at the ancient poet, whose guidance he was (perhaps imwittingly) following, Virgil, who has given similar directions, only more poetically expressed, in his forrth Georgic:- 
"First in a place, by nature close, they build

A narrow flooring, guttered, wattled, and tiled.

In this four windows are contrived, that strike

To the four winds opposed, their beams oblique.

A steer of two years' old they take, whose head

Now first with burnish'd horns begins to spread ;

They stop his nostrils, while he strives in vain

To breathe free air, and struggles with his pain.

Knocked down he dies; his bowels bruised within

Betray no wound, a thin, unbroken skin.

Extended thus, in their obscene abode

'They leave the beast; but first sweet flowers are strokeci

Beneath his body, broken boughs and thyme,

And pleasing cassia, just renewed in prime.

This must be done, ere spring makes equal day,

When western winds on curling waters play;

Ere painted meads produce the flowery crops,

Or swallows twitter in the chimney-tops.

The tainted blood in this close prison pent

Begins to boil, and through the bones ferment.

Then, wondrous to behold, new creatures rise,

A moving mass at first, and short of thighs ;

Till shooting out with legs, and imped with wings,

The grubs proceed to bees with pointed stings;

And more and more affecting air, they try

Their tender pinions, and begin to fly.

At length, like summer-storms from spreading clouds,

That burst at once, and pour impetuous floods:

Or flights of arrows from the Parthian bows

When from afar they gall embattled foes;

With such a tempest through the skies they steer,

And such a form the winged offspring bear."

DrYDEN's VIRGIL, Georg. IV.1. 417.

Need we wonder that the poet should take on trust in his day, what " that great husbandman of Cornwall" would recommend to others, after trial, in his day, so many centuries later? Let us now see if we cannot trace, with tolerable clearness, nature's own method of proceeding. It is not easy to follow the operations of the bees during the incidents we are about to describe, but patient observers have succeeded in doing so; and with their aid, then, let us again turn our eyes inwards upon the hive. Behold the queen-bee, attended by her guard of some dozen bees, moving slowly and with regal dignity among her subjects. You cannot mistake her for an instant, even if you did not 
see how the way opened for her movements, how all the heads of the workers are inclined towards her as she moves, and how fondly they caress her with their antennæ in passing ; for she is in person every (fraction of an) inch a queen, and bears the stamp of sovereignty upon her in most legible characters. She is larger than any of her subjects, as well as more elegant in her form. The abdomen, especially, is much longer than in the bees around her : the wings much shorter, and the leg's and antennæ of a paler colour.

The queen bee is not so much larger than her subjects as is generally supposed. An old queen certainly is considerably linger, but the difference consists principally in length, as the drone is in reality a larger insect than the queen. I have often had queen-bees which so closely resembled the ordinary working bees, that none but a practised eye could have distinguished them from the ordinary inhabitants of the hive, and several persons to whom they were shown alive could not for some time be persuaded of their regal station. Yet she is easily distinguished from her subjects by many unmistakeable signs. Besides those marks of difference given above, her short wing's cross slightly when she is at rest, thus affording an easy method of separating her from the ordinary bees. This shortness of wing also causes her flight to be very different from that of her subjects-her body hang's down rather more than theirs. Her sting is of a curved form, whereas that of the working bees is straight. 'I'he internal anatomy of the queen-bee may be seen in the engraving, p. 35.

Now that we have been presented to her apiarian majesty as she really is, let us see what opinion older writers held, who were not favoured as we are with all the adjuncts of leaf-hives, mirror hives, and other necessary apparatus for performing the difficult and delicate feat of observing the queen-bee. Even in these days, observers are constantly contradicting each other's researches, and although science has so far advanced in bee-knowledge, yet we are not by any means fully put in possession of the movements of the sovereign of the hive. 'The object of her mysterious aërial excursion, for example, can only be conjectured from analogy, as no telescope lias as yet followed the winged monarch in her flight It is,

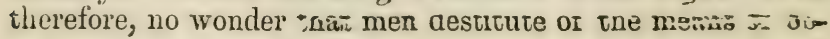


servation which we possess, should have also conjectured from analogy. The great difference between our reasoning. and theirs is, that we, among whom entomology has risen to the rank of a separate science, build our conjectures on the foundation of well known habits of insects, whereas, the older writers, who were unacquainted with entomology, drew their analogies from human governments. The reader will see how completely one author has taken human rule as his guide. After a long description of the personal appearance, and presumed origin of the hive monarch, he proceeds to observe :-

"And if he chance to find among his young" ones any one that is a fool, unhandsome, hairy, of an ang'ry disposition, ill shapen, or naturally ill conditioned, by the unanimous consent of the rest, he gives order to put him to death, lest his soldiery should be disordered, and his subjects being. drawn into faction, should be destroyed. He sets down a way to the rest, gives order what they shall do-some he commands to fetch water, others to make honey-combs within to build them up and garnish them; othersome to go and g'et in provision; those that are stricken in years he cherisheth at home, the younger he exerciseth in labour and vicissitude of employments; and although he himself hath immunity from mechanick labour, yet, as cause shall require, he also refuseth not to work, nor doth he ever go abroad but for health sake or necessity. If he he by reason of ag'e in health, he marches as general in the vanguard of his army, and in person opposeth himself to all encounters; neither is he borne by his attentants willingly, unless it be when he is so old and diseased that he cannot either go or fly. When night comes on, the signal being given by the trumpeter, the common sort are commanded to their lodging, and the watch being set, every one betakes himself to his rest. As long as the king lives, all the swarm enjoys peace, and all things are in quiet, for the drones keep themselves willingly in their own cells, the elder bees are content with their own places, nor do the younger run out of their own into the elders' lodgings. The king lives apart from the rest in a more eminent and large palace, with a waxen fence curiously made, compassed about, as it were, with a kind of wall. $\dot{A}$ little way from him dwell the king's children, to whom, if 
their father or mother do but hold up the finger (as they say), they are husht. But the king being dead, the subjects are perplexed, the drones lay their young' ones in the bees cells, and all thing's are out of order." . . . The author then proceeds to remark how bees are of nine orders, each springing from a different stock. There are lion-bees, bullbees, cow-bees, and calf-bees. The king-bees are those which spring from the brain of the lion, and are endowed with noble qualities according to the kingly brain from which they issued. The noble bees spring from the other parts of the lion, and the canaille from cows, calves, \&c. The author here has made the same mistake as did Shakspeare, who flourished about the same time, in considering' the queen bee as the father of the hive. He is sadly puzzled what to make of the drones, and assigns to them the duties of wet nurses-apparently because he found that they did nothing that he could discover, except faring upon the best of the hive during their sojourn in it. It is another g'reat proof of the genius of Shakspeare, that with such false and absurd accounts as these for his only guide, he has in the description of a hive, which has been betore quoted, instinctively omitted the erroneous accounts, and merely committed the slight error of mistaking the sex of the regal bee. Perhaps it is to be wished that he had known it, as although Dr. Bevan in his preface has chosen a very elegant comparison between the queen-bee and our present queen, yet it is hardly possible that Shakspeare would have omitted such an opportunity for introducing a little delicate flattery towards his sovereign, who has already been so often celebrated in his works.

We will now briefly consider the anatomy of the hive bee, although this little work is wished to be practical, yet as no work can supply every information, or act as a guide under all the various circumstances which must take place in every apiary, it is necessary that the bee-keeper should have some knowledge of bee-anatomy, as without such knowledge, it is impossible to understand the physiology of the insect, and unless the physiology is understood, it is almost impossible that the management can be properly carried on. No man thinks himself fit to undertake the charge of stables, unless he is thoroughly acquainted with the 
characters and the external appearance of horses, and alsn has some knowledge of their complaints or diseases, which presupposes some knowledge of their organs. Yet every one considers that he can keep bees, even if he does not know the differense between the head and the thorax, or considers that the stomach and the honey-bag are identical. We will, therefore, first take a survey of the external organs of the bee.

As all insects are, it is divided into three distinct portions, called the head, the thorax, and the abdomen.

On each side of the head are placed the eyes. They are arranged into two clusters, and appear at first sight to be merely two eyes. Those clusters, however, are, in fact, composed of many thousand each, of a hexagonal form, and closely resembling a honey-comb if placed under a powerful microscope. The surface of the eye is defended from dust, wet, and other annoyances by slightly curved, elastic hairs, springing from the junctions of the angles of the hexagonal eyes. To see the eye properly in the microscope, it must be carefully cleansed from the colouring matter, which will be found lining its interior, and if then it should prove too opaque, Canada balsam will render it sufficiently transparent for the observer. On account of the projecting hemispherical form of these groups of lenses, the insect is enabled to see on every side withou' turning its head, a feat, indeed, which in the bee is impossible, on account of its shape.

The eyes of that most ferocious and ravenous of insects, the tiger-beetle, are remarkably prominent, and the same thing. may be noticed in the swift and rapacious dragon-fly.

Besides these two great groups of composite eyes as they are called, each bee possesses three very small single eyes, called stemmata. These are placed in a triang'ular position upon the very top of the head, and are so minute that they cannot be seen without the aid of a lens of some power. The use of the stemmata has not yet been satisfactorily ascertained.

The antennæ or horns, as they are sometimes called, are organs of considerable importance, but their precise use has never yet been discovered; some think them to be organs of hearing, others that they serve as guides to the bees in their lark hives, and others, perhaps with more reason, that they are the organs of a sense which we ourselves do not posses:3, 
and of which, of course, we are incapable of judging. Whon an insect is deprived of its antennæ, it always appears quite bewildered, and can no longer procure food, guide itself, or even direct its mouth to the food placed before it. Ants, who also belong to the same order as the bees, constantiy touch each other with their antennæ as they pass and repass, and seem to make them their means of communicating ideas -how, is unknown. These organs consist of twelve joints in the female, and of thirteen in the male.

Of the parts of the mouth generally called the proboscis, some description has already been given. This, together with the principal mandibles or jaws is concealed by the upper lip or labrum when the head is examined from above. The palpi appear just outside the labrum. The palpi, which look like very small antennæ, are of considerable importance. Entomologists are more inclined to give them the name of feelers, than to bestow that appellation upon the antennæ, as the insect is always seen to apply them to its food before eating. When deprived of them, the insect does not appear to be thrown into that state of bewilderment, which is caused by the loss of its antennæ. In some insects, such as the great water-beetle (Hyclröus piceus), the palpi are longer and larger than the antennæ.

The thorax is joined to the head by the slight throat. This important portion of the bee's body is principally intended to bear the organs of locomotion. The thorax is divided into three parts, which in beetles where the skeleton is harder than in the bees, can be separated from each other. Of these the first segment, called the prothorax, bears the first pair of leg's, the second segment, called the mesothorax, bears the first pair of wings (which are analogous to the wing-covers of beetles) and the second pair of leg's, while the third segment, called the metathorax, bears the second pair of wing's, and supports the third pair of leg's. The thorax, also, seems to protect the great mass of nervous cords which meet just below the first pair of leg's. The leg. is composed of several joints, and terminated by two hooks, by means of which it is enabled to hang to any substance, as the sloth hang's on a tree, without requiring to use muscular exertion. There is, also, at the sole of the foot, an apnaratus similar to that of the fly, by which it can attaci 
itself to a smooth surfice, by exhausting the air after the manner of a sucker.

The abdomen is the last portion of the body. It is composed externally of rings, diminishing in diameter, and sliding one within another in order to shorten or lengthe: the body. It contains all the most important vital org'ans, which will be described in the paragraph on the internal :natomy of the bee. Along the two sides of the abdomer. are ranged the spiracles, or apertures leading to the respiratory apparatus. The whole of the body is covered more of less thickly with hairs, which when placed under a good microscope prove to be straight and branched, so that a group of hairs looks very like a clump of bamboos.

We will now proceed to the examination of the internal anatomy of the bee. As the anatomy of the humble-bee is precisely the same as that of the hive queen-bee, I have preferred taking it as an example, because its very much superior size enables the various organs to be seen without magnifying, an assistance which should never be had recourse to unless necessary.

On laying open the abdomen of a female humble-bee, the first thing that strikes the observer will be the masses of fat obscuring the organs. As bees are not visited by the ichneumon-flies, like the caterpillars, whose fat is so often kindly cleared away by the iclineumon-larva, the first thing. the dissector must do, is to free the organs from every particle of fat, which by the assistance of a needle and a very fine pair of forceps, he can easiiy do. The following organs will then lie open to him.

Connected with the proboscis, and passing completely through the thorax, will be seen the tube called the cesophagus, or gullet, which serves to convey the food into the next part of the digestive apparatus, the honey-bag. This important organ acts as a reservoir from which the food may either be returned to the mouth, or pass into the true stomach, just below. The honey, when it is taken from the flowers, is stored in the honey-bag until the bee reaches home. In that organ it appears to undergo a change, which gives it the peculiar opacity and consisience so characteristic of good honey. In fact, the honey-bag performs much the same functions in the bee, that the ruminating stornacis 
does in the cow. At the lower part of the honey-oag, the valve is seen which admits the food through a short neck to the true stomach. This is a cylindrical organ increasing in diameter slightly after leaving the honey-bag, and bound by innumerable muscular rings. When the food has reached this point it is beyond the control of the bee, and cannot be regurgitated. In this organ the honey or other food undergoes that change which causes it to be secreted as wax. Lastly, the stomach emerges into the intestine, which after making a few convolutions, passes straight to the extremity of the abdomen.

The organs of reproduction now engage our attention. Passing from the upper part of the abdomen, are seen two slender, slight, thread-like organs, separating near the base of the honey-bag into a number of tubes slightly swelled here and there. These are the ovaries or eggreservoirs, which meet and form a common oviduct, or egg'tube. Opening into the oviduct is a wonderful piece of apparatus called the spermatheca, which retains the vivifying fluid, and appears, as far as we can see, to render each ego fertile, as it passes the opening.

The next object that strikes our attention is the sting. This organ, which has been described in another place, is situated at the extremity of the abdomen. Rather to the left of the sting; the poison-bag is seen, which is supplied with its irritating contents by means of two very fine thread-like glands, which may be seen springing from its summit. The nerves have been removed, as the mass of ganglia, or collections of nervous matter, would have obscured the osophagus entirely. Suffice it to say, that the nervous system of the bee consists of a number of ganglia, of which some very large ones occupy the head, to supply the organs of sight, smell, and touch, while others are placed at intervals down the thorax and abdomen, sending out small nerves to the parts to which they supply feeling. A great collection of ganglia is found in the thorax, and to destroy this part of the nervous system is the most merciful way of killing insects. A smart pinch with the forceps will mostly cause the death of an insect, in the most instantaneoris manner. Insects have no real brain, that is, they seem to bave no nervous centre like the brains of higher animals. 
The respiratory apparatus in insects is composed of iubes. These tubes open down the sides of the abdomen, in valvular apertures, closely fringed with elastic hair, callea spiracles, or breathing-holes. The spiracles communicate with two large tubes that pass along the sides of the abdomen, and from them other tubes spring, traversing every portion of the body, serving as ligatures to keep the internal organs in their proper places, and piercing to the extremities even of the feet and antennæ, so that an insect may be said to breathe with every portion of its body. The cylindrical form of the tubes, together with the necessary flexibility, is preserved in a most wonderful manner. The breathing tubes are composed of several membranes. Between these a fine and very elastic thread is coiled, closely resembling a wire bell-spring. This arrangement preserves the tubes from being flattened, or contracted by any movement; while at the same time, so strong is this thread, that it can easily be removed from the tubes without breaking: I have removed two inches of the spiral thread of the breathing. subes of the humble bee. Even when separated from the tubes, the thread retains its elasticity, and when released? from the forceps, springs into a spiral form again.

\section{(Fig. 11.)}

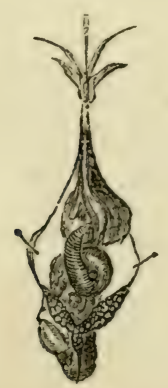

Anatomy of Humbie Rtv,

- From an original dissection. 
The respective appearances of the queen, the worker (or honey-collector, whether known by the name of waxworker, or sculpturer, or nurse-bee), and the drone, of whom we shall speak by and by, are shown in the accompanying shetch. The drnne-bee is even more easily recognised than

Fig. 12.
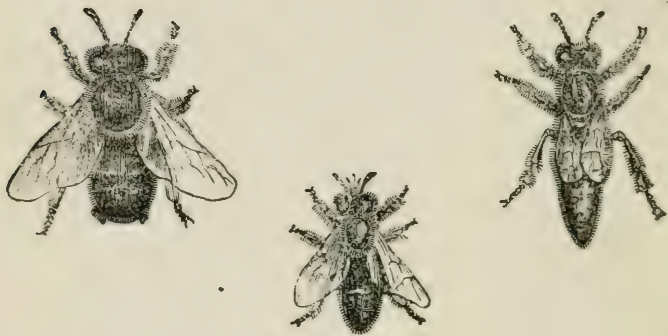

The three descriptions of bees of a hive. The left hand figure is the Drone, the right hand drawing represents the Queen, and tio Worker occupies the centre.

the queen. Its eyes are much larger than those of the ordinary bees, and almost meet at the back of its head. Its body is wide and blunt, its proboscis is short, its head is large and round, and it has no sting. This is the male insect, and each hive contains from 1,500 to 2,000 of them, according to its strength. When flying it makes a deeper lium than the worker-bees.

The working-bees, which compose the great mass of the inhabitants of the hive, are the manufacturers of the wax and honey, and architects of the comb. Each worker is peculiarly fitted for the labour which it performs. On the tibia, or shank of the hind-leg, is a little basket, in which it conveys its burden home. It is also furnished with a receptacle within its body, wherein it, carries home the honey obtained from the Howers, and from which it can at any time reject the contents, a power absolutely neces- 
Eary, as it has to fill the cells with honey which it lias first swallowed. It is also furnished with a pair of very power ful jaws, moving laterally. These jaws are extensively userl in the architecture of the combs, and general economy of the hive. Its sting (which is described more largely in another place) is straight. The most curious circumstance about the worker-bees is, that that they are all undeveloped females, and can, when in their larva state, be metamorphosed into queens. Now and then a workerbee becomes partly fertile; but it never lays any but drone rg.j. This partial fertility is probably occasioned by some of the royal bee-bread dropping into the cells of those worker-bees located near the royal cell. More probability attaches itself to this theory from the circumstance, that these fertile workers never appear except in hives where the bees have lost their queen, and have been obliged to elevate a worker larva to the regal throne.

The question of the sex of the worker-bees was curiousiv enoug'h established by the dissections of a young lady, whose loss is to be deplored by all naturalists, Mdlle. Jurine From some cause or other, most probably from want of equal skill, I have never been able to verify her dissections to my own satisfaction, the small masses, at first supposed. to be undeveloped ovaries, g'enerally turning out, when eramined by the microscope, to be congeries of air-tubes. In the museum of the College of Surgeons are several preparations, which are asserted to show the undeveloped ovaries of the worker-bee.

Look again into the hive. The queen is about to commence her maternal labours in the deposition of eg's, firon. which are to issue the fiuture community, or possibly half-adozen communities. To shut out from prying eyes, and invest the whole affair with the solemnity and splendou: befitting the occasion, a living curtain is formed impene. trable to all but the most patient, skilful, and fortunate eyes. The bees attach themselves to each other in the mode before pointed out; but then the object was to form a ladder, now it is a screen required. So they connect themselves into a dense mass, a perfect " grape-like cluster, or living. grarland." This is done with such wonderful skill and ease, that bees can fly off from the cluster, even from its 
very centre, without exciting confusion in the group. Who strength of the topmost bees is here shown even more strikingly than in the formation of the ladder; the bees at the top liave, in these moveable clusters, nothing to take hold of to enable them to support the weingt of their comrades, and appear to need nothing. Possibly, as Mr. Wildman supposes, they may possess some power of distension, and so, like fishes, buoy themselves up. Although the strength of insects is surprising when contrasted with the comparative strength of the larger animals, I am inclined to think that muscular strength has little to do with the power of the bees to sustain a great weight by their claws. The shape of the claws is such that if a dead bee is talien, and its feet placed in the proper position, it will hold up not only its own weight, but that of several other bees added to it. Of course by its muscular power it can so arrange the claws as to enable it to sustain the greatest amount of weight compatible with the integrity of the claw; but when its feet are once fixed, the bee displays its strength not so much in retaining its hold, but by its power of releasing itself at will. Most people have felt the strug'gle; of a cockchafer to get loose from the entanglements in which it has involved itself by flying heedlessly against unwary passengers in the dusk of the evening, and must have noticed how firmly the claws retained their hold, even though the terrified insect was perfectly willing to loosen them.

Thus attended, and amid all the rejoicing's of her subjects, the queen proceeds to a cell, thrusts her head into it to see if it be quite as it ought to be, which of course it is among such zealous and industrious housewives, then turning; she inserts her abdomen, leaves an eg' in an upright position, fixed by a glutinous matter, and moves on to repeat the operation in another cell. The fecundity of the queen partakes almost of the miraculous. Huber speaks of 200 eg's daily being laid; Schirach, of 100,000 in a seasun; whilst a correspondent of the Gardeners' Chronicle has had. queens that have laid 1,000 a-day for three months in succession.

Almost incredible as this account may appear, the queenwee is far surpassed in fecundity by the queen of tho ter- 
mite, $\mathrm{Or}^{2}$ white-ant, as it is often erroneously called. Thiz creature, who measures in her virgin state about hali-aninch in length, and proportionably wide-not quite so large as a small wasp-when laying, measures three inches in length, and about an inch in diameter. The whole of this enormous mass is composed of eg'g's, which are laid at the rate of sixty per minute.

During a considerable period the eg'g of workers alone are deposited, or in other words, eg'o's are deposited. in the cells for the worker-bees only, which form the great mass of the cells, as the workers form the great bulk of the bee community. But after a certain time the queen begins to lay eggs in the cells of the drones, which are larger and more substantial than the cells of the workers, and later built. Their position is generally near the bottom of the combs, And now, by what mysterious law is it that twenty days after these drone-cells receive their eg's, from which are to spring the males of the future community, the worker-bees begin the erection of a still more stately species of cell for the deposition of the eg's that are to become queens, and to be fertilized by the said drones? Who can tell? These royal cells show how little of mere routine, or slavish adherence to instinct, guides. the bees. They differ in their numbers in different hives, from three or four, to twelve or thirteen; they are situsced frequently at the sides of the combs, but are also found in the very centre, standing erect like a queenly palace, nearly two inches high, and erected with a most loyal disregard of all those habits of economy which the bees show in so striking a manner in their meaner erections. Thus, for instance, they will use as much wax to build one of the royal cradles, as would suffice for a hundred of the others. The form of the royal cell is not unlike that of a pear suspended perpendicularly, with the sides or walls full of holes.

For four days the egrg of the worker-bee remains apparently unchanged. But the vital principle is at work within, and at the appointed time, on the fifth day, a small white worm, with several ventral rings, appears at the bottom of each cell. This increases in size, nourished probably by the whitish transparent fluid in which is 
IIE. I3.

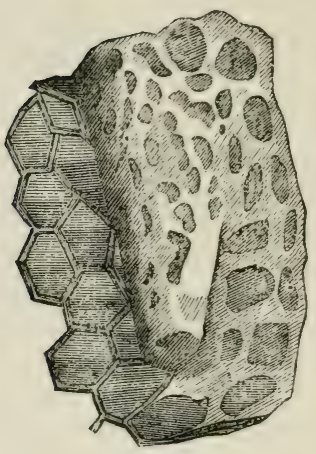

Royal ccll.

floats, until its extremities touch the sides of ti:c cell, when they curve, and begin to approach each other, until they almost form a ring. The nurse-bees now come to feed it with bee-bread; the little worm, larra, maggot, or grub (for by all these names it is known), opens its lateral pincers, and the precious morsels are eagerly devoured. Réaumur supposes that this bee-bread is no longer what it at first was, farina merely, but that it is mixed in the stomach of the nursing-bees with honey and water. He even thinks the nurse-bees can alter the relative strength, as it were, of this mixture, to suit the strong or more delicate stomachs of the nursling's, as they are more or less advanced in growth. We shall see, by and by, that they can not only do this, but have important objects to attain in so doing'. The larve soon show the effects of such good feeding, by nearly filling up the whole space of their cells. That is the signal for a new opeiation. The nursing-bees now seal up the cells with a ligit-brown cover. No more luxurious feeding' at present. "The larva 
must begin to work. It is the lot of all, bees as well as men. Happily for the bees, they seem never to have any doubt, or to make any fuss, about their " mission," strange, and wonderful, and beantiful as are the operations they have to perform. To live, to know their work, and to do it, ere with them convertible propositions. The larva now begins to line the cell with a silky film, alternately shortening and lengthening its body in the process. This silky thread proceeds from the middle part of the under lip, and is composed of two threads gummed together as they issue firom the two adjoining orifices of the spinner. The larva then encloses itself in a cocoon, after the fashion of the silkworm, and looks not very unlike an Egyptian mummy in its swaddling-clothes. This process completed, in anout thirtysix hours, it is no longer a larva, but a pupa or nymph. At last comes the hour of true birth, when the young imago, as it is now called, shall breathe the pure air of the external world, and bask in the rays of the golden sunshine. On the twenty-first day after the deposition of the eggrs, the young ones, of a grayish colour, may occasionally be seen in front of the hive, undergoing the process of purification at the hands of the nurse-bees.

After the pupa-bee has passed through its various changes, its first movement towards entering its new state of existence, is to gnaw through the cover of the cell. This it does without much difficulty; but releasing itself from the cell is quite another matter, for the other bees do not give it the slightest assistance towards freeing itself from its embarrassments. An accurate observer has repeatedly scen an unfortunate bee, after many struggles, enabled to pole its head out of the cell, and look round upon the new world presented to its gaze, when just as it was on the point of forcing its shoulders out, a body of unfeeling. worker-bees ran over it in the pursuit of their daily avocations, and compelled the unfortunate insect to dive back into the cell from which it had so recently emerged. Again and again had the poor bee to retreat just as it had efiected its escape, and not until after numerous interrupi:ons of the same nature, were its persevering endeavours conned with success. The nurse-bees pay the most unvemintiang attention to the young bees, fom the time that 
the ego is hatched until the cell is closed; vut then they appear to think no more about the matter, and leave the infant bee to its fate with the most philosophical indiffirence. This only relates to worker-bees, for the nursebees have repeatedly been seen to assist the drones, and their assiduity in attending on the young queens is quite as great at the time of their emerging as when they were first hatched. Some days elapse before the young worker-bees and drones can fly. As to the queen, special provision is made, as we shall see presently.

The internal changes of the bee during this period are no less remarkable than the external changes, and are exceedingly interesting to the dissector. The tube, enormously large in the middle, and very small at each end, which at first formed the entire digestive system, g'radually contracts in diameter; the part immediately behind the thorax begins to swell at one side, and is gradually changed into the honey-bag; the intestine first makes a small bend out of its straight course, then makes one twist, and then another, until the whole beautiful machinery is completed. In the Museum of Anatomy, at Oxford, is a complete series of dissections to illustrate the changes of the dig'estive organs. If any of my readers should wish to dissect bees for themselves, I would recommend them to begin with the humblebee, as its much greater size renders it easier to the unpractised dissector, and its internal anatomy is almost precisely the same as that of the queen hive-bee. Queen-bees are too scarce to waste; but female humble-bees may be obtained any day. I do not know a more beautiful sight than a series of well-executed dissections of the humblebee. By taking a nest they may be found in all stages, and a few weeks spent in careful examination and dissection (always taking care to sketch, if possible, any circumstance that seems remarkable) will give more real knowledge on the subject than reading' a host of books. Few tools are requisite. A pair of Beale's dissecting' scissor's, a pair of fine forceps, a magnifying-glass, and a few needles, are all the requisites. The insect should be finstened to a plate of cork loaded with lead, and sunk under water or spirit, from which it must never be removed, or the delicate organ;, deprived of their original attachments, and burdened with 
the weight of water hanging upon them, will burst, ard render all the labour of the operator useless.

The people thus rapidly coming into existence, where are its future governors? Watch the old queen as the spring. advances, the period when all these changes are at their climax, and you will be more than ever astonished at the wondrous phenomena of the bee-mind. See how restlessly she runs about. Now she seems about to go on laying eg'g's; but hurriedly withdraws without doing so. No wonder she is agitated. She is about to abdicate; not about to lay down the cares and glory of sovereignty, certainly; but about to quit her established, peaceable, and quiet kingdom, to go she knows not whither, with a part of her subjects, exposed to she knows not what accidents before she may again find herself by her comfortable, regal, warm comb (her fire) side. But she respects the laws of nature, and obeys them. In those cells which she runs; over in so much agitation, lurks her successor, waiting but for the proper hour to ascend the throne. How easily she could tear open the cells and destroy her! But a power greater than ambition withholds her. The bees no longer pay her their usual attention. An idea of divided alle. giance seems troubling them. They get as excited as their queen. Some terrible calamity-civil war, perhaps-impends. Oh, no! the bees are at once too sensible and too unselfish. They divide-perhaps take leave of each other affectionately-and off goes the first swarm, led by their reluctant but duty-obeying monarch.

The swarm does not go off at an early period of the day, or at a very late one, but generally starts from its parent hive between ten in the morning to three or four in the afternoon, although instances have been known of swarnzs starting as early as seven in the morning, and as late as five in the afternoon. This instinct is useful enough to the proprietor who is anxiously expecting a swarm, as he need not commence his watch before seven or eight, and is relensed about four. It seems rather strange that the rightful queen should always go off with the swarm instead of remaining in office and sending the newly emancipated princess, if she may be so called, to take charge of the swarm. But so it is, ard almost every queen-bee owes her throne to usurpation, 
and will in all probability, if she lives long enough, be dis. possessed of it by the same means. She makes a terrible disturbance though, before she does set off; and were the hees possessed of reason, we might almost think that ther left the hive for the sake of peace and quietness. At all events the old queen uses her experience to some purpose, for she will not leave her former kingrlom unless the day is a very fine one. The succeeding swarms appear to pay less attention to the weather. The period of delightful coolness which succeeds a summer storm is a common time for the swarm to rise on the wing. If the bee-keeper thinks that the swarm is starting too soon, he can generally send it back into the hive, by g'ently sprinkling the cluster of bees as they hang out of the hive, with water from a small watering-pot. The same means have been adopted to make the swallm alight where it was wanted, but as water cannot always be thrown high enough to reach a swarm on the wing, sand has been found sufficient for the purpose, and the bees, mistaking it for rain, come down at once and settle in some sheltered place. Some bee-keepers recommend firing a gun, which the bees may possibly mistahe for thunder. It is a mistake to suppose that a number of swarms will make the hives richer, as a weak hive will necessarily be a poor one, and in many cases the latter swarms are merely caused by the violent conduct of the young queens, who make such a disturbance in the hive that the bees attach themselves to one of them and leave the hive to avoid these disturbances. Sometimes two or even more queens go with a swarm, in which case there is a battle royal when they arrive at their new residence. Sometimes, also, two swarms select the same spot for their resting place, when a fight is inevitable, hut it is a general fight, and not confined to the queens only.

When the swarm has settled, an empty hive should be placed under them, and the bough on which the bees are clustering sharply struck, when they will fall into the hive, which should be immediately placed on a cloth spread on the ground, and the bees will soon ascend into the hive, which should be previously sprinkled with sugar and ale, or smeared with honey on the inside.

If the swarm is too small to make a strong. hive it will be 
botter to send it back again to its parent hive. This can be done by searching. for, and removing the queen, when the bees will generally return upon discovering their loss, or can at all events be taken to the door of the hive, when they will re-enter of their own accord. The proper weight of a swarm is from five to seven pounds, and all swarms under that weight should be united to others. If the weather is unfavourable after a new swarm is hived, it will be necessary to feed the bees until a chang'e of weather enables them to seek food for themselves, as they have no food in store. Some bee-master's recommend that a newly hived swarm should always be fed for a few days.

But bees colonize-not merely emigrate. It is not merely the young surplus population that are compelled to go forth, but, on the contrary, a mixture of bees of all ages, and, no doubt, of all conditions. They do not rush away from home careless of what becomes of them when abroad. They do not trust to bee-gossip of the advantages of this place, or the disadvantag'es of that; and find out too late how absurd they have been. No, they send out scouts to examine the face of the country, and make them proper reports. Would one could look at a few of the bee "blue-books." As this fict of the scouts has been doubted by some of the bee-men, who seem to think the only way to understand these insects, is to think as meanly as possible of their capacity, we may observe that the following cases are given by Dr. Bevan, on thr authority of one of the most accurate and profound of observers, Mr. Knight, from a paper published in the Philosophical Transactions, in the form of a letter to Sir Joseph Banks. "On one occasion he observed from twenty to thirty bees paying daily visits to some decayed trees, about a mile distant from his garden; the bees appeared to be busily employed in examining the hollow parts, and particularly the dead knots around them, as if apprehensive of the knots admitting moisture. In about fourteen days these seeming surveyors were followed by a large swarm from his apiary, which was watched the whole way, till it.alighted in one of these cavities. It was observed to journey nearly in a direct line from the apiary to the tree. On several similar occasions the bees selected that cavity which Mr. Knight thought best adapted to their use." He noticed at another 
time that a tree, after having been examined and apperertity approved, was deserted in favour of a hive; a circumstance he attributes to long hereditary habits of domestication. That they do prefer such homes appears tolerably clear, for they will flock to them under unpromising circumstances, such, for instance, as the hive in question being strewed over with dead bees. But probably the bees know periectly well how to estimate the value of such an alarming-looking' spectacle; and can accurately determine whether it was owing to any peculiar defects in the hive, or simply to some one or other of those jlls to which bees are heir. Mr. Grant, the author of some very interesting papers on bees in the Gardener's Chronicle, witnessed their operations in a case of this kind. "In a quarter of an hour from their taking" possession, they were observed busily employing bringing out the dead bees, small fragments of honey-comb, dead insects, and other dirt; and by the middle of the following. day a little conical heap of their cleansing's was to be seen on the ground in front of the hive; before night well loaded labourers were seen entering to repair the dilapidations, and refurnish the empty cells."

In the delicate and rather hazardous operation of securing. a swarm, it will add considerably to the ease and carefulness of the operator if he is well defended from the bees. There are some persons who may do anything with bees, such as the celebrated Wildman, who was accustomed to amuse himself by making a swarm of bees settle on his chin like a beard, or hang from his hand, together with many other feats of the like nature, but there are many whom the bees detest, and who on that account cannot venture to meddle with a hive. Even the illness of a formerly loved master has been known to destroy the allegiance of his bees, who would not suffer him to liandle them until he had perfectly recovered. A bee-dress is therefore requisite. This consists principally of a large piece of gauze or net, tied round a widebrimmed hat, and fastened securely round the shoulders. The hands should be defended with woollen gloves, whose thickness prevents the sting from reaching the skin, while the bee can easily withdraw its weapon after the attack. The gloves should be drawn over the buttoned cuffs of the roat. Thus defended the bee-owner may laugh at the 
attacks of a thousand bees. The hands and face may an a further precaution be rubbed with sweet herbs. It is necrs:sary that the brim of the hat be very wide, as otherwise the veil sits closely upon the tip of the nose and the point of the chin, neither of which, particularly the former, are agreeasle places to be disfigured with the sting of a bee. If at any time a bee succeeds in fixing its sting, there is no better cure than a little ammonia or hartshorn rubbed on the place. No bee-keeper should be without a small bottle of hartsLorn, which must be always kept carefully stopped.

The swarm once resettled in their new habitation, their labours begin with the construction of the comb in the mode we have already described in the preceding: pages.

But the round of the yearly phenomena in the old hive is not yet completed. We must see what passes in the hive after the departure of the first swarm or colony, which generally takes place in the morning, or middle of the day, when a great number of the bees are abroad, collecting honey; Stirring news for them to receive as they return to the live ! However, there is no time for lamentation; no good in disorder. So, gradually, quiet is restored. And then we may see the nurse-bees once more at work, engaged not only in tending the ordinary young, but in what may be called the culminating point of their annual labours, the helping forth into the world the royal scions, and from which they will supply their own queenless realm. They accordingly scrape away from one of the royal cells the wax that has been so lavishly bestowed upon it. Doubt not but they know which is the right one, that is to say, where lies the oldest of the young unborn queens. And here is exhibited another remarkable example of the bee-provision. The egg's in the royal cells were all laid with an interval of at least a day between each. Now that they are coming to maturity accordingly, they come not altogether, but in due succession, by which means the bees, as we shall see, have time to know how many of them they shall want, and be able to provide? accordingiy. In due time the royal pupa within obeys the stirring influences that call upon her to burst her cerement, and she would at once emerge into perfect life, but that the nurse-bees, who keep watch and ward over her, knowing. what is good for her better than she does herself as yec, 
smmediately solder over the top of the cell with war, and keep her prisoner for about two days. Why? In order, evidently, that she may not, like the young bees, be unable to fly when she emerges from the hive. And this is not left to g"uess-work. The bees know accurately when she is jrepared, and most likely, by means of the quality or nature of the sounds she emits, which to man's grosser ears come in the shape of a number of monotonous notes, so rapidly repeated as almost to combine into one continuons sound. At last she comes forth in her perfect beauty and power. What an hour is that for the bees; especially for those inlefatigable, careful, admirable, model matrons and housewives, the nurse-bees! We envy Mr. Grant the pleasure he once enjoyed of "having" an excellent view of the young queen, about two inches above the entrance, enjoying and cleaning herself, and receiving great attentions from her subjects." But it is in every sense a spring season, with its chang'eable weathers and moods. The young queen learns -how, we wish some one would tell us-that there are other young queens, successors and possible rivals, in the hive. She, too, grows excited, whilst, unlike the old gueen, she knows not what to do between conflicting impulses. She rushes to the cells-she will tear them open-she will sting the tenants to death-she will-but no; the cells are powerfully guarded, it is for the community to determine in a legitimate mode how these vast questions are to be dealt with; they warn her away; they bite her if she resists. She would even be in danger, but that, in case of extremity, she is in possession of some magical words (we tell no fairytale) that in an instant render the sentinels motionless. But if, taking advantag'e of this calm, she again approaches the forbidden ground, they recover themselves, and, in military phrase, do their duty. Huber witnessed this most interesting scene more than once. He describes the young queen at such a time as standing with her thorax agrainst a comb, and crossing her wings upon her back, keeping them in motion, but not unfolding them, whilst she emitted the dread mysterious sounds, which were responded to by the weaker and hoarser cries of the yet pent-up unborn queens that she seeks to destroy. And what is it the bees want her to do, but learn the lesson bequeathed to her by her predecessor- 
leave the hive with another colony, and relinquish the rights of sovereignty over the parent community in favour of one of her helpless sisters. And so, at last, she departs, and a second colony is speedily in course of establishment. Possibly a third, and yet a fourth, and a fifth, may follow; the number of swarms being determined, no doubt, in ordinary circumstances, by the number of the bees, and the heat of the hive. But when the last swarm has departed, and the number of the inhabitants so lessened that the guards of the royal cells can no longer preserve their efficiency, the remaining young queens emerge as they please, two or three at a time, and civil war, alas! does at last take place. But what an admirable mode of making civil war it is. It is the monarchs who fight, and who are but few in number, and must, therefore, soon bring the contest to an end; it is the bee-people that look on, quite content to pay allegiance to the conqueror. Of course no bee-subject can thus be in danger, by espousing the wrong' side, of losing his property, or his rank, or have his temper exasperated by defeat and humiliation; the contest affects none of these things. Let us, too, watch the contest. Two young' aspirants for the throne are meeting; they rush at each other; each seizes with her teeth the antennæ of her rival; they cling in mortal combat so close together that head, belly, and breast are mutually opposed. But nature has made them aware of their value, or possible value, supposing there were no other incipient sovereigns in the hive; and of the danger of instant death to both, should they in that position launch at each other the fatal dart. So they separate by a tacit mutual consent, and would apparently leave the combat to be determined at some other time. But that will not do for the bees. They can stand no shilly-shallying in the matter. They must and will know who is to be their ruler. Is government to stand still because the would-be governors are cowards? Certainly not. So the rivals are again driven together into the area, no matter how often the queens seek to evade the mortal issue, until at last the stronger one seizes the other by the wing, curls her extremities under the body, and intlicts the death-pang.

'The constitution of the queen-bee appear's to be much stronger than that of the ordinary bees. When a drone beo 
is pierced with a sting, he dies almost immeaiately, but the queen, although she is completely disabled, does not actually die for several hours, but remains crawling about the hive in a state of utter debility, while the victorious queen, knowing that her late opponent is incapable of doing any mischief, quietly lets her crawl about as much as she likes, and disdains to attack her a second time. She is now unquestioned mistress of the live. Love succeeds to war. The Amazon of the hour changes for an equally brief period, to the tender virgin, whom many aspire to woo and win. High in the air, where no eyes may follow, the drones pre. pare her nuptial couch. Before she ascends, she looks carefully around her, perhaps to assure herself ag'ainst prying eyes, perhaps to know her own king'dom again, of which she has yet had so little experience. A few coy half-flights now take place, as though her mind misgave her, and, ât last, she rises, describing in her flight large horizontal circles, until she is beyond the ken of human eyes. She returns in about half an hour, and so ends her brief time of love. Henceforward she is the queen and the mother (literally) of her people, and exhibits accordingly, ever afterwards, the gravity and decorum suitable to her exalted position.

Although the queen-bee is really the mother of the hive, this privilege of hers is now and then usurped by a subject. It does sometimes happen that the worker-bees become fertile and lay egg's as well as the queen. This curious fact serves to prove the assertion that worker-bees are but undeveloped females. The fertile worker, however, deposits only eg's which become drones. The fact of their fertility is accounted for by supposing that some of the food intended for the royal nursling, and which is more pungent and stimulating than the food of the ordinary bees, has by the clumsiness of the nurse-bees been dropped into their cells while they were in their larva state. This conjecture is rendered more probable by the fact that those fertile worker's invariably issue from cells near those fortunate bees who have been transformed into queen-bees by the ordinary process. When it so happens that the lawful sovereign of the hive has not been impregnated within twenty days after her emerging from her cell, the eg'g's which she lays will produce nothing but drones. The ego's producing drones 
are in all cases laid late, but it cioes appear a very singular fact that a delay of so short a period should metamorphose the whole of the contents of the ovaries into male egg's. Huber conceived that the drones appeared thus late on account of the young queens.

A sad business iemains behind. The post of queen's. favourite has always been an honour of dubious value, often of tragic ending, even among mankind; with bees it is inevitably a fatal destiny. No sooner is the business of swarming ended, and the worker-bees satisfied there will be no lack of fertile queens, than issues the terrible edict for the massacre of the drones. Poor fellows! It is to be hoped they comfort themselves with the reflection that their fate is an everlasting homily, presented by nature in dogmatical but most effective fashion, of the uselessness of all who labour not for their living. If one must die for the good of one's kind, by all means let it be as a martyr. Yoor fellows! how they dart in and out, and up and down the hive, in the vain hope of escape. The workers are inexorable. Huber tells us the latter plant their stings so deeply-for the most part between the segments of the abdomen-that they cannot extricate themselves without turning as upon a pivot. The cruelty apparent in the fierceness of the attack is perhaps only kindness, for the wound is immediately fatal: the drones expand their wings, and die. All the drones, however, are not stung to death. Some are merely disabled by the workers, who bite and injure the roots of their wing's so as to prevent them from taking to flight, while others appear to be merely expelled from the community and escape unhurt, although they are too wise to attempt to return; at all events, whether stung, maimed, or expelled, they all perish, and probably the fate of those who perish within the hive is to be preferred to that of the unfortunate bees who suffer a ling'ering' death from cold or hung'er, as they can find no warm hive to shelter them, and do not know how to seek honey from flowers, as they have always fed from the stores at home. The unfortunate drones do not resign themselves: to their fate as meekly as might be expected, but offer a most vigorous resistance to their murderers. Their struggles. are of course vain, for they are overpowered by numbers $s_{g}$ and their jaws and wings, however powerful, can but poorly 
resist the active little working-bee who is, in addition to these weapons, armed with its formidable sting.

The instrument of all this slaughter, the sting, is certainly one of the most beantiful and perfect weapons in creation. Look at the edge of a razor, or a needle's point, and a bee's sting, under the microscope, and then perhaps some idea of its exquisite character may dawn upon the mind. Whilst the razor-edge looks like the back of a stout knife, villainously made, too blunt and uneven to cleave a billet of wood; whilst the point of the needle appears to be some quarter of an inch broad, and of irregular shape, full of holes and scratches, the sting shows everywhere the most consummate workmanship, ending in a point that even when so highly magnified, still appears fine and sharp. Yet this penetrates instantly the comparatively thick skin of a man's hand. And this again is but the scabbard or sheath of still more delicate instruments, namely, two bearded darts. With regard to this curious instrument, the sting, it may be as well to mention that no insects except the Hymenoptera possess it, and of those only the females are thus armed, the males in all cases being harmless. Moreover, comparatively few of the $\mathrm{Hy}_{\mathrm{y}}$ menoptera possess a true sting, by which is meant, a sting that can penetrate, and instil poison into the wound. Many hymenopterous insects, such as the ichneumon flies, have the sting enormously developed, in some reaching more than an inch in ?ength, but these are unable to penetrate even the most delicate skin with their apparently formidable weapon, which is only used for depositing their eg's in a proper locality. The sting acts thus:-When the bee is about to sting, the sheath is first thrust in to make an opening; then follows one of the darts, penetrating a little farther into the flesh, and holding by the four beards on its outer side; then the other makes a still farther advance, and so they progress altsrnately until they acquire a firm hold of the offending" brody. Lastly, there issues into the wounds thus made, it poison from the reservoir at the base of the sheath. The poison which renders the trifling wound caused by the sting to be so painful, is secreted in two thread-shaped glands lying along the intestine. These glands pour the poison into a small bag-shaped receptacle at the base of the sting,"witk: which it is connected by a short duct, and by means of which 
duct the poison is conducted into the canal of the sting. As Paley has justly observed, "the machinery would have been ineffective without the rankling poison; the poison could not have been used unless some opening. were made for it: a striking, example, indeed, of the union of chemistry and mechanism." The pain of the bee's sting may be considerably lessened by a few very simple precautions. If the pigmy but formidable assailant be permitted quietly to withdraw its sting, the smart will be much relieved. and will wholly disappear if a little hartshorn be applied to the wound. If, however, the bee has inserted its sting and left it behind, in a part that can be moved about, as in the hand, if it is so held that the poison-bag of the sting hangs downwards, very little poison will enter the wound. I was once attacked by a bee which settled on my thumb, a'sd then Hew off, leaving its sting inserted in the skin. I was not aware that the bee had used its sting at all, until convinced by actual inspection. The base of the sting was then hanging downwards and caused no pain, but when in the course of inspection the point of the sting became lower than its base, the smart very soon showed that the poison had begun to pour into the wound. Upon again inverting it, and immediately taking out the sting, very little inconvenience was felt. After extracting a sting it is useful to press the barrel of a key firmly round the part. This precaution will prevent the poison from spreading, and also bring it more surely in contact with the hartshorn which has been placed upon it, or will guard it until the hartshorn can be applied. In the absence of hartshorn, any alkaline substance will alleviate the smart, as the poison is of an acid nature, and is neutraIized by the alkali. Common soda will answer tolerably well, but hartshorn is the best remedy, and a supply should always be carried about the person in a small bottle, when any operations against bees, wasps, or hornets, are in progress, as even the armour of a bee-dress does sometimes suffer damages which permit the entrance of an infuriated bee, who will be certain to employ its sting in a most uncomfortable manner. Soap has been tried with some success, and the leaf of the common dock, which is so useful as a renredy angainst the stings of the vegretable wasp, the nettle, is no ineffectual remedy. 
The ordinary tenor of the bees' unwritten constitution regarding the succession to the throne having been thus indicated, there remains to ask what do they do in case of accident, supposing their queen to be lost or dead, and no other young queens forthcoming from the royal cells? This is perhaps, even among so many interesting phenomena as bees afford, the most interesting of all. And first, let us ask how they know when a queen is lost? Of course if she is lying dead before them, they can at once perceive the extent of their calamity, and very touching is the mournful respect they pay to her deceased body. But how is it that in a hive, say of twenty thousand bees, the whole are in a state of profound agitation very soon after her abstraction? It has been said, that if they do not touch her with their antennæe occasionally they at once conclude she is lost. But surely it is not meant to say that twenty thousand bees can be for ever touching the queen in endless and due rotation in order to be satisfied of her presence? Clearly the bees have a langruage. Look at the many incidents already narrated, for whicl. some kind of language appears indispensable, and without which we cannot imagine their truth. Indeed, there is not one of them in which the supposition of a power of aapid communication from one to many does not seem involved. Huber's experiment showed, we think, that the bees have a lang'uage, and that the antennæ form the organ. He divided the bees of a hive into two portions-so that no physical communication could take place. The bees, where the queen was not, soon grew agitated, and after waiting a due time, three or four hours usually, evidently said to themselves, "Our queen is lost; let us make another," and set to work accordingly. How, we shall show presently. Huber then repeated the experiment, but opened a communication through a grating wide enough for the antemnæ to pass through. All remained perfectly quiet. Every bee's loyal heart remained placid and content. Now, how conld this happen except in one or other of these three modes? The queen must have come to the grating, and remained there while every one of the bees in the sundered portion came and touched her with his antennæ; or the bees knew positively from each other there was nothing the matter; or lastly, and this is the most rational supposition, they took it for 
granted, as we do, when we hear nothing about our gracious sovereign, that all went well. But if, on the contrary, the bees hear the terrible news that their queen is missing, that no one knows where she is, or when she will return-whar do the poor distracted creatures do? Shakspeare says-

" The Commons, like an angry hive of bees

That want their leader, scatter up and dowr,

And care not whom they sting."

Bees' loyalty is no lip loyalty. Dearly do they love her, snd, so far as they can, protect her. Dr. Warder tested tiris, somewhat cruelly but most decisively. "Having. sliaken on the grass all the bees from a hive which they had only tenanted the day before, he searched for the queen by stirring amongst them with a stick. Having found and placed her, with a few attendants, in a box, she was taken into his parlour, where the box being opened, she and her attendants immediately flew to the window, when he clipped off one of her wing's, returned her to the box, and contined her there for above an hour. In less than a quarter of an hour the swarm ascertained the loss of their queen, and, instead of clustering togrether in one social mass, they diffused themselves over a space of several feet, were much agitated, and uttered a piteous sound. An hour afterwards, they all took flight, and settled upon the hedge where they had first alighted after leaving the parent stock; but instead of hanging tog'ether like a bunch of grapes, as when the queen was with them, and as swarms usu.ily hang, they extended themselves thirty feet along' the hedge, in small bunches of forty, fifty, or more. The queen was now presented to them, when they all quietly gathered round her, with a joyful hum, and formed one harmonious cluster. At night the doctor hived them again, and on the following morning repeated his experiment, to see whether the bees would rise. The queen being in a mutilated state, and unable to accompany them, they surrounded her for several hours, apparently willing to die, with her rather than desert her in distress. The queen was a second time removed, when they spread themselves out again, as though searching for her. Her' repeated restoration to them, at different parts of their circle, produced one uniform result; and these 1roor, logal, 
and luving creatures always marched and countermarched every way as the queen was laid! The doctor persevered in these experiments, till, after five days and nights of fasting, they all died of famine, except the queen, who lived a few hour's long'er, and then died. The attachment of the queen to the working-bees appeared to be equally as strong as their attachment to her; though offered honey on several occasions during the period of hes separation from them, she constantly refused it, disdaining a life that was no life to her without the company of those which she could not have!" What did Burke mean by saying the age of chivalry was gone? Had he forgotten the bees?

If a new or strange queen be introduced into the hive within two or three hours after they have thus lost the rightful snvereign, she will experience an opposite kind of manifestation of bee-loyalty. However true a queen by nature she may be, she is here a pretender. The bees therefore surround her, and starve her to death: they have too much respect for queens to sting them. So do they check undue monarchical encroachments. On the other' hand, if a stranger queen be introduced to them some eighteen hours or so after the loss of their own, they look upon her very differently. She is a benefactor, and welcomed accordingly. It is true, they are guarded in their first reception; they treat her as a prisoner for a time, perhaps still hoping their own beloved mistress may yet return, but in the end she receives the allegiance of all. "If twenty-four hours have passed since the loss of the ordinary queen, the bees are so delighted at the thought of a successor to the vacant throne, that a stranger queen is gladly accepted the instant she presents herself.

But supposing no such fortunate accident to counterbalance the unfortunate one, the bees then resort to the wonderful power that has been given to them of, in a sense, making their own queens. Certain larvæ, two or three dars old, lying in the ordinary cells, and that would in the ordinary course tecome working-bees, are selected; three of the cells adjoining to each of them are broken down and formed into one; the nurses bring the royal bee-brend, or "royal jelly," which is of a more stimulating" pungent character than the ordinary composition, and give the larva 
thus royally destined a lavish supply. They then pass through the usual stage of pupa to that of perfect queen. 'The discoverer, or rather, perhaps, the reviver and promulgator, of this startling metanorphosis was Schirach, a clergyman of Little Bautzen; and his experiments have been confirmed by Huber.

The final experiment which proved this most wonderful and astounding fact, is thus related by himself :- "I put some pieces of comb containing worker's egg's in the cells, of the same kind as those already hatched, into a hive deprived of the queen. The same day several cells were enlarged by the bees, and converted into royal cells, and the worms supplied with a thick bed of jelly. Five were then removed from these cells, and five common worms, which forty-eight hours before we had seen come from the eg'g, substituted for them. The bees did not seem aware of the change; they watched over the new worms the same as those chosen by themselves; they continued enlarging the cells, and closed them at the usual time. When they had hatched them seven days, we removed the cells to see the queens that were to be produced. Two were excluded almost at the same moment, of the largest size, and well formed in every respect. 'The time of the other cells having' elapsed, and no queen appearing, we opened them. In one was a dead queen, but still a nymph, the other two were empty. The worms had spun their silk cocoons, but died before passing into their nymphine state, and presented only a dry skin. I can conceive nothing more conclusive than this experiment. It demonstrates that bees have the power of converting the worms of workers into queens, since they succeeded in procuring queens by operating on the worms which we ourselves had selected."

These facts seem wonderful enough, but Mr. Pettigrew, a well known practical apiarist, will not allow this strange power to be explained by the assertion that the metamorphosis is accomplished by permitting the female grub to attain to its full development, but makes it even more extraordinary by denying that it is merely the egg's of workers that can be thus metamorphosed. He says, "How startling suever it may seem, how donbtful soever my firiends may be, I, were I worth a thousand pounds, and given to betting, 
would wager it all that I would cause the bees to metamorphose all the egr's that a queen may lay into drones exclusively; nay, I would cause them to be metamorphosed into working bees in March, and into drones in April, and so on alternately, and a few into queens at any time."* This is a point to which it would be well if scientific men would give renewed attention. All the known facts appear at present to favour Mr. Pettigrew's statements.

Although it may appear that as the bees are indued with so much ingenuity, and have so many methods of procuring a new monarch, in place of the one lost, yet it does sometimes, although very seldom happen, that the queen perishes, or is lost, when there are no eg'gs in the hive fit for transformation. In that case the bees appear to lose all their former energies, wander listlessly about the hive and its entrance, collect no new stores of honey, but live upon that which has been already laid up, and when that has been exhausted, either perish of hunger at home, or leave the hive in despair. In such a state, they will, of course, be only too glad to welcome a strang'er queen, but it is recommended instead of giving them a new monarch to give the stock to another hive, when they will at once fall into its ways, and return to their wonted habits of industry and economy.

It appear's that the bees are occasionally subject to mishaps in the process of development from the egg. On one such occasion, when the larva of a queen was concerned, the incident was marked by some peculiarly interesting phenomena. Keys, the author of a very excellent book entitled "The Antient Bee-Master's Farewell" (1796) beheld the whole, and thus recorded his observations:- "I saw the worker's very busy in demolishing a royal cell, close to the window of a box. It had been sealed up some days: but continuing so beyond the usual period of exclusion, I suspected soine mischance, and, therefore, was very intent to observe the result. At five o'clock one morning, the worker's were very deeply engaged in opening the side of the cell; in about two hour's they had made a chasm large enough to :se the nymph, and which they were endeavouring to pull s:t, but in vain. They then proceeded to a further enlargement, when the queen, with hasty steps and anxiotis looks,

* Gardener's Cluronicle, vol. for 18:3! p. 501. 
ns if angry at the delay, began herself the arduous task, the workers remaining quiet spectators. The queen made several violent tug's to disengage it, but her efforts proved fruitless. She then retired, not without an appearance of displeasure. The workers then renewed their attempts, about a dozen at a time, and at intervals ceased to enlarge, while they tried to pull the nymph out, but were still disappointed; for on pulling the nymph upwards she was pressed more into the convexity of the top. Four hours were thus employed, when the queen returned, with like demeanour as before, and proceeded with redoubled efforts to extricate the nymph, but still, unfortumately, with no better success, and finally relinquished the toil with great concern. However, the labourer's resumed the task ot enlargement from top to bottom, which was not effected till near twelve o'clock; a business of seven hours to draw the nymph out. It was full-grown, but-dead!" The explanation given is, that the season having been bad, the wax was formed too coarsely, and much thicker than usual. The royal pupa was therefore unable to extricate herself at the right time, and not doing so, the bees, knowing that she ought to have appeared, were sure there was something the matter, and did exactly what any other sensible beings (bees or men) would have done, opened it to see, and to aid if not too late.

This anecdote appears completely to contradict the opinion of those naturalists who assert, that although the bees do remove the wax from the cell of the royal infant, as the time draws near for it to pass into the winged state, yet they do not do so for the purpose of aiding the imprisoned insect, but merely in obedience to the instinct of sculpturing which is implanted in them, and which induces them to scoop away the wax at the edges of the combs where it is formed into the shape of cells, although the cells are not the eighth of an inch in depth.

We must now take a slight glance at the more salient points of Bee Govervinent.

The "busy" bee, then, is by no means so busy as he ins commonly supposed. He tinds time for leisure and relasi. tion as well as for work. Mr. Grant thinks the bees work in qelays for about six hours, and that sleep duly followis 
libour. He says, "I have come to this conclusion from repreated observation, that in proportion to the number leaving at the early hour of five in the morning, nearly an equal number came in to repose at eleven $\mathrm{A} . \mathrm{M}_{\text {. }}$; and those that left at later hours in the morning, ceased from their field-labours at intervals of about six hours during the day. Those that had returned from labour could be easily disting'uished from the others that had not been out, as the former occupied particular positions until those that were asleep were awakened, and vacated their place to go on duty, and then the others might be seen taking up their positions, and in a short time afterwards were fast asleep." It is interesting to look in upon the hive when the bees are asleep; to see the workers, each with its head and thorax in a cell, giving, in the dilatation of the abdomen, the only sign of life; to mark the queen reposing from the cares of office in the cell of a drone, while the workers form a reverent circle all about her, gently touching her body; or to speculate when the "lazy drone" means to break from his apparently interminable nap, lasting eighteen or twenty hours at a time.

Regular sentinels guard the entrance to the hive, day and night; and these, says Mr. Grant, are relieved with as great regularity as in military life. Very necessary precautions-for the bees, like all other wealthy communities, are particularly liable to be preyed upon by hosts of enemies. There are the terrible corsair-bees, for instance, who, from ill-management and insufficient feeding, cease at last to depend upon their own industry, and live solely by plundering the fruits of the industry of others. And, as might be suspected, when bees do turn to bad courses, they (1) it very effectively. They send out their spies to exploro the country around, and to find out which are the weakest hives. The poor humble-bee is infamously used by these corsairs. They give him no peace at home or abroad. They strip his hive in his absence, and if they meet him in thie fields, they cry, in but too intelligible langmage, "Stand and deliver!" and are obeyed. The humble-bee gives all up, and then, when they let him go, departs, sadly enough no doubt, but patiently, to collect more honey, and hope for better inck in carrying it home. Then, again, there is the 
terrible death's-head moth (Acherontia Atropos), which firghtens most men and women who see it for the first time; no wonder, therefore, that bees are alarmed when they find themselves directly subject to its attacks. This moth appears towards the close of summer, and if it makes its way into the hive commits great ravag'es.

The reader may imagine that as the bees are able to kill and dispose of such apparently impracticable enemies as the slug and snail, they would find little difficulty in destroying the death's-head moth, when it has succeeded in g'aining an entrance into their hives. But such is not the calse, for after it has baffled the vigilance of the guards at the entrance, the bees appear paralyzed as if by some spell. Some writers imagine that a kind of cry, which this magnificent insect has the power of emitting, by resembling the potent voice of the queen-bee, when she wishes to call her unruly subjects to order, has the same effect upon the worker-bees, and for the time causes them to sit motionless, while the intruder is permitted to commit its ravag'es with impunity. It may be as well to remark, that although it is much more plentiful some years than others, the death's-head moth is at all times a much commoner insect than is generally supposed. It is very rarely seen by day, but prefers flying in the dusk of the evening; when it is often taken for a bat. The larva or caterpillar of it is also a night-feeding creature, and during the day conceals itself with great care, but at night it leaves its place of concealment, and commits its ravages unseen. It is almost sure to exist in any potato-ground; but if it is intended to be captured it will be requisite to take a darklantern and enter the potato-field by night, when, by suddenly throwing the light on a patch of herbage, the potatoes may be thoroughly examined without disturbing any other portion. The caterpillar is also not unfrequently found on the common jessamine. If the observer wishes to rear the caterpillar until its transformation into a moth, he must be careful to give it the particular food on which it was living, as the caterpillar hatched on the jessamine will not eat the potato, nor will the potato-caterpillar touch the jessamine. It will require an incredible amount of food during its larval state; and when it has changed into a 
chrysalis it still requires attention. Before it changes, it should be placed upon some damp earth, into which it will speedily burrow. 'The earth must always be kept damp, as otlierwise the case of the chrysalis will become so hared that the imprisoned moth will not be able to escape, when its time arrives for transformation into its winged state. I have in my possession three splendid chrysalides, all of which died on account of the dryness of the eartl, and in two of them the moth was perfectly formed, and ready to escape. I liave also a moth with a perfect body and limbs, but with its wings stunted and shrivelled lilie wet blotting-paper for the same reason. If the hives are jaced near a potato-ground, the owner may be sure that the death's-head moth is not very far off, and will if it can invade the innermost recesses of his hives. But of course the bees do not submit quietly to all this. No, their military genius now shines forth brilliantly. They barricade themselves; they erect formidable fortifications of the most impregnable wax at the entrance of the hive, so that only one or two workers can pass at a time, and the sphinx never. It is worthy of observation, that it is only after. they have suffered that they erect these barricades; and then they only keep them whilst required, and whilst they are productive of no inconvenience.

The waxen barriers constructed by the bees are scarcely formidable enough to keep out such determined and persevering foes as the pirate-bees, wasps, and moths, who are nlways on the watch for a opportunity of gaining the interior of the hive. During the seasons when the bees are most exposed to the attacks of these their insect foes, it will often be found useful to form artificial barriers at the entrance of the hive, so that a single sentinel can guard the door. It may also prove advantageous if the guard, which is usually made of a flat piece of metal placed over the orifice of the live, so pierced as only to permit the passage of two bees at the same time, were made more in the form of a tunnel or tube. A tube is useful because a particularly hungry, or particularly savage marauder-bee or wasp, will sometimes make a bold dash through the scntinels, and make good its entrance in spite of both sentinels and barriers. When, however, it sees a long and 
dark entrance, and cannot ascertain what force is posted at the other end, it will be too much alarmed at the strength of the defences to attempt to break through. We may sce an analogous fact to this in the conduct of one of the solin tary mason-wasps, which to escape the visits of the dreaded ichneumon-fly, as it dig's its hole in soft stone, uses the fragments to build a long tunnel at the entrance of its uest. The ichneumon very soon discovers the nest, and travels round it several times, peeping most cautiously into the dark, narrow passage, evidently in considerable doubt whether the inhabitant of the nest is at home or not. Often the wasp returns from a caterpillar-hunting excursion, and finds its winged enemy hovering about its nest, but afraid to venture its life down the treacherous-looking tunnel. Whatever guard is used at the entrance of the hive cannot fail to incommode the bees, as it will only suffer two bees to pass at one time, and the inhabitants of a strong hive may be seen pouring out from the entrance in numbers. It must, therefore, be made in such a manner that it can be removed at pleasure. When spring comes, and the enemy is nowhere-to them at least-they joyfully clear all away to facilitate the important events of the time. Dr. Bevan mentions an anecdote that goes far to show that bees possess memory and languag'e. A colony had been attacked in 1804 by the sphinx, and suffered through its tardy preparations. In 1807 the moth reappeared, when the bees immediately constructed fresh ramparts. Now, working-bees do not live more than a year at the outside, therefore the particulars of that awful year must have been conveyed from generation to generation, or the queen must have reigned over the hive from 1804, and have been the means of rousing the community of 1807 to the danger they experienced. Language and memory appear equally indispensable in either case. Beside the sphinx, the honey-moth and the honeycomb-moth attack bees, and more cunningly than the splinx, as well as more successfully. They are so small that they can get into the hive sometimes, notwithstanding the vigilance of the guards, and deposit their egg's in the combs.

These little moths, called galleria moths, are small, of a light brown colour, and can run with great rapidity. When 
they are at l'est, or when running, their wide wing's ars folded over the body into a very small space indeed, and offer no impediment to the movements of their feet. It is, indeed, necessary that some provision of this nature should be made, for when one of them has succeeded in slipping past the sentinels, there is a grand commotion in the hive, each bee chasing the galleria moth, and endeavoured to secure it with its teeth, when its fate would be instant death, at the jaws of the infuriated multitude. But g'enerally the active little creature having once obtained an entrance, fulfils the object for which it came there; for after running and doubling and twisting about among the combs, it evades its enemies, and secretes itself in some crevice, where it deposits it eg'g's in safety. The object of its life is now accomplished, and it cares little what becomes of itself afterwards. As for the hive, the mischief is done, for the eg'g's are sure to be hatched, and successive colonies of these destructive little creatures are soon found, some of whom rush out of the door to carry destruction into other hives, while others, finding themselves in the midst of plenty, lay their egg's in the same hive where they themselves were born. Atter all this labour and perseverance, what a strange place this seems for a mother to choose, and what a chevaux de frise, as it were, of sting's all about her pretty ones! It matters not, however, to them, as she well knows. The larva, once successfully hatched, rapidly covers itself with silk, which the bees cannot destroy nor penetrate with their stings for the destruction of the noxious intruder. Gradually this silken covering becoms a tube or covered way stretching in any direction that the larva pleases right through the combs. When this enemy becomes numerous it is all over with the hive; the bees have no choice but to desert the place altogether, and construct a new habitation.

No precaution should be neglected which can keep out these tiny but most destructive foes. When they lhave once made a lodgment in the hive, their silken tunnels ramify in every direction like the various lines on Bradshaw's railway-map. Their voracity is almost incredible, and the power of their jaws quite extraordinary. Wishing to be able to place before the eyes of entomologists the comos of bees in their 
various stages, from the first sculptured block to the black and worn-out comb, I placed a series of combs in a plass case, protected with plenty of camphor, and also placed in the same case a number of humble-bee, wasp, and hornet combs, as further illustrations. My labours were, however, soon rendered abortive by these most provoking insects, who in an incredibly short time had driven their tunnels through every comb, for the sake of the honey and wax. They first devoured all the ordinary combs, including many cells filled with bee bread, and a few where pupa bees had been suffered to die, they then turned their attention to the coarse, tough cells of the humble-bee, and finished them, and lastly ate up even the paper cells of the hornet and wasp, leaving nothing. behind them but a few fragments hanging on their silken tubes. For tobacco smoke they cared not a jot, and sulphur only caused them a temporary inconvenience. A solution of corrosive sublimate, dissolved in spirits of wine, destroyed all those who were alive, but their place was speedily supplied by others newly hatched. These creatures take care to expose no part of themselves out of their habitations except their head and neck, which like that of the caddlis worm is hard, and impenetrable to the attacks of their enemies.

As to the internal government of the bee-community, Mr. Grant states there are some bees that appear never to work themselves, but take regular rounds to ascertain whether all bees are performing their duties satisfactorily : but it is probable that these officers or magistrates of the hive, may also, like the sentinels, fulfil their high duties only in rotation. And sad enough these duties occasionally are-involving no less than penal judgments. Mr. Grant beheld "two bees brought out of the hive by other bees, assisted by one on each side as guards: they were evidently condemned criminals. They were thrown down in front of the hive, stung to death, and then the executioners returned to the hive as though conscious of having performed a highly praiseworthy duty." $\mathrm{He}$ supposes these unfortunates to have been either strangers or unruly members: but as this involves a serious point of the bee criminal jurisprudence, we had better suspend our judgments until the facts are made clearer. Perhaps the criminals were a pair of the corsairs 
recently descrived. As to the bee-police, we shall content ourselves with the illustration afforded by an anecdote. "A few pounds of honey had been taken from a hive by its owner, and placed in a closet of a room of which the dloor was closed. The bee-police, however, appear to have been following the stolen goods, and watching their opportunity, stole in through an open window into the room, and thence by means of a crevice into the closet itself. How the bees must have enjoyed the sport as they hurried to and fio until they had completely emptied the abstracted combs, and recleposited the whole of the honey in the centre of the hive: their own once more!"

Bees appear to be decidedly backward in surgery and the medical art, and probably kill their sick and maimed, when the cases are too difficult; but then they take care to have few of such cases. They are your true sanitary labourer's. See how carefully they clean the floor of the hive at every favourable opportunity; how they remove all decaying or dead exuviæ. They take the greatest care that none of their own exuviæ should fall upon the floor of the hive, and always discharge it outside. To such an extent is this practice kept up, that after the winter season, the bees may be seen leaving the live for that express purpose. It was necessary, some years ago, to destroy a hive during the winter. I preserved a large number of the bees for dissection, and did not find one, where the intestine was not enormously swollen, and in some cases so much so that it appeared almost impossible that the insect could fly at all. Then they can also ventilate in hot weather. But that process deserves a few words of explanation-it is at once so interesting' and unique. The ventilating' bees take up their position in two bodies, one larger than the other, near the entrance, but so as to cause no interruption of the way. The small body near the door turn their heads inwards, the other and larger, standing farther within, look towards the entrance of the hive. The bees then uniting their wings together by means of small marginal hooks, so as to increase the surface, move them to and fro with such velocity, that the wing's almost cease to be distinguishable. This is hard work, and has to be continued incessantly at certain periods, so the ventilating corps is renewed all the 
more frequently, that is, at intervals of about twenty-five minutes.

Those who have been in India will easily recognise that their indispensable "punkalı" is only a modification of the mode of ventilation, which has been used by the hive-bee for countless years. The exertion of fanning is so great that the bees are forced to support themselves very firmly by their feet and claws. Ventilation, although most frequent in hot weather, is carried on to a certain extent, even through the depths of winter, as the object of the bees appears to be not so much to reduce the temperature, as to change the air of the hive.

Wonderful as this power of ventilation may be, these singular insects possess a still more extraordinary power, that of increasing heat at will. There are some periods when the temperature of the hive is absolutely required to be much higher than at other times. Just when the infant bee is about to burst from its cell, the heat of the hive is considerably raised, as the young bee when it emerges is peculiarly sensitive to cold, its soft, sleek body perspiring most profusely, and covered with moisture. Immediately upon leaving its cell, it instinctively makes its way to the thickest throng of bees, and eagerly seeks for that warmth which is necessary to bring its feeble body to its proper tone, nor is it until after the lapse of some hours that its body attains sufficient firmness to render it independent of the external heat derived from the bees in the hive. The necessary amount of caloric is furnished by that portion of the worker-bees called nurse-bees, and the manner in which it is managed is told in the following extract, taken from Mr. Newport's report of his experiments on this subject:"These individuals," the nurse-bees, "are chiefly young female bees, and at the period of hatching. of nymphs they seem to be occupied almost solely in increasing the heat of the nest, and communicating warmth to the cells by crowding upon them, and clinging to them very closely, during: which time they respire very rapidly, and evidently are much excited. These bees begin to crowd upon the cells of the nymphs about ten or twelve hours before the nymph makes its appearance as a perfect bee. The incubation cluring this period is very assiduously persevered in by the 
nurse-bee, who scarcely leaves the cell for a single minute; when one bee has left, another, in g'eneral, takes its place. Previously to this period the incubation on the cell is performed only occasionally, but becomes more constantly attended to nearer the hour of the development. The manner in which the nurse-bee performs its office, is by fixing itself upon the cell of the nymph, and beginning to respire very gradually; in a short time its respiration becomes more and more frequent, until it sometimes respires at the rate of 130 or 140 per minute." In further experiments on this subject a common humble-bee was confined in a phial containing. three cubic inches, and was found by its violent excitement consequent on being thus imprisoned, to have added no less than four degrees of the temperature to the air in the bottle in a space of five minutes. As, therefore, violent excitement produces heat, so inactivity causes heat to be lost, and on that account, the temperature of hybernating bees is very low. According to Mr. Newport, the contradictions of former observers respecting the heat of the hive during winter is easily accounted for by this power of changing the temperature at will. When the hive is at rest, the temperature is usually only a few degrees above that of the external atmosphere, but if the inhabitants are disturbed, the temperature immediately rises. The swarming season, of course, renders the hive extremely hot, as almost every bee, particularly those who intend to form the swarm, is in a violent state of excitement. In one experiment, when the temperature of the external atmosphere was $34 \frac{1}{2}$ degrees, the temperature of an undisturbed hive was found to be $48 \frac{1}{2}$ degrees, while that of a hive whose inhabitants had been thrown into a state of great indignation, by tapping on the exterior, speedily rose to 102 degrees.

These experiments among other things serve to show that we need not trouble ourselves very much about the temperature of the hive, either in summer or winter, as the bees can either raise it if they are too cold, or lower it if they are too hot; while, however, they can bear a rapid change from cold to heat as was above mentioned, they cannot bear a sudden change from heat to cold. If in the depth of winter, a hive is tapped, a bee comes out to see what is tho 
matter, and if it is dragged into the cold air, it dies instantly.

\section{THE MANAGEMENT OF BEES}

Can be bet understood by a careful study of the habits of the insect; and therefore it is, that, independent of the interest we wished to inspire in the proceeding's and modes of life of a most attractive little community, we considered it advisable to preface any necessary practical details, by dwelling at some length on the phenomena from which alone can be derived just principles of management. Study Nature, and she will herself show you where-and howyou may occasionally assist her when she requires assistance in the attainment of your especial object; but never attempt to conquer her, or to turn her completely aside from hel own path. In other words, leave the bees as far as possible to their own instincts, by accommodating all your requisitions to their habits. This cannot be done by following. implicitly mere dogmatic instructions, derived from other men's experience, capable with them, no doubt, of being: adapted to changing or unexpected circumstances, precisely because based on experience that is ever ready to correct and inform the ideas it sent forth, but which to you, wanting that experience, may fail at your utmost need. We shall not, therefore, crowd these pages by very long, minute details of bee-management. Of course there are some points of practice easily explained, not liable to the dang'er we have pointed out, and indispensable to the young beginner in beekeeping. These we shall endeavour to state clearly and efficiently. But for the most part all the details of beemanagement can be best learned from practice, and the study of the essential objects which details are intended to stcure. It is also to be observed, that such details are unsettled to this hour, and vary among the best apiarists.

Almost the entrie success of bee management depends upon the capabilities of the apiarian to take advantages of all the various chang'es which must take place according' to the variations of temperature, locality, and seasons. While, therefore, it would display great presumption on the part of a beginner to dispense with the rules which the extensive ex- 
perience of veteran bee-masters has enabled them to lay down, it would also be the mark of a mind rery contracted and deficient in resources, were he slavishly to follow these rules without deviating from them, when circumstances would point out that a different course must be adopted Great caution must be observed in acting on new principles. Many treat their bees as if they were utterly insensible beings who cared not the least how they were lodged or fed, and who fancy that they can manouvre a hive of bees as easily as they can a flock of sheep. Bees must be treated according to their instincts, and if constantly thwarted by the ignorance of their master, will never thrive properly. Indeed, a man who hopes to get a decent harrest from his hives, and at the same time to manage them on a wrong: principle, will effect about as much success as a gardener might who strove to improve the quality of a peach by grafting it upon a strawberry. The principle of grafting' here is right enough, but the application is wrong. So if a man learns any number of correct ideas from books, yet if at the same time he does not learn the application, he will do but little good.

So with regard to the much vexed question of theory and practice: a mere theorist will never succeed in securing any particular harvest, while the narrow-minded man who rests lis whole hopes upon acting in precisely the same manner in which his father's acted, will never advance the culture of bees one item. To make a perfect bee-master, then, practice and theory must be united-the theory sound, the practice decided. And this is a point that cannot be too closely attended to. When the apiarian has made up his mind to adopt any particular course, he must carry out that determination in a most decided manner. And here I may remark, that to learn by heart a number of instructions respecting. any operation upon bees-say living a swarm-and acting upon those instructions, are two very different things. When, after carefully committing to memory certain rules, the young apiarian goes out, hive in hand, to attack a swarm which has just settled on a branch of a tree, he naturally finds a slight misgiving steal over his mind as he approaches the living mass, and gets within rang'e of the strag'gler's that are dashing about with a very ominously sharp 
hum, that appears to his mind very sugrgestive of sting's, and canses him to assure himself of the exact locality of his bottle of hartshorn. However, he nerves himself for the attack, recollects that the hive is to be placed below the swarm, and then a smart tap is to be given to the branch. So he sprinkles sugar and beer in the hive, places it under the swarm, takes a very long stick, and standing at a respectfill distance, administer's a rather feeble tap to the fatal branch. No effect is produced, and he gives another tap rather more powerful than the last. The obstinate bees still remain fixed to their branch like a quaker's hat to his head, and no perceptible effect is produced excepting a kind of general movement in the swarm, which appears to indicate an intention on the part of the bees to hold together rather closer than before, Having now gained some courage, he once more uplifts the stick, and permits it to descend upon the branch with rather more violence than in either of the former assaults. Down go some hundred bees or so into the hive, where they are heard buzzing away in a most frantic manner, and filled with indignation at the unceremonions manner in which their wing's are clogged with the sticky compound in the hive, while the remainder rise in a disturbed mass from their branch. The terrified bee-keeper, losing all the remainder of lis presence of mind, throws the long stick at the swarm, and takes to his heels, too happy to find any place of refuge from his winged foes. In a few minutes he emerges just in time to see his swarm disappearing over his hedge, and in a few minutes the vigorous tinkling's of keys and warming-pans assure him that others are engaged in the pursuit of the hees which he has permitted to escape. Next time he remembers that if the swarm be intended to fall into the hive, the branch must be struck very sharply indeed.

In this as in every other occupation, great decision is necessary, as the bees are very irascible creatures, and any fumbling about their dwelling's or themselves irritates them marvellously, while a bold and rapid course of proceeding appears to astonish them out of the power of doing injury. Indeed it is said that a skilful operator can turn up a hive and cut out combs with impunity while the bees are hard at work within. One bee-writer remarks that single bees if bolchy caught in the hand will not sting. Before trying 
the experiment I would, from experience, recommend tho experimentalist to have his bottle of hartshorn quite ready, as it will in all probability be placed in immediate requisition.

Perhaps the best course is to let a veteran apiarian perform a few necessary operations on the hive while the novice looks on and discerns how the skilful operator, caring no more for the bees than for so many bluebottles, and treating the hives as unceremoniously as if they were milk-pails, by a few quick and decided operations effects more in half an hour than he himself would in a day. Only whatever instruction he receives from the veteran in question, let him never learn one thing of him - to destroy his bees with sulphur, or, as they laconically but too accurately term the butchery, to burn them. If he did, he would deserve to spend a few minutes in the agreeable subterranean passages in Dover Castle, with the brimstone shoots properly dressed with sulphur and lighted charcoal.

There is another caution which is necessary, and that is if you take up some particular hobby, as you certainly will if you are really enthusiastic on the subject, do not ride it too fast. It is astonishing how people deceive themselves when their hobby is called in question. For instance, one celebrated bee-fancier made wooden hives his particular hobby, and utterly decried all varieties of straw, finishing his argument with a triumphant query as to whether bees when in a state of nature preferred a hollow tree, or a truss of hay for a residence-forgetting in the exuberance of lis enthusiasm that trusses of hay are not generally found in those comntries where bees hive in a state of nature, and that if they were, it is very seldom the case that a truss of hay contains a hollow large enough for a hive of bees to repose themselves in. It would, however, be an interesting experiment to place in those forests of America where the wild bee is found several straw hives, in order to see whether the bees would take to them, as wrens will take to an empty pumpkin or a little box with a hole in the side.

Having now detailed a few of the measures to be pursued in bee-management, we will proceed to a still more pleasing occupation, that of ascertaining what may be the 


\section{PROFITS OF BEE-KEEPING.}

Before commencing this part of the subject, it will be as well to give a brief description of those technical terms which are in common use among apiarians, as many young beemasters have been sadly puzzled to comprehend the instruction given in bee-books. By a "stock" is meant a hive of bees at the end of the season, after all possibility of swarming. is grone. A swarm that has taken possession of a hive, and in its turn sent forth another swarm, is called a stock, without reference to the length of time during which it has inhabited the hive, as being the stock from which the swarm was sent. Hives that have been introduced into their habitations, and have not thrown out swarms, are themselves termed "swarms" until the end of the season at Michaelmas, when they are advanced to the rank of stocks. "Colonies" are those bees living in double or treble hives.

Sydserff supposes, in an estimate that we shall try to make clearer than he gives it, that every swarm or stock may produce another annually for sale, whilst the entire number of the stocks kept in hand shall be doubling yearly, which can only be accomplished thus:-

1st year-1 stock produces 2 , making 3 in all;

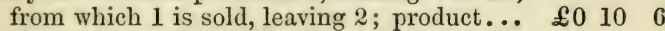
2nd year-2 stocks produce 4 , making 6 in all; from which 2 are sold, leaving 4 ; product.. $\quad 1 \quad 10$

and so on. The expenses of the hives being defrayed by the honey obtained, what will be the result in fourteen years? Why that the last of the fourteen would produce 4,300l. 16.s. from 8,192 hives! We wonder whether Sydserff ever asked himself how many apiaries could be doing this at the sane time in England, and still obtaining $10 s .6 d$. for each hive? A less amusing but much more useful calculation would be, to see what could be done by relying upon keeping your stocks yourself to produce honey, which can always be sold, and which would probably be much more largely consumed if it were cheaper. Here is a wide open field for skill and enterprise. All apiarians are agreed as to the profitable nature of bee-keeping. Bees in good pasturage, well managed, will give two swarms yearly; and, in favourable 
seasons, the first swarm will the same year give one or tro riasses of honey. No noticeable capital is required to commence; no noticeable amount of time is necessarily consumed in their management, and they may be kept almost anywhere, though not with equal profit. One apiarian, whose authority may be depended upon, gives the profits of eight stocks only as averaging about $20 l$. in three successive years. Another, who was regularly engaged from six to six daily in other avocations, clea? ed nearly 100 l. in one year by his bees. The quantity of honey that may be obtained from a hive is exceedingly variable, but offering, therefore, only the greater assurance of due rewards for able management. Fifty or sixty pounds liave not unfrequently been obtained from a single hive in a season, and occasionally as much as $100 \mathrm{lbs}$; whilst from a set of collateral boxes, $110 \mathrm{lbs}$. is mentioned; and Cotton states that as much as 210 lbs. have really been stored in a single season, by a single stock similarly situated in a roomy trebled habitation. The prices of honey in London are stated to be generally as follows:-

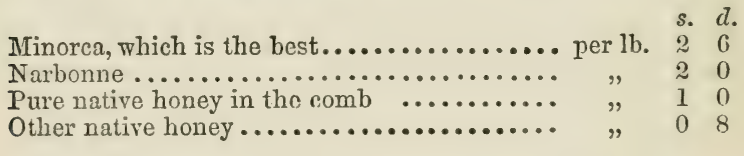

But pure native lioney in the comb, obtained in glasses, is sought for the table, and therefore often sells for double the price above-mentioned. We shall only add, that Mr. Smart, a well-known apiarian, considers hunareds of stocks may be liept where only tens are now to be found, so far as regards the capalilities of support, the main point to be considered. To that subject, therefore, we now turn :-

\section{BEE-FLOWERS.}

Conspicuous among all the plants loved by bees (for the best of reasons, that they get the most honey or other substances from them), are clover, wild-thyme, heath, and broom, borage, French buck-wheat, and Metilotus lencantha. This last may be useiully grown for the bees' especial gratification. It is easily cultivated, blooms from June to 
November, and is ornamental, in addition to its other good qualities. But the most important qualification of bee-pasturage is, that there shall be always something for the bees, from the very enrliest spring to the very latest autumn. It will be useful, therefore, to append a

\section{IIST OF BEE-FLOWERS.}

Spring.

Erica Carnea*

Winter aconite**

Rosemary*

Laurustinus

Hazel*

Snow-drop

Crocus*

Willow*

Osier*

Primrose

Hepatica

Violet

\section{Syringa}

Helianthemum

Annual poppy*

Sea-kale

French willow

Sweet-briar

Bean

Yellow lupine
Almond

Wallflower* (singie)

Borage*

Onion

Gooseberry

Apricot

Peach

Apple

Gooseberry*

Currant*

Laurel
Turnip*

Cabbage, \&c.*

Strawberry

Tulip

Hawthorn

Gorse or furze

Columbine

Taburnum

Berberry*

Ribes Sanguineum

Dutch Clover*

\section{Summer.}

Mignionette

Blackberry

Chestnut

Mallow

Lime*

Hyssop

Teazle

Nasturtium
Yellow vetch

Sainfoin

Broom

Wheat

Viper's bugloss

Raspberry*

Symphora

Racemosa

\section{Autumn.}

Michaelmas daisy

Winter savory

Purple houseleek

Ivy

Honeysuckle
French buckwheat, * Heath* sowed at Midsum- Sunflower mer

Spanish broom*

Hollyhock*

\section{Lemon thyme*}

St. John's-wort

Melilotus leucantha*

Those marked with an asterisk are understood to be the flowers especially favoured by the bees. What a choice little garden for himself, as well as for his bees, the apiarian may make from the above list, if he does not choose to leave the bees dependent upon the stores of the neighbourhood at large! 
Should the surrounding neighbourhood not furnish a sufficiency of flowers, the practice of transportation, or shifting, is strongly recommended by many authors. It is not in the power of every bee-keeper, but as those whose home is placed by a river or canal, have a means at hand for transportirg their hives, I have chosen to mention it here. In some countries, boats are built expressly for this purpose. They receive a very large number of hives in each boat, and by travelling for a few hours at night, the bees find themselves in a new country during their working hour's, and the hives are rapidly filled with honey and wax of the best quality. The boatmen receive a small sum for each hive that they transport, but I rather fancy that their ingenuity does not rest until it has extracted some portion of the honey from the best filled hives. The Nile is much used for this purpose, and bees traverse the entire length of Egypt during. the summer. In China ducks are subjected to the same migratory life, and thrive amazingly. Hives may easily be carlied on men's shoulders, as that mode of conveyance shakes them less than carriage by waggon. Heaths are the best places that bees can possibly live in, and in Scotland there are people who make their living by taking care of hives during the time that the heath is in blossom, a period of about two months, for which time a rent of from one shilling to eighteen pence is paid by the proprietor. It is always necessary while the bees are migrating, to take them at least ten miles during the nocturnal journey, as they are otherwise apt to fly back to the former position of their hive, and to lose themselves in searching for it. The distance to which bees can fly for food is shown in the following anecdote, which has been recently published :-

"A man who kept bees in Holborn, and wishing to find out where they worked, sprinkled them all with a red powder as they came out of the hive in the morning. As the heath and thyme were now in full bloom, he at once thought that Hampstead, being the nearest heath, would be the likeliest piace to find his bees. As soon, therefore, as his bees were gone away, he hastened to the heights of Hampstead. The walk was a long' and toilsome one, of at least four miles, in a July sun. But he trudged manfully on, soon left behind him Camden and Kentish Towns, 
and at last was refreshed with the soft summer breeze sweeping across the purple and golden bloom of the heath. After a few minutes' rest on the green sward, he began his search, and before long was delighted to find there, among. thousands of other busy bees, his own little fellows in the dusty red coats, which he had given them in the morning." Many of the bees made the journey more than twice in each day, thus piloting themselves through sixteen miles of smoke and dust within the twelve hours.

If the hives are taken by water, they should always be placed on the shore at some distance from the bank, before opening the doors, as they will very probably when returning home wearied and laden with their burdens fall into the water, before they can reach the hive. If the hives are placed for the season, they should be kept at some little distance from other hives, as if they are weak, their more powerful neighbours will inevitably plunder them.

\section{COMMENCEMENT OF OPERATIONS.}

And now, gentle reader, we will venture to suppose you, as an admirer of bees, or of the profit that may be derived from them, are determined to commence operations in a quiet careful way, that shall give you an opportunity of learning; by the management of a few, how to deal successfully with any number.

The first thing to be done in commencing operations, is of course to procure your bees. This can generally only be managed by purchase, and, in that case, follow the recommendation of Boswell :- "It is with a beehive as with a wife, never take one on the recommendation of another person." In order to enable the intending bee-keeper to effect this important point in a satisfactory manner, a few simple observations are here given. The best time for purchasing is in the spring, when the purchaser should carefully watch the proceedings of the bees belonging to the hives which he intends to purchase. He may be assured that thing's are going well, if the bees pass rapidly to and from the hive, many of them bearing their baskets of yellow pollen upon their leg's. If the examination is made before swarming, particular attention should be paid 
to the number of drones, as if they muster strongly, the hive is sure to be a populous one.

If it is spring when you commence, purchase a recent swarm just comfortably settled in a new hive, weighing" not less than four or five pounds, and for which you mity pay, perhaps, ten shillings. This will be a first swarm, second swarms seldom weigh more than two pounds. If it be autumn, your best way will be to obtain a swarm of the same year, with all its "plant," as the commercial men say, of combs and brood; in short, an established but still young colony. This should weigh from twenty-five to thirty pounds, and contain, according to the apiarian's not very flattering or poetical mode of calculation, about half a bushel of bees. For this you will not pay too much by an expenditure of twenty shillings. If you buy a colony of older date, you know not how undue may be the proportion of the "plant" over those who are to work it, and must not trust to weight alone in a stock-hive; but see that the combs are of a pale colour, as dark ones show ag'e, that they are worked down to the floor of the hive, and that the interstices of the combs are well filled with bees. These important particulars may be easily learned by gently turning up the hive at night when the bees are at rest.

If the footboard of the hive is not purchased at the same time, it will be found advisable to separate the hive from its footboard by small wedges some few hours before it is intended to be removed. This precaution will prevent the bees firom clustering on the floor, and will drive them to take refuge among the combs, together with which they are easily moved. The hive can then be placed upon its new footboard, and removed with it. Of course the entrance must be kept carefully closed during the process of removal, as the bees are generally very indignant at the unceremonious treatment they are experiencing, and if they should escape would soon use their sting's with considerable effect. A piece of perforated copper, or tin, fixed against the entrance will readily effect this object, and at the same time afford sufficient ventilation. Bevan also recommends that if the purchase is made in autumn, and the hive should be full of honey, it would be safest tw 
carny it in an inverted position, to avoid the risk of detaching the heavily-laden combs. If the purchase is made in autumn, ascertain that the massacre of the drones has taken place, as if this has not happened there is something radically wrong in the hive. In all cases the massacre of the drones is a certain sign that no more swarming is intended for that season. Never put a swarm into an old hive, as it will be almost certainly infested with vermin, and particu. larly with the eggs of the insidious honey-moth, who will be ready enough to attack the hive, without having its eg's's introduced where they can, as soon as they are hatched, set nbout their marauding incursions.

\section{WINTER MANAGEMENT.}

Supposing you commence in autumn, this will be one of the first thing's on which you will be anxious. First, as to their food; second, as to their protection against cold. If bees require feeding in the winter, it is because they have been wrongly deprived of the very stores they had laid by for that season. One of the advantages of all systems of double or treble hives, as we may call the junction of two or three hives or side-boxes together-in teclnical lang'uagee storifying-is, that they allow the central or chief portion of the colony to remain permanently undisturbed, so that there is always food in it for the bees when required. If a hive weigh less than twenty pounds at the approach of winter, food should be given at once, so that there may be no disturbance in the hive in the periods of frost. The most natural of all modes, is to lay a piece of honeycomb in the hive about October or Norember. If that be not readily obtainable when wanted, honey in a plate will do, with short straws over it for the bees to alight on, or good sugar mixed with boiling water in equal weights. If necessary, the hive may be raised, to receive the plate or comb, by an eke-that is, a hive prematurely cut short, us it were, in the construction, at three or four rounds. This fits exactly the bottom of the hive, and forms a continuation of its edges. It will be good economy to repeat this feeding in spring, when the bees begin to stir about, but find the flowers not so early as themselies. The fool in 
spring is placed, by some keepers, outside the hive, under the protection of an empty hive, or any other suitable cover. The policy of this advice is very questionable, as if the food, whether honey or sugar, is exposed outside the hive, the robber-bees are sure to find it out; and there will, in all probability, be a constant warfare going on between the bees for whose benefit it was intended and the bees who intend to benefit themselves dishonestly. All this feeding, however, is quite unnecessary where bees are regularly well managed, and the hives have grown strong.

Feeding the bees by any process which requires the hive to be turned up, is at all times but a clumsy expedient, and amore so, if feeding is required in winter-time, as if bees are suddenly exposed to severe cold they die instantly. To put a piece of honeycomb inside the hive is certainly the most natural plan; but as that cannot be done without turning up the hive, some other method must be discovered. There have been many most ingenious devices invented for this important purpose. Some hives are made with moveable drawers in the footboard, in which a saucer full of honey is placed, of course properly guarded by perforated card, or other material, and then introduced into the bottom of the hive. But to make the feeding apparatus as natural as possible, we must remember that the honey for the winter is not stored upon the floor, but in combs hanging from the roof, and we must, therefore, attempt as far as we can to imitate nature. The next best plan, as we cannot in most cases actually suspend a comb for the bees, is to place their food at the top of the hive, and not at the bottom. This, of course, cannot be done in an ordinary straw live; but in any of the carefully-made capped hives, whether of straw or wood, it is easily managed by placing the food upon the top of the hive, withdrawing the cork, or whatever obstacle is placed to prevent communication with the upper part of the hive. The, bees soon find out their food, readily ascend, and carry it away into their combs. In this case no bees but those of the hive can obtain access to it, and the important point is also gained, viz., that of scarcely diminishing the temperature of the hive.

As to the form of the feeding vessel, each bee-keeper 
will probably invent his own. Those which are intended for the top of the hive generally have a hole through the centre to correspond with that which forms the communication with the cup or bell-glass, and through which the bees ascend. One form is that of a flat wooden basin of a soup-plate form, with a tube through the centre through which the bees pass, and a great number of concentric circular channels cut around the tube, the hollows of which were filled with honey, so that the bees could safely sit upon the ridges while they sipped their food from the channels. Perhaps the most ingenious plan is that of a French bee-keeper, who manufactures a paper comb, and places that upon the hive, so that the bees can take their honey almost as if they were drinking it out of real combs. Tire only difference is that the cells of the paper comb are cylindrical instead of hexagonal.

With regard to the material with which they are to be supplied, their natural nutriment honey, is, of course, the best ; but care must be taken that it has not been removed from a hive by means of sulphur, or the bees will be made most seriously ill by the tainted food, and probably lose many of their number. Above all things, take great care that the honey is not candied; it not only is actually poisonous to the bees, but they also have often perished from daubing. themselves with the candied honey, which they have indignantly cast on the floor of their hive, and through which they must pass whether they enter or leave the hive. Sugar, mixed with boiling water or beer, is an excellent substitute for honey. The best way of making this pseudohoney, is by dissolving a pound and a half of sugar in a quart of ale, boiling it gently for about five minutes, carefully skimming off the scum. Some prefer adding a little salt when it is presented to the bees. If a real comb cannot be procured, or an artificial one take up too much time iri making, a piece of thin wood or pasteboard, pierced full of holes, and laid on the surface of the food, will float there, and enable the bees to get at their food without daubing themselves in their attempts to feed. 


\section{THE HIVE.}

This should be formed of some material that will neitley readily receive and conduct the summer's heat to the hive, nor radiate its own heat away from it in winter. Straw and wood are both good non-conductors of heat, and are both much used. The common straw hive answers every purpose when bee-management in its simplest shape is desired; and if a more elaborate system is to be pursued, the same straw live is easily made the chief portion of a larger structure, having conveniences for facilitating artificial swarming, o? preventing swarming altog'ether, so far as it can be prerented, or for removing the honey. The straw hives have one advantagre over those of wood; they admit freer passage of air by insensible degrees into the hive, and of moisture ont of it. It will save the bees time and trouble, which to you mcans honey, if you take care the inner surface of the straw hive is carefully freed from all roughnesses. India matting has been used with success for lining straw hives. But use no paint, nor washes, nor anything of the kind.

The ordinary bell-shaped straw hive is of course not to be thought of, but it may be made the foundation of an excellent single hive by an hour's work. About one quarter should be cut from the top, and upon this a flat thick piece of wood be fastened, projecting about half an inch all round. In the centre of this wooden top, bore a hole with a large centre-bit, and you have the body of the hive. The lower rim of the live should be protected by a wooden hoop, in which the entrance is not to be cut, but out of the substance of the footboard, which should be as thick as can conveniently be obtained, and always of wood. A bell-glass will go over the hole in the top of the hive, and a smaller live of straw, or a wooden cover will protect this and keep it dark, for the bees cannot bear light to intrude upon their labours. The hole should be kept closed with a bung until the bees begin to bang. about the entrance of the hive, when the bung should be withdrawn, and the bell-glass with its cover be placed upon the hive. The bees finding more space for their labours will. at once turn their attention to the interior of their hive, and the bell will speedily be filled with the most beautifully puro 
honey. When this is the case, a piece of thin metal should be slipped between the glass and the wooden top, so as to cut off the combs from their attachment to the floor, and at the same to prevent the bees in the interior from escaping" when the glass is removed. This should not be done immediately, as the queen may be among those imprisoned in the glass, which will be known by the quiet behaviour of the bees already in the glass. If they become excited, the queen is sure not to be among them, and the glass may be taken off, and its place supplied by another. The full cap, being instantly wrapped in a cloth, should be taken to some distance from the hive, and on the removal of the cloth the imprisoner bees will take the opportunity of regaining their home. A cap thus treated may be sold at a high price, as the comb will contain no eggs, young, or bee-bread, and also forms a very pretty ornament to the table. I knew one case where a lady, a bee enthusiast, took a cap nearly three feet in height full of pure honey, and was so charmed with it that she kept it as a spectacle, and never could prevail upon herself to empty it. If this plan be adopted, the bees will find plenty to do, and you will not have a swarm until the hive is so strorg that it can easily spare it, and at the same time the original stock of honey in the hive will be untouched, and may possibly afford another supply, although not quite so pure.

Another very excellent way is to form the top of the hive of loose bars, instead of a solid board. This not only admits of capping, by placing over the bars a board perforated in the usual manner, but allows the bee-keeper to remove any comb at pleasure. This is a most useful power, as old combs can in that manner be removed, or unsound portions cut away without disturbing the remainder of the hive. Each bar should be loosely placed in notches cut in the top of the hive, and always laid from front to back. The bees can be easily induced to follow the direction of the bars by placing a piece of gruide-comb upon each bar. This is done by toking a piece of pure, clean comb, some of which should always be kept for the purpose, rubbing it on a smooth piece of iron, and then immediately pressing on the bar, to which it will adhere with tolerable firmness, and the bees will of their own accord fix it quite tight. This should be done to 
each bar. A small piece of comb will suffice, as all that is required is to give the bees the direction in which to work. The comb must be carefully cut, in order to preserve its original inclination. The distance of the bars from each other should be about half an inch, and their width one inch and one-eighth. These proportions should be carefully observed, and then ample room will be given for the variation in the thickness of the comb that bees constantly produce. The brood cells, as they are to hold young bees, are always the same depth, but the honey or store cells are often lengthened very considerably.

The power of thus removing a single comb will be found most advantag'eous when the comb begins to blacken by age. After a few years the successive generations of young. bees leave so many of their exuviæ and shrouds in the cells, that they become too small to receive young any more, and are often used for containing honey. 'The honey of these cells is sure to be very poor, and they hardly contain any wax at all. I have now in my possession several series of silken cocoons which I have taken from old cells. They fitted one inside another, like a series of thimbles, and were easily withdrawn after a careful maceration.

The hive should always be placed upon a stand of a single log, the footboard projecting as far as possible, in order to keep off mice, rats, and other vermin. Care must be taken that when the wooden top to the hive is first fixed, all space between the straw and the wood should be carefully tilled up with putty, or better with Roman cement, or the bees will fill up the spaces themselves with propolis, and waste much time in so doing. 'The same remarks will apply to the wooden hoop at the bottom of the hive, which should also be carefully smoothed so as to fit the footboard as closely as possible.

A Glass Wrndow should be let into the back. This is not merely an agreeable adjunct, as admitting you when you please to a certain degree of familiarity with the bees, but often proves of use in questions of pure business-management. Bees, however, if they courteously answer your courteous mode of approaching them (which is, by gently breathing. only through your nostrils, and with an easy nopchalant air, that seems to say, I don't care for the bees, and they have 
no reason to care for me), if they endure your society, they will hardly flatter you so much as to like it; therefore disturb them as little as possible, and never uselessly. You may have occasion to turn up the hive, to examine the interior, or remove a part of the contents; but this must not be done after the flower season is past, for the bees can no longer collect propolis to renew the fastening you will have destroyed,- - that by which the bottom of the hive was securely fixed to the board on which it stands: an indispensable provision against winter cold.

As to protection from cold, bees in good hives really need none beyond what is afforded by freedom from damp and severe winds, shutting out the direct rays of the sun in winter and early spring, and, above all, by taking care that they are not left too few in number to keep up the natural heat of the hive. This appears to be their own mode of protecting themselves. As the weather grows more and more severe, they draw more and more closely together into the centre of the hive to create their fireside, towards and from which all the bees approach and recede in fair and wise rotation; whilst, on the contrary, as the cold decreases, they again expand in proportion. They are not, therefore, torpid, or not regularly so, at least. Of course, they do not work, nor do they in winter itself appear to eat, except in periods of unusual warmth, which stirs alike their limbs and their appetites. The judicious apiarian will see that the less frequently these untimely movements occur the better it will be for the bees and for him.

Some bee-keepers recommend that the entrance of the hive should be narrowed towards the winter, and that in November it should be closed altogether, except a space left for ventilation. A thick covering of matting or straw will preserve them from the cold of winter, or from what is even more dangerous, the treacherous gleams of a winter's sun, which often induce the bees to leave the hive, and then they die from cold before they can return. If the hive has been already protected by a layer of Roman cement on the exterior, hardly any other protection is requisite. Roman cement will render a straw hive as durable as a wooden one, make it water tight, and effectually keep out mice and other vermi who are particularly given to burrowing in the straw, ay 
devouring the honey. The cement has also the advantage of being' cheap, and greatly assists in fixing. windows and other appliances. The coating should be tolerably thick, and then not even the insidious moth can obtain an entrance except through the door, where the bees will keep a good watch, and the hive will lose less heat in winter, and gain less in summer than can be managed even by the most careful dressing and undressing the hive with straw bandag'es. If the hive is as it should be, placed in a shed, the bees may be considered as quite secure from cold.

If the stock does not appear strong enough, another should be added to it, and the conjoint stocks will not require an ounce more honey than the original inhabitants. One foe, not the less dangerous from being unsuspected, is an internal dampness, which gives no outward sign, but has caused the destruction of many a hive of bees, much to the astonishment of the owner, who has probably bestowed great care on them. A very effectual method of preventing this misfortune is to place over the aperture in the top of the hive a bell glass, covered with flannel or cloth, and wiping away the moisture as it appears on the inside of the glass. This precaution is more necessary in a wooden than in a straw live, as the latter partially absorbs the vapour. In all probability bees sustain the severity of a Russian winter better than they do our comparatively mild season, because the air is much more dry than in England.

Several experiments have been tried, some very successfully, many completely the reverse, upon the apparently murderous plan of burying the hives in the winter, only leaving a tube to communicate from the mouth of the hive with the air. In or two cases the bees survived through the whole winter, and only consumed a few ounces of honey, but in many other cases, the experiments were terminated by the death of the bees.

When the spring begins to appear, the hives should be still more carefully shaded from the sun's rays, and if they should begin to swarm about the entrance, a shower from a watering-pot will lead them to believe that it is raining, and that they had better go on with their work within the hive.

Aspect.-A north, north-east, on north-west aspect is 
recommended; but there appears no objection to a direct southern one, if you take care that the fierce rays of the meridian sun shall not stream upon the poor perspiring bees in summer, and if you take care to prevent its perfidious rays in winter from wooing the bees forth in the delusion that, as the old song: says, -

\section{"Summer is ycoming in, Loud sing cuckoo;"}

and then leaving them before they have got back to the hive, chilled and hungry, no flowers to be seen, dropping' down at last in their exhaustion to rise no more.

The hive should always, if possible, be placed so as to be free from the first rays of the morning sun, as the bees are sometimes tempted out too early, and tire themselves before the flowers are fairly opened. More real work appears, from the experience of a well-known entomologist, to be done between eight o'clock A. M. and twelve than in the whole of the day beside. The vicinity of high trees should be avoided, as although they afford shelter from the wind, yet they are apt to prove the destruction of the bees, who are blown among their branches, and beaten down by the twig's. Moreover should a swarm by any accident escape, and settle upon a lofty branch, it will not be a very easy matter to capture it. "Whatever trees are placed near' the hives should be low, and if possible bushy. The bees should be provided with water as near their hives as possible. A very shallow, gravel-bedded brook is best thing they can have; but if this is not attainable, several flat plans filled with water, should be placed near the lives and resting-places formed for the bees by a number of pebbles on which they can sit. A little salt occasionally dissolved in the water will be found advisable. Of course it will be found very useriul to plant near the hive the plants mentioned on p. 75, to which may be added mustard, single roses, sag'e, radishes, parsley, peas, marigolds, parsnips, lily, privet, \&c. The last-mentioned shrub is also an excellent one for shelter to the bees, as the twig's keep themselves in due bounds, and do not whip down the wearied bees in a high wind. Lime-trees are also excellent neighbours, ns the leaves are at certain times of the year covered 
with honey-dew, and the bees frequent them in such numhers, that to pass under an avenue of limes when the honeydew is on them, is like walking amid innumerable swarms of bees unsettled as to their future destination. All evilscented places, such as brick-kilns, tan-yards, or bonecrusher's', should be avoided; and the careful bee-keeper will cautiously shun factories or mills, whether worked by steam or water, as the bees have a peculiar objection to noisy neighbourhoods, and always prefer trees to chimneys. Richardson advises that if your bee-shed or stand is placed against a wall, it will be necessary to ascertain that there is no dunghill against its opposite side, as he found his boxes deserted by the bees, who have a decided objection to a permanent residence in such an unsavoury locality, although they frequently pay visits to dung-heaps, for the purpose of drinking the moisture which drains from them. This may, however, be avoided by placing salt in the supply of water near the hives, as has been described.

\section{COLLATERAL, NADIR, AND SUPER HIVES.}

So far for the simple single hive. We will now describe shortly the compound hives. These are chiefly of three sorts, the Nadir, Collateral, and Super. The Nadir hives are those where the additional hive is placed under the original; the Collateral, those where, as the name implies, the hives are placed side by side. Of these, the Collateral are much to be preferred, as in the Nadir hives the bees are exposed to many inconveniences, among which may be reckoned the labour of mounting up through two hives, to deposit the honey or pollen which they have brought home, a task which to an already wearied and heavily laden bee would be an addition to its labours. Moreover, the brood combs are apt to be distributed unequally, so that the bee-master is never sure of getting a hive full of pure honeycomb, as he can in the collateral hiving. Super-hiving is where the additional hive or box is placed above the mother hive. To this nearly the same objections apply as to the nadir system, and I shall, therefore, merely describe the collateral system. 'This may be accomplished either with straw hives or wooden boxes. Straw hives, however, are not very manageable, or at 
least do not answer for the centre box, and the description will, therefore, be only of boxes. It is not to be expected that every one will be able to purchase the somewhat expensive series of hives described by Mr. Nutt, but it is hoped that his description of a "set" of collateral hives will be sufficiently clear to enable any man of tolerable ingenuity, and moderately acquainted with the use of tools, to construct a set for himself, even though he be no joiner or carpenter. $\mathrm{He}$ need not expend his time upon the external ornament of the hives, or make quite as elegant a set as depicted by $\mathrm{Mr}$. Nutt, but if he only takes care to have the interiorsmooth, and carefully worked, using well-seasoned wood, against which the rays of the meridian sun, the drenching summer showers, or the frosts of the winter months, may beat in vain, his hives will answer as well if not better than many an elegant and carefully finished bee-palace such as. are firequently reared.

Mr. Nutt's description of the proper form and materials of the collateral boxes is as follows:-

"The best wood for them is, by some, said to be red cedar; the chief grounds of preference of which wood are, its effects in keeping moths out of the boxes, and its being a bad conductor of heat. But of whatever kind of wood beeboxes are made, it should be well seasoned, perfectly sound, and free from what carpenters term shakes. Good, sound, red deal, answers the purpose very well, and is the sort of wood of which most of my boxes have been made hitherto. The sides of the boxes, particularly the front side, should be, at the least, an inch and a half in thickness; for the ends, top, and back parts, good deal, one inch thick, is sufficiently substantial; the ends that form the interior divisions and openings must be of half-inch stuffs, well dressed off, so that, when the boxes and dividing tins are closed-that is, when they are all placed together-the two adjoining ends should not exceed five eighths of an inch in thickness. These communication-ends, the bars of which should be exactly parallel with each other, form a communication or division as the case may require, which is very important to the bee, and by which the said boxes can be immediately divided withouic injuring any part of the combs, or deluging the bees with liruid honey, which so fiequently annoys them, in extractine 
their sweets from the piled or storified boxes. This is no: the only advantage my boxes possess; the receptacles or fiame-work, for the ventilators, must be four inches square, with a perforated flat tin, of nearly the same size; and in the middle of that tin must be a round hole, to correspond with the hole through the top of the box, in the centre of the frame-work just mentioned, an inch in diameter, to admit a perforated cylinder tin rentilator, nine inchess long. This that tin must liave a smooth piece of wood, well made to fit it closely, and to cover the firame-work just mentioned, so as to carry the wet off; then placing this cover over the square perforated tin, your box will be secure from the action of wind and rain. The perforated cylinder serves both for a ventilator, and also for a secure and convenient receptacle for a thermometer, at any time when it is necessary to ascertain the temperature of the box into which the cylinder is inverted. Within this frame-work, and so that the perforated flat tin described may completely cover them, at each corner make a hole with a three-eighths centre-bit through the top of the box. These four small holes materially assist the ventilation, and are, in fact, an essential part of it.

"We next come to the long floor, on which the three square bee-boxes which constitute a set stand collaterally. This floor is the strong top of a long, shallow box, made for the express purpose of supporting the three bee-boxes, and must, of course, be superficially of such dimensions as those boxes, when placed collaterally, require; or if the bee-boxes project the eighth part of an inch over the ends and back of this floor box, so much the better, because in that case the rain or wet that may at any time fall upon them, will drain off completely. For ornament, as well as for use, this Hoor is made to project about two inches in front; but this frojection must be sloped, or made an inclined plane, so as to carry off the wet fiom the front of the bozes. To the centre of this projecting front, and on a plane with the edgee of the part cut away for the entrance of the bees into the pavilion, is attached the alighting loard, which consist of a piece of planed board, six inches by three, having the two ontward corners rounded off a little. The passage from this alighting board into the pavilion is cut, not out of the edge 
of the box, but out of the floor board, and should not be less than four inches in lengith, and abour half an inch in depth, so as to make a clear half-inch way under the edge of the box for the bee-passage. I recommend this as preferable to \& cut in the edge of the box, because, being upon an inclined plane, if at any time the wet should be driven into the jlavilion by a stormy wind, it would soon drain out, and the iloor become dry; whereas, if the entrance passage be cut out of the box, the rain that may, and at times will, be lirifted in, will be kept in, and the floor be wet for days, and jerliaps for weeks, and be very detrimental to the bees. In klepth the floor-box, measured from outside to outside, should be four inches, so that, if made of three-fourth inch deal, there may be left for the depth of the box part two inches and a half. Internally it is divided into three equal compartments, being one for each bee-box. Admission to these compartments, or under-boxes, is by the klrawer, or drawer fronts, or blocks, which will be described presently.

"The bottom or open edge of each of these boxes, should be well planed; and made so even and square, that they will sit closely and firmly on the aforesaid Hoor, and be as air-tight as a good workman can make them, or technically expressed, be a dead fit all round. In the floor board are made three small opening's, $i$. e., one near the back of each box. These openings are of a semilunar shape (though any other shape would do as well), the straight side of which should not exceed three inches in length, and will be most convenient if made parallel with the back edge of the box, and about an inch from it. They are covered by perforated or by close tin slides, as the circumstances of the apiary may require. The drawer, the front of which appears under the middle box, is of great importance, because it affords one of the greatest accommodations to the bees in the boxes. In this drawer is placed, if necessity requires it, a tin made to fit it, and in that tin another thin frame, covered with book muslin, or other fine strainer, which thoats on the liquid cleposited for the sustenance of the bees. Here, then, you liave a feeder containing the prepared sweets in the immesliate vicinity of the mother hive, and without admitting the coid or the robbers to annoy the bees. When you close the 
drawer, thus prepared with bee food, you must draw out the tin placed over the semilunar aperture, which will open to the bees a way to their food in the drawer beneath. The heat of the hive follows the bees into the feeding apartment, which soon becomes the temperature of their native hive."

'The advantag'es of this plan are evident-the ventilating' principle being the key to its management. The queen-bee will invariably deposit her eg'gs in the hottest part of the hive. This will be the central box, or " pavilion of nature," as it is called, in which the sovereign of the hive resides, and which is suffered to become as hot as the bees choose to render it, as when the heat becomes too unbearable, they can, as has been before mentioned, ventilate their home with perfect success. Here, then, in the centre box, are the brood combs. To the two side-boxes are affixed ventilators which keep them cool, whether the bees approve of it or not, and in consequence, the queen does not choose to deposit her eg'gs in such a cold atmosphere, where they would run a chance of perishing for want of that heat which the ventilators render impracticable. In the side-boxes, therefore, will be found the honey and pure wax uncontaminated by the presence of innumerable grubs, which in the old single straw hive smotheration system, used to be broken up together with the honey combs, and contribute the contents of their semi-liquid persons to the mass of honey collected in the pan below them. The apiarian should always have at least one spare box to substitute in the place of the one taken away.

The apiarian has by these means the most complete command over his bees. He can force a swarm before its time, or extend it, just as he pleases; he can fill his boxes with honey or with brood, as he thinks may prove more adrantageous; and all this without harassing the bees by too officious meddling.

Lest, however, the young bee-master should be too sanguine about the success of his collateral sets, it must be mentioned that this system has not always proved so efficacious as Mr. Nutt found it. These failures have probably arisen from too close an adherence to the letter of the directions, withont taking into consideration other causes whicks 
called for some change in the details. For instance, a considerable amount of heat is required for building combs. "T'le external temperature may be sufficient during the hot days for this purpose, but in this very changeable climate, a succession of cold days is very likely indeed to take p!ace. If, therefore, the bee-master suffers as much of the external air to pass into the hive on the cold days as on the hot, of course the temperature will be too low, and he will find no combs made. With regard to the occasional occurrence of brood in the side-boxes, notwithstanding careful ventilation, MIr. Westwood thinks that probably a swarm, instead of leaving the hive with the queen, has taken possession of the side-box, which doubtless appeared to them to be a very pleasant place, without the trouble of searching. He also supposes that two or more swarms of bees can make use of the same entrance without quarrelling, and supports this view by the instance of those large colonies of bees which take undisturbed possession of roofs of houses, \&c., and which increase to a very g'reat extent.

\section{UNICOMB AND LEAF HIVES.}

The above-mentioned hives are intended to procure for the bee-master as much honey and as many bees as possible, but are of comparatively little use in the hands of one whose chief object in keeping bees is to observe the habits and proceedings of these interesting insects. For this purpose it is necessary to have a hive which shall be so flat as not to permit the bees, by crowding together, to hide the proceeding's of the queen, or to hinder their own habits from being. observed; and at the same time to give room for the bees, and a firm hold for their combs. The greater part of the hive must also be made of some transparent substance, such as glass, or, as some prefer, talc. The usual form now employed, is a modification of that invented and used by Huber, who is said to have obtained the first idea of a flat hive from the Candiotes. By joining together several of these hives, he also procured plenty of honey in addition to the opportunities which they afforded of inspecting the habits of the bees.

'The hive, or rather hox, is oblong, the height about eighteen 
inches, the width two feet, and the distance between the donss about an inch and a half, or two inches. These doors are of glass, and form the two sides of the hive. In order to give the combs a firm foundation, the hive should be divided into two parts-some recommend four-by a slight bar, to which the bees can hang the combs, and which serve to divide the weight, as a comb of the full size of the hive is apt to fall from its attachment if the weather be hot. This arrangement only permits of one layer of comb, which is just wide enough to permit the bees to pass between the opening of the cells and the glass-door, so that the bees cannot cluster in sufficient number's to hide themselves or their queen, and the observer can watch the proceeding's on each side of the comb. Some hives are made to turn on a pivot in order to bring them more conveniently before the eye, but this precantion is very unnecessary. Of course the hive thas an entrance at each side, so that the observer closes that nearest to him, and opens the other every time that he chang'es his position. The glass-doors must be covered with two very thick wooden shutters, not less than an inch and a half in thickness, partly because the bees dislike the light, and should never be exposed to it except when they are being' examined, and partly in order to defend them from the cold, to which they are very sensitive. A very excellent addition may be made to a leaf hive, by placing them upon a small box with very thick sides, in which they may cluster during. the winter, as many hives have perished because the leaves are so close as to prevent clustering altogether. Each observer will be sure to make his own additions and improvements, so that nothing more need be said on the subject. Perhaps the doors may be improved by being made of four, six, or eight small panes of glass, each of which is removable without disturbing the others, that if any one comb is wanted, or any bees are to be abstracted, the hive may not be thrown into such confusion as the opening of an entire side always must occasion.

The Best Hive-is that one which, while it best secures the health and prosperity of the inmates, bes facilitates the particular modes of operation adopted by the owner; these admit of great variety, especially with regard to the taking of honey, and the increase of the number of communities. 
We know of no hive more generally useful than Mr. Grant's, the one here shown, and which we venture to copy, with a few alterations, from the Gardener's Chronicle. At all events, a brief description of this will show the kind of thing desiderated, and afford a good point of departure for tbose who can improve upon it.

Fig. 14.

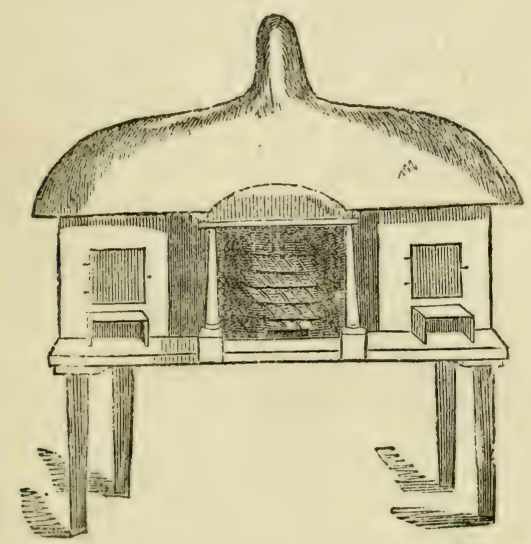

The straw live is seen in the centre, with its entrance at the bottom, and a projecting foot-board, or landing-place, nnder cover of the portico, so that when the bees hurry home in numbers on the approach of rain (and bees are the best of harometers), they may not be drenched while waiting for room to enter. "The square compartments at the sides are moveable boxes, about ten inches square, and one inch thick, with a shutter enclosing a glass-window to each. These would have been better placed at the back, so that the observer might have been out of the way of the bees as they made their entrances and exits. Perhaps, too, it would be better to treat these side-boxes as mere cases for hives to be put within them; as it is a great advantage to have all hives exactly of the same size and shape. No division need in that case exist between the different compartments of the case beyond the walls of the hive themselves. Each box has its own separate entrance and footboard. Bell-glasses for 
'ceeiving honey may be placed on the hive, and on the side. boxes. A moveable roof, light and warm, cover's the whole, and is put on and off without difficulty. A tube of communication, which can be opened or closed at pleasure from the outside (and which does not prevent the removal of a sille-box), extends from the straw hive in the centre to each of the boxes, so that the bees can pass freely, when the owner chooses to let them. The view of the hive given in the cut is nearly the same as that of Mr. Grant's, the principal alteration being that each of the side entrances are furnished with perches to shelter the bees while waiting for ardmittance. If it could be done, a single leg in the centre of the hive is preferable to the four leg's at the angles, as rats and mice might then strugghle in vain to g'et at the honey

\section{WAX, HONEY, \&c.}

As the bees yield up the produce of their labours with difficulty, and require the reason of man to be set against their instinct, so are they anxious to regain that property of which they have been deprived. Their sense of smell is so keen that they can discover their stolen property at an almost incredible distance, and have been known completely to empty some combs which had been inadvertently left exposed. When the combs have been placed in the room where they are to be strained, it is strongly recommended to burn rotten hay, or something of that description, at the windows, in order to drive away the bees who will in all probability be hovering about.

A pair of forceps, such as watchmakers use, will be found very useful in removing the stray grubs or other matter's which are very likely to get mixed with the combs. When these substances are entirely removed, the combs should be broken into small pieces and placed on a strainer, through which the honey passes into a vessel beneath, and is nearly equal to that of the bell glasses. When no more honey will run of its own accord, the comb should be squeezed in a clean cloth, when a large quantity of second-rate honey will be procured. The honey must be carefully kept from the air, and if clarified will be better. This operation is per- 
formed by placing the jar of honey in hot water, and skimming it carefully.

The wax, after the honey has been separated, should be placed in rain water, heated over a moderate fire, and continually stirred. It should then be strained through canvas (which requires rather powerful pressure-that of a lever is the easiest), re-melted, and run into moulds. It will then have a yellow tint, but may be bleached by melting it, and running it into very thin flakes, which must be placed in the sun. After repeating this several times, the wax will become perfectly white. It should, when poured into the moulds, be suffered to cool very slowly, 0 i it will be full of cracks.

For directions respecting the drink of the heroes of old, who considered the height of felicity to consist in sitting in the hunting grounds drinking mead out of the skulls of their enemies, the reader is referred to various books of cookery, where full directions may be found among those treating of home-rnade wines, among which, in our opinion, it fully deserves to be placed, and may fairly be ranked with sage-tea and many other atrocious compounds.

The Situation-must be dry and airy unough fierce winds must be completely shut out by the natural defences of the place. The hive must be protected by an overhanging' canovy against rain and drip. Damp is, perhaps, 4. greatest of all bee-enemies. As to the others, let your hive stand upon one or more posts or pillars, according to its size (most securely fixed, accidents with hives are very dangerous things), so that "mice and rats, and such small deer," may not be able to annoy the bees. Some effectual precautions should be taken to prevent children from interfering in any way with the bees, either intentionally, or, which is more likely, by accident. There are cases on record of children suffering severely by some unlucky interference, construed no doubt by the bees into an attack, and resented accordingly.

Beside the legitimate enemies of bees, above mentioned, there are such things as bee-robbers, \&c., men who make a business of robbing' every hive that they can move. Their depredations are committed by night, and, armed with a full bee-dress, they quietly empty the hives without re 
quiring the use of a lantern or smoke. But a grood wooden live, firmly screwed to its foot-board, and that firmly attached to its supporting post, will generally baffle the efforts of the skulking bee-robber. If the hives are placed in a shed, as should always be the case if it is possible, the roof should not be thatched, as the straw affords a restingplace for marauding rats and mice. With regard to the children's misdemeanours, the writer of these lines, when a boy of eight or nine year's' old, went to see a newlyestablished bee-garden near Oxford, and after wandering among the hives for some time with perfect impunity, began examining their structure. Being greatly scandalized at not being able to see the proceeding's of the bees through their entrance-hole, he blew violently in at the door, and then applied his eye to the aperture. The consequences to him were not unlike those recorded of the philosophical monkey, who put his head into the mouth of a loaded cannon while he applied a match to the touch-hole. At all events the results of the experiment, although not quite so violent, were certainly felt for a longer period.

Ventilation.-Do not attempt to teach bees the art of ventilation. We have seen that they know how to do what we do not-keep the air as sweet within their home as it is without. Open any crevice in the hive, and they will immeditely stop it up with propolis. Your experiments may worry, but will never teach or improve them. We do not here speak of ventilating any side-hives for special purposes, but of the chief one, where the bees live and are rearing their brood. Mr. Grant once tried an experiment in the way of making the bees niore comfortable, by simply covering the ordinary entrance at the commencement of frost with a piece of perforated zinc; "but in a few minutes afterwards the bees became unsettled, and crowded to the entrance, evidently oppressed by the alteration I had made, and appearing to absorb the condensed air on the zinc, which induced me to remove it altogether. Shortly afterwards I attempted to contract the entrance by inserting a piece of wood one inch long by half-an-inch thick, leaving. about one and a half-inch open. The wood had not been applied many minutes, when two of the bees came and examined it, with the object of removing it, as they fixed 
their hind-legss to it, and pulled with all their strength; but failing in their endeavours, they, with several others which subsequently joined them, ran about the entrance, and appeared to be very uneasy. As I could not bear to seo them uncomfortable, I withdrew the piece of wood, upon which two of them immediately occupied the position where it had been placed, and continued fanning for nearly ten minutes as if it had been the warmest day in June." He then left them to ventilate themselves ever after, with the most perfect success. And here let us observe, that $\mathrm{Mr}$. Grant has shown that zinc should never be used in hives; a white powder forms upon it, which is presumed to be poisonous, and which the bees evidently made great exertions to be rid of.

\section{HONEY TAKING AND SWARMING.}

Together with the spring come the chief duties of the apiarian. The object of his labours will now be two-fold. Firstly, to secure as much honey as he can without detriment to the bees, and secondly, to increase the number of his swarms, in order to give him a larger stock against next year's labours. But if he takes honey he will check the increase of the swarms, and if he multiplies his swarms, it will be at the expense of much present honey, for the sake of more hereafter. He will therefore balance the question of profit in his mind, and encourag'e either one or the other, for from the same hive he cannot expect much of both. Bees, like men, desire to increase and multiply, and in consequence all their preparations and filling of their numerous storehouses is with reference solely to that view, after they have collected sufficient nourishment to supply their own necessities, and not with any dsinterested view of affording their master a rich harvest. This object chey can generally attain, and can furnish amply sufficient stores of food to supply the coming generation, no matter how numerous the fecundity of the queen-mother may cause that generation to be. But it is clearly impossible th it they can rear the greatest possible amount of brood, and at the same time afford to man the greatest possible weight of honey, which honey was only intended for that brood, and cannot support both the brood 
and the bee-master. The judicious apiarian must, therefore, constantly distinguish between these two departments of bee-management, and either promote the one in which he most desires to be successful, or strive to hit that golden mean which shall preserve a moderate increase both of boney and brood.

We will now suppose that the apiarian has followed the instructions given respecting the caps to be placed upon hives, and has diligently capped his hives, by always keeping a store of fresh glasses by him, and immediately replacing the filled cap with an empty one charged temptingly with a piece of pure white comb. He will in that case have obtained nearly two pounds per diem of the very purest honey, which if sold, will at this comparatively early season of the year, always fetch a very high price, for the appearance of a glass-cap filled with honeycomb is so elegant as always to secure a sale for it, as an ornament to the breakfast table. If later in the year, say in July or August, the hive is strong enough to bear a further deprivation, the bee-keeper should fumigate the bees, and then cut out some of the combs. Of course this is only to be done if the hive is a single one, as if it is a double or treble hive, the combs can be removed almost without the knowledge of the bees. The best method of fumigating is as follows :-

\section{FUMIGATION.}

Fumigation implies directing certain smoke of a stupifying: character into the hives, so as to render the bees harmless while their combs are being removed, while at the same time no injury is done to the bees themselves. There are several substances which stupify; tobacco is one, but it is apt to give the wax and honey an unpleasant flavour, and we will, therefore, say nothing about it. The best material that can be used for this purpose, is the lycoperdon, or common puff-ball, which is also known among the peasantry of the various parts of England, by the names of frog-cheese, mully-puff, and punk-fist. A fine specimen of this fungus will grow as large as a child's head It may be found in 
almost any field where mushrooms grow, but if none grows near the operator, it may be cheaply procured, ready dried and prepared, at the herbalists' in Covent Garden, and other places. It should always be gathered when nearly ripe in dry weather, and either exposed to the heat of the sun or placed in an oven until it turns brown and leathery. Some always squeeze it flat during the drying process, as it then can be packed easier, and appears to take fire sooner than if left to dry in any shape it chooses to take. In order to insure its burning freely when lighted, some recommend that when dried, it should be dipped in a very weak solution of saltpetre, and again dried. There are many ways of applying the smoke, but all are useless unless the fungus is retained outside the hive, and only the smoke permitted to enter, as the bees are sure to fall on the burning mass, and thus many will be killed or maimed. Moreover, the operator ought to be able to regulate the amount of smoke poured into the hive. Mr. Cotton, the author of "My Bee-Book," managed it by having a tin box made to fit the nose of a pair of bellows, in which was placed a piece of lighted fung'us about twice the size of a hen's eg'g. There were two opening's in the box, one to admit the nose of the bellows, and the other immediately opposite, from which the smoke poured. The box being fixed on the nose of the bellows, and the end being placed against the entrance of the hive, a few vigorous puffs soon fill the hive with the stupifying smoke, under whose effects, after a brief buzz of indignant astonishment, the bees are heard falling as thick as hail, and in a few minutes, all is still within.

In performing the work of fumigation, many failures have occurred, from setting about the operation too hastily, or from the non-observance of a few rules that can be easily remembered, and as easily put in practice. In the first place, great care must be taken that the smoke of the fungus or other material used for the purpose is not admitted into the hive at too high a temperature. If this is the case, the heat of the smoke will in the first place scorch and kill the bees who will rush to the entrance of the hive on the first intrusion of the fumigating tube, and will also melt the wax of the combs, and do considerable inischief. The tube, therefore, should be a very long one, and small in 
diameter. There is no hurry about the operation, work the bellows quite deliberately, and the danger of burning the poor bees, or spoiling the combs will be avoided. There is hardly a more pitiable sight than to find on turning up the hive a number of bees lying on the board, with scorched and shrivelled wings-a loss of no small importance, as you will want every bee to set to work immediately, to repair the devastations committed in the hive. Another mistake not unfrequently occurs in following. Mr. Cotton's directions too literally. It is not sufficient to have the fumigating box merely made of tin, as will most certainly be done if that order is sent to a tinman, for the heat of the ignited puffball will speedily melt the solder, and the whole apparatus will fall to pieces. A case of this kind occurred very recently. The box and tube were made according to order, the clay prepared for stopping the entrance of the hive round the tube, the fungus was duly lighted, placed in the box, the bellows fitted, and then vigorously worked. Suddenly while the operators were complacently puffing away at the bellows, and congratulating themselves on securing both honey and bees by this method, the box fell in pieces, the tube, consequently, was drawn out of the hive door, and out rushed the bees in a tumultuous state of indignation, thereby putting their would-be captors to an ignominious flight. So lest you meet with a similar misfortune, give particular orders to have the whole affair made fire-proof, and then you may proceed without the least danger. Of course this must all be done some hours after dark, or the bees, who are already out, will soon signify their dislike of finding intruder's when they return to the hive. It is also necessary to be very quick in cutting out the combs, as the bees do not remain long in their state of torpor or intoxication, and are quite ready on their revival, to employ their stings. Always examine the combs that are removed, to see if any bees are left in them, as not unfrequently, when they begin to find that they cannot overpower the vapour, they dive to the bottom of an empty cell, and sometimes are so protected by this precaution, that they revive rather sooner than their less fortunate companions. The wax of the combs thus obtained is much whiter than if sulphur is used, and, of course, will fetch a higher price in the market, 
besides being free from a slight tinge of sulphury flavour, which hangs about them for a long time.

For fumigating, the circular bellows, set in motion by a winch, are much superior to the double bellows, as a constant steam of smoke is introduced into the hive, instead of a series of puffs. Mr. Pettigrew recommends (probably because they can be more certainly obtained when wanted), cotton rags, tightly rolled up in the form of a candle, and applied in the same way as the fungus. If so, it will be found advisable to steep the rags in a solution of nitre, as otherwise they are very apt to gro out before a sufficiency of smoke has issued from them. The solution, however, must be weak also, or it may do mischief instead of good, for ignited nitre is apt to send forth sparks, especially if it is urged on by a draught of air. It may be possible that ether or chloroform may answer better than either fungus or rags, but the experiments do not yet appear to have been sufficiently numerous to enable one to speak with confidence. At all events, although chloroform and ether may not supersede fungus and nitre in stupifying bees, the smoke of puffball threatens to supersede chloroform and ether in their anæsthetic power as applied to human beings. We are bound to observe that fumigation may not be altogether so harmless as is supposed, and therefore should not be used without necessity.

When, after carefully applying the fumigating apparatus, as has been described above, the stillness that reigns in the hive indicates that the bees are in a state of insensibility, the hive may then be turned up for any necessary operations. If honey is wanted, choose the side combs, so as not to interfere with the brood in the centre, and be moderate. Replace the violated hive carefully, and the bees will soon recover from their state of partial intoxication, and set to work to repair the ravages that have been made in their stores. Nor does fumigation injure the working power of the bees. Unlike the effects of alcoholic compounds, which when taken in an over dose, entirely prostrate the sufferer for some time, the smoke of the fung'ns causes a very transient intoxication, which in a few minutes passes away, and the bees appear rather refreshed than otherwise, after their involuntary debauch. 
DRIVING.

In the hands of a skilful operator, driving will be often found useful, as it partly supersedes the necessity of fumigation. By driving, the bee-master induces his winged auxiliaries to change their position, by working on their fears instead of stupifying what brains they have. The best method of driving the bees will be found in the pages of Bevan, who appears to think very lighly of the operation. "Towards the dusk of the evening, when the family will be all, or nearly all at home, and no annoyance be experienced from stranger-bees, let the hive, or box, be raised gently from its floor-board, and supported on three thin wedges; let an assistant be at hand, provided with a tobacco pipe, or the fumigating box and bellows, from one of which at the moment of raising the hive, let a few whiffs of tobacco smoke be blown into it all round, and a few more after it has been raised. This expedient will soon induce the bees to ascend and congregate at the upper part of the hive. It is next to be inverted steadily on a small tub or peck measure, puffed again, and then quickly and accurately surmounted by an empty hive or box, as nearly of its own diameter as possible. After securely closing the two hives, by tying' a cloth firmly round them above and below the junction, so that not a bee may escape, it will be proper to place an empty decoy hive upon the stand where the full hive stood, to amuse any straggling bees that may have stayed out late, or that may escape during the operation. The conjoined hives are then to be removed into a darkened room, in the manner already described, when, if the hive be well peopled, and the weather warm, by drumming at first gently, and then smartly with the open hands or a couple of sticks on the outside of the hive, the bees will be so alarmed, that in a few minutes they will have ascended into the super. The ascent may always be ascertained by the humming noise attending it. The impulse thus communicated to the bees should be given in the direction of the combs, and by no means upon those parts of the hive which are opposite to their sides, as it might separate them from their attachments. 
"The exchange of habitation having been effected, the nlterior proceedings must be regulated by the object in view. If it be wished to have possession of the full hive, it will be simply necessary to leave the decoy-hive in its place, and after covering the honey combs with a cloth to prevent them from being scented, to carry the bees with their tem porary abode towards their usual place of entrance, when by spreading a cloth on the ground, or on a table, all the bees may be dislodged and made to fall upon it, by a smart stroke with the hands upon the top of the hive, and if one side of the cloth be raised to the resting board, the bees will gradually ascend, and re-occupy their original station."

Driving is made use of by the Persian villagers, whose hives are made in a cylindrical form, and built horizontally into the walls of their houses, the bees' entrance being outside the wall, and a moveable door inside, the end of the hive projecting more than a foot into the room. When the villager wishes for some honey, he drums smartly upon the end of the hive which projects into his room, which causes the bees to withdraw to the other. The circular lid is then quickly opened, as many combs as he wishes for cut out, and the lid closed again.

No one should be without spare hives or boxes ready to be used when required, even if they do not at the outset fit up a complete apparatus. Thus,

1. A spare box or hive will be ready to receive a swarm obtained in the ordinary manner, with all its picturesque but inconvenient accessories: as long watching to know the moment of swarming; long runnings, perhaps, to overtake the vagrant young colony, over hill and valley, brake and brier, and amid interminable ear-splitting tumult, which the bees have the bad taste, it is supposed, to like; and the race often ending in seeing the whole cluster safely deposited in a neighbour's apiary, who swears it went from his hive. If you wish to avoid all that kind of thing, do your best to give the bees no motive for such wanderings, and every conceivable reason to stay where they are. Put a decoy-hive ready, with a delicious piece of comb in it (an old hive, with its own combs, will be still more attractive), and it is most likely the scouts sent out to explore will return 
with such a glowing account of the land of milk and honey they have discovered, that the swarm will be impatient to be off and take possession. This must, however, be done with great care, and the decoy-hive not placed in the air tor. soon, as its seductive stores will not only attract the bees who are intended to be its legitimate occupants, but also wasps, hornets, and robber-bees of all descriptions, so that the swarm will have to inaugurate their entrance by a battle.

Bees always will settle themselves as soon as possible after swarming, and if they have not already determinea upon a new habitation will fix themselves in the first place that they think will suit them. There are many instances known of bees having swarmed unexpectedly, and after escaping from their former owners, having made their habitation in a hollow tree in a wood, or in the roof of some deserted hovel. There have been several instances of bees choosing to make their nests in the roof or tower of a church, and an instance came very recently under the writer's notice. For several years the congregation had been considerably annoyed by the presence of bees during the service, but liad made no particular endeavours to rid themselves of the plague. One summer, however, brought with it such an increase of bees that it was deemed necessary to institute an inquiry; for the winged intruders came in such numbers, and buzzed about so loudly, and frightened the juvenile portion of the congregation to such a degree, that the service could not proceed with any comfort. After some search a hole was discovered in the roof of the church, through which the bees were constantly passing. This was accordingly stopped up, and the workmen retired congratulating themselves on getting rid of their winged enemies so easily. They were, however, quite mistaken, for the bees descended in undiminished numbers. The roof was again examined, and found to be in such bad repair, that the colony of bees who had taken up their residence between the roof and the leads, had found numerous openings, which they had enlarged for their own purposes. How to eject this formidable band was now the subject of deep consultation. Sulphur-smoke would not answer, because it would soon pass out through the apertures in the roof, and besides, there was a very prevalent alarm lest 
the church should be set on fire. At last a veteran apiarian was sent for from the next village. He immediately planted a ladder against the exterior wall, and examined the stones until he discovered the entrance to the bees' habitation. It was a mere fissure between two stones, where some of the mortar had fallen out, and the remainder been extracted by the bees for their own convenience. After surveying the prospect for some time, he declared that a stone must be taken out of the wall before the bees could be dislodged, and immediately began to loosen the stone which had already been partly deprived of its mortar. The bees, of course, were highly indignant at such an assault, but the man coolly proceeded with his work, not heeding their anger in the least. When the stone had been completely loosened, he laid by the crowbar, and deliberately pulled it out with his hands. Out rushed a perfect cloud of bees full in his face; but he quietly laid the stone down, and contented himself with brushing them off his face until he had made further investigations. All the spectators took to flight at the first appearance of the enraged bees; but their imperturbable enemy remained quietly at his post, and after descending the ladder pulled some eight or ten bees out of his hair, and remarked that they had not stung him so much as he expected. It turned out that the man was almost invulnerable to stings; and although several dozen stings or so were in his face they did not leave the slightest mark, and certainly did not appear to inconvenience him in the very smallest degree. He afterwards in the same cool manner extracted the greater part of the combs, and the bees taking the hint speedily evacuated the premises. There was but little honey, but abundance of black, worn-out combs, and plenty of young bees in every stage of advancement. It is said that if any one is repeatedly stung by scorpions the pain diminishes each time, and that at last the system is entirely uninjured by it. An English naturalist was bold enoug to try the experiment upon himself, and found that after he had been stung four or five times the pain was comparatively trifling. Perhaps the same may be the case with regard to the beestings, and the old man just mentioned possibly owed his immunity to his frequent experience, as Mithridates was 
said to have completely fortified himself against poisons, by gradually imbuing his system with them.

3. Adopting as a rule the non-disturbance in any serious way of your stock-hive, so that honey and brood sha there at least flourish together, when you think it is fill (a solid sound from the hive, and a great long-c ntinu d buzz from the bees in answer to a tap, is good evidence of that state) attach your side-box, open the communication, and make the bees enter and leave by the entrance to the side-box, which you will do by closing up the entrance to the other at night when the bees are all at home. A little piece of comb, fastened at the top of the side-box, may b at once a useful hint and a temptation to the bees. This box is to be kept solely for honey-combs by ventilation, which prevents the queen from laying' eg'g's in it. When the heat in the side-box is $70^{\circ}$, you should admit air through the top by means of a piece of tin pierced with holes. A draught through the hive, from the entrance to the roof, now takes place. This must not be done until you see the bees have fairly passed the Rubicon, and have done and ventured too much to be inclined to retreat to the stockhive. When the box is full you can take it away, and replace it emptied, or by another, or by opening a communication to a similar side-box on the opposite side, as in $\mathrm{Mr}$. Grant's hive. The bees in it will soon flock to the queen in the parent hive. This arrangement prevents swarming; or at least has a great tendency to prevent it; as the bees have more room given to them just when they want it. It also raises the stock itself to the highest state of prosperity, as only the surplus honey is taken away, and the brood is not interfered with.

4. But if you wish to have an increase of stock without the inconvenience of natural swarming, you may easily do so by treating the side-box exactly the same as the chief one, that is, by leaving it unventilated. Brood, as well as honey, will then be deposited in it, and you have only to watch for a favourable opportunity of securing two stocks. This should be a little before the natural period of swarming, of which the signs are, clustering on the outside, acrivity and commotion among the drones, inactivity of the workers, portentous silence in the hive in the day (during 
which the prudent bees are supposed to be filling their pockets with provisions for their journey), and a singular humming noise at night, presumed to come from the young queen-bees 'announcing' their advent. But these warning's apply less to the first than to the subsequent swarms. However, there is a pretty good rule for effective action. As soon as you find the side-box is nearly full, watch for an opportunity when the queen, with about twothirds of the bees of the colony, is in the side-box, then cut off the communication with, and remove the parent hive three or four feet distance, and put an empty hive in its exact position. The returning bees will flock into the sidebox as before, and that hive is done with. As to the parent-hive, the nurse-bees will take every care of the brood in it; in fact, they will be just as though a swarm with the queen had left them; and will proceed with due equanimity to supply her place in the approved way. This is the mode practised with success by $\mathrm{Mr}$. Grant, and may be varied according to circumstances. For instance, if the queen should not have been left in the side-box with the greater portion of the bees, and has, therefore, been removed with the parent hive, the rest must be in effect the same, as regards the two hives; most of the bees then might leave the side-box and flock to the queen in the parent-hive; but if there be brood in the side-box, it appear's that the nurse-bees will not desert it, and, therefore, there are still two cornmunities, and both well provided with all they require for a new start in life.

5 . There is also practised, it is said with great profit, a more summary way of proceeding to make an artificial swarm, which consists in fumigating the bees, in order to divide them into two bodies as before. The period chosen is from the beginning of May to the middle of July, and when there are as many bees on the board at the bottom as will fill a thirty-two (eight and a half inches by six) sized flower-pot. 'T'o ascertain this, blow a little smoke into them and turn up' the hive. Before commencing operations, place the hive intended for the new colony on the stand, with a bit of comb in its roof, and a stick across the middle to aid in the support of the combs. If you are short of hives, this one may be used instead of an additional empty hive in per- 
forming the operations about to be described. But the bit of comb may be somewhat in the way. The bees having been stupified by the fumigation, the hive is turned up, its top rested on the ground, and an empty hive placed over it of exactly the same shape (at the edg'es at least), and a cioth tied round the circle of junction. 'Then tap or' drum gently at the sides of the two hives for about ten minutes, in which time probably about two-thirds of the bees will have ascended into the upper hive. The queen, fortunately for the operation, is generally one of the first either to run away from or to confront the danger (we lnow not which it is) by ascending. If your hive have a glass window, as all should have, you can see when about the right proportion have ascended; if not, you must guess with the aid above given of the knowledge of the ordinary duration of time occupied. Now take off the top hive and reverse it also on the ground, while you make sure the queen is there, throwing, meanwhile, the cloth (that you have removed) over the exposed bottom of the parent hive. If the queen be there (and, as we have shown, p. 36 , she is easily distinguishable) you have only to shake queen and bees into the prepared hive on the board, and restore the parent colony also to the ordinary resting-place, where the bees will soon rear a new queen for it. If the queen be not there, then repeat the process with the prepared hive, and so you will catch her at last. You can then return the first batch of bees that were removed either to the parent hive or to the prepared hive, by simply shaking them into the one which most needs them.

Old hives thus deprived of their queens, and made to rear new ones, involve another important advantage. In twentyone days the entire brood will be reared, no fresh brood having been deposited (through the absence of an old queen), and the young queen not having begun to lay, which they do in about ten days after they leave the cell. Here, then, where the hives are heavy, say forty or more pounds in weight, is an opportunity of removing the bees (by fumigation) into a new hive, and selling the contents of the old one. The honey is thus earlier than usual in the market, and fetches a higher price. Weak sw arms should invariably be joined either to strong ones, or to each other, and as soon 
as possible after swarming. It is only a strong community that can so successfully establish themselves before winter, as to be in no danger from its severity. This junction may be performed by fumigation, and taking away one of the queens. A stock without a queen may by the same means le added to one that is more fortunate: and this applies even to the restoration of a swarm to its own parent hive if there be ample room in it.

We have said nothing of the plan of annually destroying the bees, for it is almost an insult to the readers of Books for the Country to suppose they would approve of so senseless and unprofitable as well as cruel a practice. It is quite true that thus all the honey that is made in a season may be obtained at once, just in the same way that all the golden eggs of the goose in the fable were to be obtainerl at once. And if this wholesale deprivation be desired, it is perfectly obtainable without destroying the bees, by simply fumigating them, and removing them to another hive. And if you don't choose to feed the bees during the winter, let somebody else have them that will. It is possible, in a favourable late season, they may not need any assistance. At all events, let it be the golden maxim of bee-management never to allow a single bee to be injured if you can help it.

\section{BEE-DRESS.}

And now, lastly, as to the chances of the bees injuring you. All apiarians agree that there is no danger worth consideration when the bee-habits and temper are duly understood and respected. Treat them as dangerous creatures, as, for instance, by keeping them too remote from intercourse with human society, and they will soon justify your caution. But then it is you who have created the fierceness they will exhibit. Bees don't like people to come in rude perspirations betwixt the wind and their nobility; and, as before pointed out, they have a particular objection to your breathing upon them. It is well, however, to feel safe, as well as know you ought to consider yourself so, not only for your own sake, but for the greater ease of all your operations. Therefore, wear a bee-dress at all such times, until, at least, experience says you may do without it. Such a 
dress has been already described. Thus attired, the apiarian may perform in entire peace of mind the most delicate operations, and be freed from all danger of becoming the actor in some new scene as interesting and dramatic, but also as alarming and dangerous, as that described by Thorley, which we transcribe for the reader's edification, and with which we ronclude.

"In or about the year 1717, one of my swarms settling among the close-twisted branches of some codling-trees, and not to be got into an hive without more help, my maidservant, hired into the family the Michaelmas before, being in the garden, very officiously offered her assistance, so far as to hold the hive while I dislodged the bees, she being little apprehensive of what followed.

"Having" never been acquainted with bees, and likewise afraid, she put a linen cloth over her head and shoulders, concluding that would be a sufficient guard, and secure her from their swords. A few of the bees fell into the hive; some upon the ground; but the main body of them upon the cloth which covered her upper garments.

"No sooner had I taken the hive out of her hands, but, in a terrible fright and surprise, she cried out the bees were got under the covering, crowding up towards her breast and face, which immediately put her into a trembling posture. When I perceived the veil was of no further service, she at last gave me leave to remove it. This done, a most affecting spectacle presented itself to the view of all the company, filling me with the deepest distress and concern, as I thought myself the unhappy instrument of drawing her into so great and imminent hazard of her life, which now so manifestly lay at stake.

"It is not in my power to tell the confusion and distress of mind I was in, from the awful apprehensions it raised; and her dread and terror in such circumstances may reasonably be supposed to be much more. Every moment she was at the point of retiring with all the bees about her. Vain thought! to escape by flight. She might have left the place indeed, but could not the company, and the remedy would have been much worse than the disease. Had she enraged them, all resistance had been vain, ana nothing less than her life would have atoned for the offence. 
And now to have had that life (in so much jeopardy) insured. what would I not have given!

"To prevent, therefore, a flight which must have veen attended with so fatal a consequence, I spared not to urge ius the arguments I could think of, and use the most affectionate entreaties, begging her, with all the earnestness in my power, to stand her ground, and keep her present posture; in order to which, I gave encouragement to hope, in a little space, for a full discharge from her disagreeable companions; on the other hand, assuring her she had no other chance for her life. I was, through necessity, constantly reasoning with her, or else beseeching and encouraging her.

"I began to search among" them for the queen, now got in a great body upon her breast, about her neck, and up to her chin. I presently saw her, and immediately seized her, taking her from the crowd, with some of the commons in company with her, and put them together into the hive. Here I watched her for some time, and as I did not observe that she came out, I conceived an expectation of seeing the whole body quickly abandon their settlement; but instead of that, I soon observed them, to my greater sorrow and surprise, gathering closer together without the least signal for departing. Upon this I immediately reflected, that either there must be another sovereign, or that the same was returned. I directly commenced a second search, and in a short time, with a most agreeable surprise, found a second or the same; she strove, by entering further into the crowd, to escape me, which I was fully determined against; and apprehending her without any further ceremony, or the least apolog'y, I re-conducted her, with a great number of the populace, into the hive. And now the melancholy scene began to change and give way to one infinitely more agreeable and pleasant.

"The bees, presently missing their queen, began to dislodge and repair to the hive, crowding into it in multitudes, and in the greatest hurry imaginable. And in the space of two or three minutes the maid had not a single bee about her, neither had she so much as one sting; a small number of which would have quickly stopped her breath.

"How inexpressible the pleasure which succeeded her 
past tears! What joy appeared in every countenance upon so signal a deliverance! and what mutual congratulations were heard! I never call to mind the wonderful escape without a secret and very sensible pleasure. I hope never to see such another sight, though I triumph in this most noble stand and glorious victory:" 


\section{Suitable for the Country and Sea-side.}

\section{, By CHARLES LEVER.}

Price 2s. each.

Con Cregan.

Jack Hinton.

Charles O'Malley, 2 vols.

Daltons, 2 vols.

Arthur O'Leary.

Harry Lorrequer.

Knight of Gwynne, 2 vols. The Dodd Family, 2 vols.

O'Donoghue.

Tom Burke, 2 vols.
Davenport Dunn, 2 vols. The Fortunes of Glencore. Roland Cashel, 2 vols. One of Them. The Martins of Cro' Martin, 2 vols.

Sir Jasper Carew. Maurice Tiernay. A Day's Ride. Barrington.

\section{By ALEXANDRE D U MAS.}

\section{Price 2s. each.}

I8o Half Brothers.

I 284 Marguerite de Valois.

Price 2s. 6d. each.

I8I The Count of Monte 285,286 Vicomte de BrageCristo. lonne, Vols. I. and II. I88 Chevalier de Maison Rouge. Is. 6 d.

\section{By ALBERT SMITH.}

Price 2s. each.

II9 Adventures of Mr. Ledbury.

I26 Scattergood Family.

270 Christopher Tadpole.
28I Pottleton Legacy.

I 3 Marchioness of Brinvilliers. Is. $6 d$.

The Medical Student. Is.

\section{By HENRY COCKTON.}

Price 2s. each.

254 Percy Effingham.

27 I Valentine Vox.
408 George Julian. 422 Stanley Thorn. 


\section{A Catalogue of Books}

\section{By MISS WETHERELI.}

\section{Price 2s. each.}

330 The Old Helmet. 367 Melbourne House. 403 Ellen Montgomery's Book-Shelf.
404 The Two School-girls. 43I The Wide, Wide World. 432 Queechy.

\section{By AUTHOR OF "WHITEFRIARS."}

\section{Price 2s. each.}

28 Whitefriars.

53 Whitehall.

67 Cæsar Borgia.
I32 Owen Tudor.

244 City Banker.

306 Mauleverer's Divorce.

\section{By VARIOUS AUTHORS.}

\section{Price 2s. each.}

44 The Night Side of Nature.

50 Susan Hopley.

68 Scottish Chief.

109 Pastor's Fireside.

I55. Prairie Bird.

I57 Petticoat Government.

I58 Captain Blake.

I60 The Bivouac.

I67 Colin Clink.

I68 Hector O'Halloran.

I 70 Country Curate.

I75 The Clockmaker. 2s. $6 \mathrm{~d}$.

I 76 Rory O' More.

I79 Manœuvring Mother.

182 The Two Frigates.

I84 Topsail Sheet Blocks.

190 Soldier of Lyons.

I95 Pirate of the Mediterranean.

197 Mothers and Daughters.

198 Quadroon.

199 War Trail.

2IO Gilbert Gurney.

Mirs. Crowe. Mrs. Crowe. Fane Porter. Fane Porter. Hon. C. A. Murray. Mrs. Trollope. Maxwell. Maxzell. Hooton. Maxwell. G. R. Gleig. Sam Slick.

Samuel Lover. Author of "The Flirt." George Cupples. The Old Sailor. Mrs. Gore. Kingoston. Mrs. Gore. Mayne Reid. Mayne Reid. Theodore Hook. 8 
Suitable for the Country and Sea-side.

By VARIOUS A UTHORS-Continued.

Price 2s. each.

2II A Wife to Order.

214 Trevelyan.

222 Pride of Life.

226 Who is to Have It?

236 Two Convicts.

237 Deeds, not Words.

238 Feathered Arrow.

239 Secret of a Life.

245 Caleb Stukeley.

253 The Iron Cousin.

264 Each for Himself.

272 Sir Roland Ashton.

287 The Greatest Plague of Life.

289 Sam Slick in England.

293 The Young Curate.

309 Matrimonial Shipwrecks.

3ro Hajji Baba of Ispahan.

333 The Two Baronets.

365 Will He Marry Her?

366 The Ex-Wife.

370 Emily Chester.

373 The Man of Fortune.

398 Black and Gold.

405 The First Lieutenant's Story.

410 Vidocq, the French Police Spy.

412 Shipwrecks and Disasters at Sea.

433 The Lamplighter.

Gerstaecker.

Lady Scott.

Lady Scott.

Gerstaecker. M. M. Bell.

Gerstaecker.

M. M. Bell. Samuel Phillips.

- Mrs. C. Clarke.

Gerstaecker.

Lady C. Long. Mayherv.

Sam Slick.

Anonymous.

Mrs. Maillard. Morier.

Lady Charlotte Bury.

Lang.

Lang.

Albany Fonblanque, Fun.

Capt. Patten Saunders.

Lady C. Long.

Miss Cummins.

\section{RAILWAY LIBRARY.}

Price 1s. 6d. each. (Postage 4x'.)

90 Godolphin.

96 The Hour and the Man.

I07 Zanoni.

I39 Northanger Abbey.

I5 I Peregrine Bunce.

185 Faint Heart ne'er Won Fair Lady.

I88 Chevalier de Maison Rouge.

I89 The Only Daughter.

213 Miriam May.

Lord Lytton. Martineau. Lord Lytton. Miss Austen. Theodore Hook.

D. Costello. Dumas. Gleig. Anonymous. 


\section{A Catalogue of Books}

\section{ROUTLEDGE'S CHEAP LITERATURE.}

\section{Price 1s. each.}

5 Life of Nelson.

8 Uncle Tom's Cabin.

Io Vicar of Wakefield.

31 Bundle of Crowquills.

46 Infidelity, its Cause and Cure.

II7 Female Life amongst the Mormons.

I 9 Hidden Path.

134 Ennui.

I7I Acting Proverbs.

Allen.

Mrs. Stowe.

Goldsmith.

Crowouill.

Nelson.

I9I A Lady's Captivity among Chinese Pirates.

205 A Sailor's Adventures.

206 Christian Names Explained.

207 The Pilgrim's Progress.

216 Balthazar; or, Science and Love.

226 Christmas Hamper.

Harland.

Edgeworth.

Harwood.

247 The Medical Student.

F. Loviot.

Gerstaecker.

N. Nichols.

Bunyan.

Balzac.

259 Love Tales, by Heyse.

265 Riddles and Jokes. 3rd Series.

266 Advertise: How? When? Where?

Mark Lemon. Albert Smith. 267 Adventures of a Sporting Dog.

268 Mrs. Jones' Evening Party.

269 Toddles' Highland Tour.

274 New Charades for the Drawing Room.

The Author of "A Trap to catch a Sunbeam."

275 Sam Spangles.

Sturling Coyne.

276 The Sparrowgrass Papers; or, Living in the Country.

278 A Sea-side Sensation.

Charles Ross.

279 Lives of Conservative Statesmen.

\section{Price 1s. 6d. each.}

148 Hills of the Shatemuc.

I 59 Flood and Field.

Miss Warner.

2I3 Rifle Volunteers.

Maxwell.

2I7 A Mounted Trooper's Adventures in the Australian Constabulary.

224 Echoes from the Backwoods.

236 Land and Sea Tales.

237 The War-Lock.

272 Life of Admiral Lord Dundonald.

W. Burrows. Sir R. Levinge. The Old Sailor. The Old Sailor. Allcn. 
Suitable for the Country and Sea-side.

\section{CHEA P L I T E R A T URE-Continued.}

\section{Price 2s. each.}

184 Forest Life in Norway and Sweden.

Newland.

I89 Marvels of Science.

Fullom.

195 Eminent Men and Popular Books.

Reprinted from the "Times."

230 Biography and Criticism. Reprinted from the "Times."

246 Sporting in both Hemispheres.

254 Horses and Hounds.

D'Ezes.

256 Life in China.

273 Life of Julius Cæsar.

277 A Cruise upon Wheels.

Scrutator.

Milne.

Archdeacon Williams.

C. A. Collins.

\section{BOOKS FOR THE COUNTRY.}

WITH NUMEROUS ILLUSTRATIONS.

Price 1s. each. (Postage 2d.)

I Angling, and Where to Go.

Robert Blakey.

2 Pigeons and Rabbits, in their Wild, Domestic, and Captive State, with Illustrations by Weir.

E. S. Delamer.

3 Shooting. Illustrated by Harrison Weir. Blakey.

4 The Sheep, our Domestic Breeds, and their Treatment. Illustrations by Harvey. W. C. L. Martin.

5 Flax and Hemp, their Culture and Manipulation. With Plates.

E. S. Delamer.

6 The Poultry Yard, comprising the Management of Fowls. Illustrated by $\mathrm{H}$. Weir.

E. Watts.

7 The Pig: how to Choose, Breed, Rear, Keep, and Cure.

Samuel Sidney.

Io The Horse. Illustrated by Wells. Cecil and Youatt.

II Bees : their Habits, Management, and Treatment, \&c.

12 Cage and Singing Birds. Rev. F. G. Wood.

13 Small Farms, and how they ought to be Managed.

I4 The Kitchen Garden. M. Doyle.

15 The Flower Garden. E. S. Delamer.

is The Common Objects of the Sea Shore. Boards. Illustrated with Coloured Plates. 


\section{A Catalogue of Books}

\section{BOOKS FOR THE COUNTRY-Continued.}

I9 The Common Objects of the Country. Boards. Illustrated with Coloured Plates.

2 I Woodlands, Heaths, and Hedges. Boards. Coleman. 22 British Ferns. Boards. Illustrated.

Thomas Moore, F.L.S.

23 Favourite Flowers : how to Grow them. A. G. Sutton.

24 British Butterflies. With 200 Illustrations. Boards.

27 Hints for Farmers.

Coleman.

Jritish Birds' Egrs and Nests. R. Scott Burn.
Su W. Coleman. Boards. Illustrations by W. S.
Rev. F $C$. Atkinson. 3 I Life of a Nag Horse. Fcap. 8vo. Boards. F. Taylor. 32 A Field Full of Wonders. Illustrated. Boards.

35 Food, Feeding, and Manure.

C. S. Cheltnam.

$$
\text { Price 1s. 6d. each. (Postage 2d.) }
$$

8 Cattle : their History and Various Breeds, Management, Treatment, and Disease. Revised by $W$. and $H$.

Raynbird.

20 Agricultural Chemistry.

25 The Rat. With Anecdotes.

W. C. L. Martin. sibson and Voelcker.

26 Dogs : their Management in Health and Disease With Illustrations.

29 British Timber Trees. Edward Mayhezv, M.R.C.V.S. Fohn Blenkarn.

33 Haunts of the Wild Flowers. Illustrated by Noel Humphreys. Boards.

34 Scientific Farming made Easy. Fcap. 8vo.

T. C. Fletcher, Analytical Chemist. 36 Horse-Taming, Horsemanship, and Hunting.

Rarey and Sidney.

Price 2s., in boards.

30 Wild Flowers : Where to Find and How to Know them. Illustrated. Spencer Thomson.

The Fine Edition, printed on superior paper, in a large type, with the Plates printed in Colours, fcap. 8vo., gilt.

$$
\text { Price 2s. 6d. each. (Postage 4d.) }
$$

I Common Objects of the Sea Shore.

2 Common Objects of the Country.

Wood. Wood. 
Suitable for the Country and Sea-side.

\section{BOOKS FOR THE COUNTRY-Continued.}

3 Woodlands, Heaths, and Hedges.

Coleman.

4 British Ferns and Allied Plants.

Moore.

5 British Butterflies.

6 British Birds' Eggs and Nests.

Coleman.

7 Wild Flowers.

Atkinson.

8 Common Objects of the Microscope.

9 Haunts of the Wild Flowers.

Spencer Thomson. Rev. F. G. Wood. Anne Pratt.

\section{ROUTLEDGE'S USEFUL LIBRARY.}

\section{INCLUDING THE SHILLING LAW BOOKS.}

In fcap. 8vo., cloth limp, or cloth boards. (Postage 2d.)

I Ladies' and Gentlemen's Letter Writer, containing Letters on the Simplest Matters of Life, with Applications for Situations, and a Copious Appendix of Forms of Address, \&c. .

* * The Ladies' and the Gentlemen's Letter Writer, in separate books, $6 d$. each.

6 Martin Doyle's Things Worth Knowing, a Book of General Practical Utility.

7 Landlord and Tenant (The Law of), with an Appendix of Useful Forms, Glossary of Law Terms.

W. A. Holdswort/.

9 History of France, from the Earliest Period to the Peace of Paris, 1856.

Amelia Edzuards.

ro Wills, Executors, and Administrators (The Law of), with Useful Forms.

W. A. Holdsworth.

II Rundell's Domestic Cookery, unabridged, with Illustrations.

W. T. Coleman, M.D.

13 Notes on Health : How to Preserve or Regain it.

I5 Common Objects of the Microscope, with 400 Illustrations by Tuffen West.

16 Law of Bankruptcy. Rev. F. G. Wood.

I7 One Thousand Hints for the Table, including Wines.

2I The County Court Guide, with Forms.

W. A. Holdsworth.

22 Geology for the Million, by M. Plues, edited by Rev. J. G. Wood.

23 Handy Book of Criminal Law.

W. A. Holdsworth. 


\section{A Catalogue of Books}

\section{USEFUL LIBRAR Y-Continued.}

24 Licensed Victualler's Handbook.

25 How to make Money.

27 Infant Management.

28 Practical Housekeeping.

29 A Manual of Weathercasts.

3o Commercial Letter-Writer.
IV. A. Holdsworth.

E. T. Freedlcy. Mis. Pedley. Mrs. Pedley.

Steinmetz.

P. L. Simmonds.

\section{Price Is. 6d. each.}

3 Landmarks of the History of England.

Rev. Fames White.

4 Landmarks of the History of Greece, with a Map. Rev. Fames While.

Price 2s.

26 Household Law.

A. Fonblanque.

\section{ROUTLEDGE'S SHILLING SONG BOOKS.}

EDITED AND COMPILED BY J. E. CARPENTER.

Fcap. 24mo., boards, with fancy covers. (Postage $2 d$.)

I Modern Song Book.

2 Popular Song Book.

3 New Universal Song Book.

4 Comic Song Book.
5 National Song Book.

6 Humorous Song Book.

7 New British Song Book.

8 New Standard Song Book.

\section{ROUTLEDGE'S SIXPENNY SONG BOOKS.}

\section{EDITED BY J. E. CARPENTER.}

Each $144 \mathrm{pp}$. fcap. 24mo, fancy covers. (Postage Id.)

I Fire-Side Song Book.

2 Home Songster.

3 British Song Book.

4 Songs for all Ages.

5 Select Songster.

6 Convivial Songster.

7 Merry Songs for Merry Meetings.

8 Funny Man's Song Book.
9 Fashionable Song Book. Io Drawing Room Song Book.

II Laughable Song Book.

I2 Sensation Songster.

I3 Everybody's Song Book.

14 Social Songster.

I5 Family Song Book.

I6 Amusing Songster. 
Suitable for the Country and Sea-side:

\section{ROUTLEDGE'S SIXPENNY HANDBOOKS.}

With Illustrations, and illustrated boarded covers. (Postage $\mathrm{I} d_{\text {. }}$ )

I Swimming and Skating, by the Author of the "Every Boy's Book."

2 Gymnastics.

3 Chess, with Diagrams.

4 Whist.

5. Billiards and Bagatelle.

6 Draughts and Backgammon.

7 Cricket.

8 The Cardplayer.

9 Rowing and Sailing.

Io Riding and Driving.

I I Archery, Fencing, and Broadsword.

I2 Conundrums.

I3 Manly Exercises : Boxing, Running, Training, \&c.

I5 Croquet, with Illustrations, Diagrams, \&c.

Rev. F. G. Wood. Pardon. Pardon. Pardon. Pardon.

Edmund Routledge. Pardon.

Edmund Routledge.

\section{R O UT LEDGE'S}

\section{SIXPENNY MINIATURE LIBRARY.}

Cloth, gilt edges. (Postage $\mathbf{I}$ d.)

I The Language of Flowers.

2 Etiquette for Gentlemen.

3 Etiquette for Ladies.
4 The Ball-Room Manual.

5 Etiquette of Courtship and Matrimony.

\section{ROUTLEDGE'S CHEAP COOKERY BOOKS.}

Soyer's Cookery for the People. Is.

Mrs. Rundell's Domestic Cookery. Is.

One Thousand Hints for the Table. I $s$.

Mrs. Rundell's Domestic Cookery. 2s.

The British Cookery Book. 3s. $6 d$. 


\section{A Catalogue of Books.}

\section{CHEAP COOKERY BOOKS-Continued.}

\section{Price 6d. each.}

A Plain Cookery for the Working Classes.

C. E. Francatelli.

The Cook's Own Book, in Question and Answer.

How to Cook Apples in roo Ways.

How to Cook Eggs in roo Ways.

Georgiana Hill.

Georgiana Hill.

How to Cook Rabbits in I24 Ways.

How to Cook Potatoes in roo Ways.

How to Cook Fish in roo Ways.

Georgiana Hill.

Georgiana Hill.

Georgiana Hill.

Georgiana Hill.

\section{ROUTLEDGE'S CHEAP DICTIONARIES.}

Well printed. Bound in cloth.

EDITED BY DR. NUTTALL.

Walker's Pronouncing Dictionary, containing all the New Words. Is.

Diamond Dictionary of the English Language, 640 pages, 25,000 words, clear type. Is.

Johnson's Dictionary, adapted to the Present State of English Literature. Is.

Johnson's Dictionary. Is.

Webster's Pronouncing Dictionary-Three Columns on a Page : 2,000 New Words; Scripture Names. Is. Johnson's Pocket Dictionary, with Walker's Pronunciation. Royal 32mo., $9 d$.

Johnson's Pocket Dictionary. Royal 32mo., $6 d$.

\section{CHEAP RECKONERS.}

Masters' Ready Reckoner, 17 th Edition, Edited by John Heaton, comprises Tables of Interest, Commission, Wages, Percentage and Profit, Time, Weights and Measures, Foreign Money, Decimal Tables, \&c. Is. The Miniature Ready Reckoner. $6 d$.

The Tradesman's Ready Calculator of Measurement for Masons, Plasterers, Painters, \&c. Shows the contents, in square yards, of any space measured in feet and inches. $6 d$.

\section{ROUTLEDGE'S PENNY TABLE BOOK.}

64 pages of Useful Information. 


\section{ROUTLEDGE'S USEFUL IIBRARY.}

In fcap. 8vo, cloth limp, or boards, price 1s. each, unless expressed.

A NEW LETTER-WRITER, for Ladies and Gentlemen: with applications for Situations, Forms of Address, Titles, \&c.

LANDMARKS OF THE HISTORY OF ENGLAND. By Rev. J. White, Author of "The Eighteen Christian Centuries." (1s. 6d.)

IANDMIARKS OF THE HISTORY OF GREECE. By the Rev. J. White, Author of "The Landmarks of England." (1s. 6d.)

THINGS WORTH KNOWING. By Martin Dorne.

LAW OF LANDIORD AND TENANT, with copious Useful Forms. By W. A. Holdsworth, Barrister-at-Law.

HISTORY OF FRANCE, from the Conquest of Gaul to the Peace of Paris, 1856. By Amelia B. Edwards.

THE LAW OF WILLS, EXECUTORS, AND ADMINISTRATORS, with Forms. By W. A. Holdsworth, Barristerat-Law.

RUNDELL'S DOMESTIC COOKERY.

NOTES ON HEALTH: How to Preserve or Regain it. By W. T. Coleman.

COMMION OBJECTS OF THE MICROSCOPE. By the Rev. J. G. Wood. With 400 Illustrations by TuFfeN West.

BANKRUPTCY (the New Law of) FOR POPULAR USE. By W. A. Holdsworti, Barrister-at-Law. Fcap. 8vo.

ONE THOUSAND HINTS FOR THE TABLE; with a few words upon Wines.

COUNTY COURT GUIDE (The). By W. A. Holdsworth. With Useful Forms, and Tables of Fees and Costs.

GEOLOGY FOR THe Million. By Margaret Plues. Edited by EDward Wood, F.G.S., F.R.S.L. With Tllustrations.

HANDY BOOK OF CRIMINAL LAW. By W. CAMPBELI Sleigh.

TIIE LICENSED VICTUALLERS' HANDY BOOK.

HOW TO MAKE MONEY. By E. T. FREEDLEY.

HOUSEHOLD laW. By Albany Fonblangue.

INFANT NURSING. By Mrs. Pedley.

PRACTICAL HOUSEKEEPING. By Mrs. Pedier.

A MANUAL OF WEATHERCASTS. By Andrew Sternmetz. THE COMMERCIAL LETTER WRITER. By W. $P$. Simmonds.

THE LAW OF CABS and OMNIBUSES. By W. T. Charley.

HOMIE BOOK OF DOMESTIC ECONOMY. By ANNE Bowman.

COMMION THINGS OF EVERY DAY RIFE. By ANNE Bowman.

LONDON : GEORGB ROUTLEDGE AND SONS. 


\section{BOOKS FOR THE COUNTRY.}

In Foolscap 8vo, Fancy Cloth Covers, with numerous Illustrations.

Price 1s. each (unless specified).

ANGLTNG, and WIIERE TO GO. By Robert Blatexy. PIGEONS and RABBITS. By E. S. DeLAMER. SHOOTING, in all its Varieties. By RoBert BLAKEx. SHEEP, their Diseases and Management. By W. C. L. MLArtiv. FLAX and HEMP, its Culture and Manipulation. THE POULTRY YARD. Edited and revised by E. WATTS. CATTLE. By Martin and Raynbird. (1s.6d.) THE HORSE; its History, Management, and Treatment. BEES; their Habits, Management, and Treatment. CAGE and SINGING BIRDS. By H. G. Adans. SMALL FARMS; their Management. By MarTin DorzE. THE KITCHEN GARDEN. By E. S. DELAMER. THE FLOWER GARDEN. By E. S. Delamer. RURAL ECONOMY. By Martin Doyle. FARM and GARDEN PRODUCE. By MARTIN DoYLz. COMMON OBJECTS of the SEA-SHORE. By WOOD. With Coloured Illustrations.

COMMON OBJECTS of the COUNTRY. By Wood. With Coloured Illustrations.

AGRICULTURAL CHEMISTRY. By ALFRED Srdson. OUR WOODLANDS, HEATHS, and HEDGES. BRITISH FERNS. By THOMAS MOORE, F.L.S. FAVOURITE FLOWERS; How to Grow Them. BRITISH BUTTERFLIES. By W. S. CoLemar. THE RAT, its History, and Destructive Character. (1s. 6d.) DOGS : their Management. By E. Maymew, M.R.C.V.S. (1s.6d.) HINTS for FARMERS. Bx R. Scott BURN.

BRITISH BIRDS' EGGS and NESTS. ATKINSON. BRITISH TIMBER TREES. By JoHn BlenKarN. (1s.6d.) WILD FLOWERS. By SPENCER Thomson. (2s.) LIFE of a NAG-HORSE. With Directions for Breaking and Training Horses, and Hints on Horsemanship. By F. TAYLOR. A FIELD FULL of WONDERS. HAUNTS of the WILD FLOWERS. (1s. 6d.) SCIENTIFIC FARMING MADE EASY. (1s.6d.) FOOD, FEEDING, and MANURE. By Alfred Sirson. HORSE-TAMING, HORSEMANSHIP, and HUNTING. By J. S. RAREY and SAMUEL SiDney. Illustrated. (1s.6d.) MR. MECHI'S FARM BALANCE-SHEETS, etc. THE PIG; How to Choose, Breed, Feed, Cut-up, and Cure. (1s. 6d)) CRAB, SHRIMP, and LOBSTER LORE. By W. B. LORD. Illustrated.

LONDON : GEORGE ROUTLEDGE AND BONS. 


\section{IOUTIEDGE'S HOUSEHOID MANUALS.}

Fcap. 8ro, price 6d. each, cloth limp.

THE COOK'S OWN BOOK: a Manual of Cookery for the Kitchen and the Cottage. By Georgiana Hrim. With Practical Illustrations.

THE GENTLEMAN'S LETTER- With applications for SituaWRITER. THE LADY'S LETTER-WRITER to Persons of Title, \&c.

VILLAGE MIUSEUM; or, How wo Gathered Profit with Pleasure. By Rev. G. T. Hoare.

IOW TO COOK and SERVE EGGS in 100 DIFFERENT Ways. By Georgiana Hill.

OW TO COOK RABBITS in 124 DIFFERENT WAYS. By Georgiana Hill.

ERY-DAY BLUNDERS in SPEAKING and WRITING.

W TO COOK POTATOES in 100 DIFFERENT WAYS, By Georgiana Hirl.

V TO COOK Fish. By Georgiara Hili.

I LOVER'S LETTER-WRITER.

IANKESTER on the CHOLERA.

IE NURSING.

W TO MAKE SOUP in 100 DIFFERENT WAYS. Dy Georginana Hitu.

IOW TO COOK ONIONS in 100 DIFFERENT WAYS. By Grorgtana Hill.

,OOD FOOD. By Dr. LANTESTER.

JINNERS and HOUSEKEEPING.

HOW TO PRESERVE FRUIT in 100 WAYS. By Georgiata HrLL.

'LEDGE'S RECIPE BOOK.

TO DRESS SALADS in 100 DIFFERENT WAYS. By gorgiana Hilu.

Y REMEDIES FOR COMMON COMPLAINTS.

TO COOK GAME in 100 WAYS. By Georgiana IIrL.

\section{ROUTIEDGE'S COOKERY BOOKS.}

iS COOKERY for the PEOPLE. (1s.)

UNDELL'S DOMESTIC COOKERY. (1s.)

HOUSAND HINTS for the TABLE. (1s.)

[N COOKERY for the WORKING CLASSES. By C. "RANCATElli. (6d.)

JNDELL'S DOMESTIC COOKERY. (2s.) ITISH COOKERY BOOK. Edited by J. WALSH. (3s. 6d.) COOKERY BOOK. By Arme Bowman. [Shortly.

IONDON: GEORGE ROUTLEDGE AND SONS. 

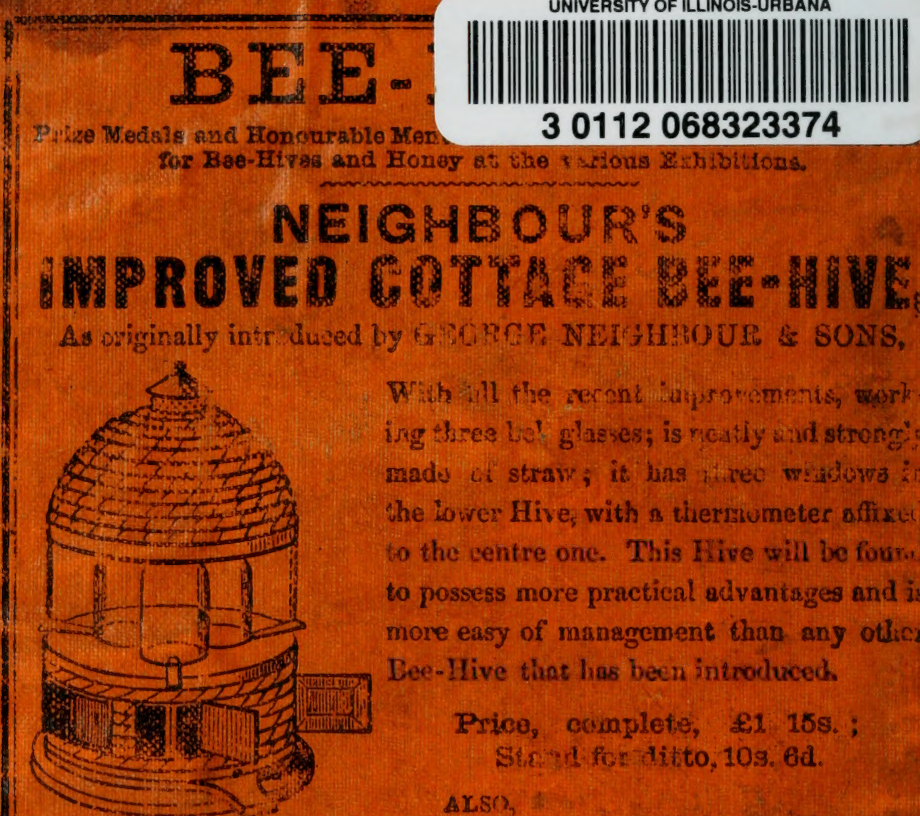

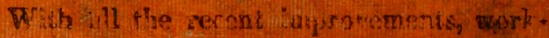
ing three lot glases; is reatly atad strong:? made at straw, it lias ativec wiudsowo in the lower Hive, with s thergiumeter affixth to the centre one. This Hive will be fowr. to possess more practical acivantages and is more easy of management than any otlicx Dee-Hive that has been introduced.

$$
\begin{gathered}
\text { Price, crimplete, \&1 } 15 \mathrm{~s} . \text {; } \\
\text { Sirend for dito, 109. 6d. }
\end{gathered}
$$

\section{$\triangle \mathrm{LSO}$}

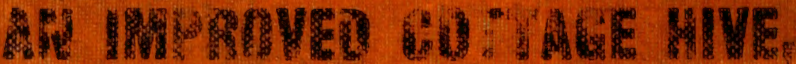

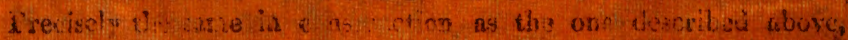

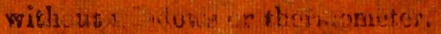

Rrice, wow jere, 21 8s:

\section{THE LIGURIAH OR TALIAL ALP RE.}

Baing much in reputes at the present time, and frequ. i ly inquired for we are in a position to suppiy strick of "he pure race, sarefutily fothes 8. as to travel by ruil with comparatively no risk of dawage. Furth. prorticulars seis on spplication.

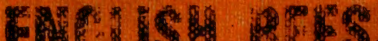 \\ C158)}

Stuckn snd Swarans may be obiais il tig bis:

\section{GEORGE NEIGHBOUR \& BOWS,}

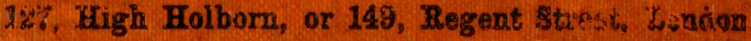

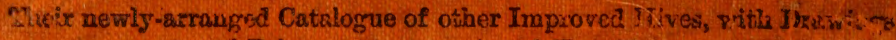
sad. Prices, sent on receipt of 'Tws, Stukinjs. 